\title{
Selective catalytic reduction of nitrogen oxides with ammonia over microporous zeolite catalysts
}

Peter N. R. Vennestrøm

Supervisors:

Prof. Avelino Corma

Dr. Arkady Kustov

\author{
PhD thesis \\ Submitted February 2014 \\ Instituto de Tecnología Química \\ Consejo Superior de Investigaciones Científicas \\ Universitat Politècnica de València
}

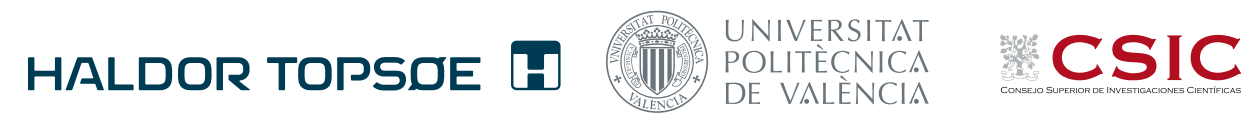


Copyright @: Peter N. R. Vennestrøm, 2014

Instituto de Tecnología Química

Consejo Superior de Investigaciones Científicas

Universitat Politècnica de València

Av. Naranjos s/n, E-46022 Valencia, Spain

Haldor Topsøe A/S

Nymøllevej 55, DK-2800 Kgs. Lyngby, Denmark

Print: J\&R Frydenberg A/S, København 


\section{Preface}

This thesis is submitted in candidacy for the $\mathrm{PhD}$ degree from the Politechnic University of Valencia (UPV). The work was carried out over the last three and a half years at the Danish company Haldor Topsøe A/S and at the Spanish Institute of Technical Chemistry, which is a joint research centre between UPV and the Consejo Superior de Investigaciones Científicas (CSIC), as part of the Industrial PhD programme funded by the Danish Ministry for Science, Technology and Innovation with Dr. Arkady Kustov (Haldor Topsøe A/S) and Prof. Avelino Corma (ITQ-CSIC) as supervisors. Additionally, Prof. Anker Degn Jensen from the Department of Chemical and Biochemical Engineering at the Technical University of Denmark partook in the project as third-party supervisor.

I would initially like to thank my university supervisor Prof. Avelino Corma for his guidance and support throughout the project and for giving me the opportunity to perform the Industrial $\mathrm{PhD}$ in his lab as well as always challenging my perspective in the field of zeolite science. I would also like to thank my company supervisor Dr. Arkady Kustov for his guidance and support throughout the project as well and especially for his ability to always hear me out and putting the research in a relevant applicable perspective. The project initially started with Assoc. Prof. Claus H. Christensen as supervisor whom I would like to thank for introducing me to zeolite science and research in general from a very early point in my career. Also, Dr. Marie Grill and Prof. Anker D. Jensen 
have been involved as co- and third-party supervisors, respectively, during the project and I would like to thank them for stepping in when needed and alway being thorough in their doings.

There are a great number of people I have had the pleasure to work with over the last three years who deserves a special thanks in the quest of understanding the mysteries of Cu-zeolites: Dr. Ton V. W. Janssens for showing me how to push catalytic testing and understanding therefrom to a high scientific level, Dr. Poul G. Moses for introducing me to DFT calculations and pushing my understanding at a molecular level, Dr. Anna Katerinopoulou and Ramchandra R. Tiruvalam for carrying out microscopy work and teaching me about the world in pixels, Dr. Anna M. P. Molina for helping me with XAFS interpretations, Dr. Lars F. Lundegaard for dedicating time - even to the point where I had to drive him home because his wife gave birth during beam time, Patricia Concepcion for helping me with XPS and infrared measurements and for answering my never ending questions, Alejandro Vidal for help with NMR (or "Erre-enneemme"), Dr. Pablo Beato for always great and enthusiastic discussions as well as establishing great social and scientific collaborations, Prof. Teresa Blasco and PhD student Marta Moreno for discussions and sharing of NMR and EPR results, the Italian and Danish connection: Prof. Carlo Lamberti and Prof. Silvia Bordiga together with PhD student Filippo Giordanino and Assoc. Prof. Susanne Mossin for great collaboration on characterization and very insightful discussions.

A special thanks also goes to Gitte Madsen for invaluable help with catalytic testing and Anni Stahl for small talk and great help with preparations when time was running short. I would also like to thank all the wonderful people in synthesis lab "numero uno" - especially Vicente, Raquel and Amparro.

My warmest thanks also goes to my family, who despite many challenges over the last years have been very understanding and supporting and my most loving thanks to Cathrine Friberg for her support to carry out a $\mathrm{PhD}$ project half the time in Spain when she was in Denmark, her wonderful distractedness and extensive love. 


\section{Abstract}

Legislation to remove nitrogen oxides $\left(\mathrm{NO}_{\mathrm{x}}\right)$ and other pollutants is becoming increasingly more stringent in every part of the world. One of the largest contributions comes from mobile sources, where $\mathrm{NO}_{\mathrm{x}}$ and soot particles are generated during combustion. In order to remove these harmful compounds catalytic solutions are needed and especially zeolite-based systems are considered amongst the most promising candidates for selective catalytic reduction of $\mathrm{NO}_{\mathrm{x}}$ using ammonia as reductant $\left(\mathrm{NH}_{3}-\mathrm{SCR}\right)$ in diesel exhaust after treatment systems.

This thesis explores the use of copper exchanged zeolites in the $\mathrm{NH}_{3}$-SCR reaction. Zeolites are crystalline microporous aluminosilicates where many framework topologies have already been discovered. For this reason several known frameworks were initially used to screen for activity- and deactivation-structurerelationships. More specifically similar amounts of copper was introduced into zeolites of the type MFI, BEA, FAU, MOR, FER, CHA, SZR and LEV with similar aluminum contents. It was shown that zeolites with three-dimensional pore systems gave the highest $\mathrm{NO}_{\mathrm{x}}$ conversion and that the activity of zeolites with small pores were confirmed to be more stable under hydrothermal conditions. Additionally, it was shown that pore size and dimensionality of the pore system dictate the formation of unwanted $\mathrm{N}_{2} \mathrm{O}$ during $\mathrm{NH}_{3}$-SCR so that large pores and dimensionality enhance $\mathrm{N}_{2} \mathrm{O}$ formation.

Deactivation by unburnt hydrocarbons (HCs) can also be detrimental to the 
use of zeolites. By using zeolites (BEA, MFI and CHA) a window-size effect was shown to dictate the degree of $\mathrm{HC}$ influence on the $\mathrm{NH}_{3}-\mathrm{SCR}$ performance. In this way the severity of $\mathrm{HCs}$ followed the order $\mathrm{Cu}-\mathrm{BEA}>\mathrm{Cu}-\mathrm{MFI}>\mathrm{Cu}-$ $\mathrm{CHA}$. To better understand the influence of $\mathrm{HCs}$ on small pore zeolites $\mathrm{Cu}$ SSZ-13 and Cu-SAPO-34 was chosen to investigate the effect of framework polarity. Adsorption experiments showed that similar amounts of propylene (and products thereof) are adsorbed on Cu-SSZ-13 and Cu-SAPO-34 up to $250{ }^{\circ} \mathrm{C}$. However, above this temperature $\mathrm{Cu}-\mathrm{SAPO}-34$ showed less propylene uptake than the $\mathrm{Cu}-\mathrm{SSZ}-13$, which was ascribed to the differences in chemical composition of the two catalyst materials leading to different framework polarities. The influence of propylene poisoning on the catalytic performance was tested by co-feeding propylene during the $\mathrm{NH}_{3}-\mathrm{SCR}$ reaction at 250 and $300{ }^{\circ} \mathrm{C}$ that showed a higher resistance for $\mathrm{Cu}-\mathrm{SAPO}-34$ towards hydrocarbon poisoning at higher temperatures than did the $\mathrm{Cu}$-SSZ-13 as expected from the differences in propylene uptake. Despite the differences in $\mathrm{HC}$ resistance all catalytic activity of all materials investigated could be recovered by heating to high temperatures e.g. $550{ }^{\circ} \mathrm{C}$ that are experienced under automotive operating conditions.

Small-pore zeotype $\mathrm{Cu}-\mathrm{SAPO}-34$ is an interesting candidate for future $\mathrm{NH}_{3}$ SCR purposes, because it exhibits high hydrothermal stability and industrial production is already available. Therefore, its use was investigated and it was found that an activation at $750{ }^{\circ} \mathrm{C}$ is needed in order to exploit this material's full potential. The activation was shown to involve migration of $\mathrm{Cu}$ from the near-surface region into the crystals. The migration of copper was also modeled by DFT calculations whereupon further improvements to the activation atmosphere were discovered and verified experimentally. Best results were obtained when water was added to the activation atmosphere. In fact, the activity per copper atom at low temperatures $\left(180^{\circ} \mathrm{C}\right)$ in properly activated $\mathrm{Cu}-\mathrm{SAPO}-34$ was shown to be approximately double that of the aluminosilicate counter-part $\mathrm{Cu}-\mathrm{SSZ}-13$, which makes Cu-SAPO-34 a promising candidate for industrial applications.

To better understand the hydrothermal deactivation mechanism of copper based zeolites, Cu-ZSM-5 and Cu-IM-5 were lastly used as model materials. These materials exhibited very similar catalytic activity in the fresh state, but because the aluminum is more stable in the IM-5 structure the influence of framework stability and cation migration could be decoupled by use of various characterization techniques. Especially the migration of copper ions from $\mathrm{CuO}$ into zeolite ion exchange positions was found to be facile under typical SCR conditions. 
Based on the findings a deactivation mechanism was suggested to rationalize the results including reversible copper migration and irreversible formation of a $\mathrm{Cu}-\mathrm{Al}$ phase related to the aluminum stability in the framework. Furthermore, this mechanism could also explain the differences in deactivation iron and copper exchanged zeolites under hydrothermal conditions. 
La legislación para eliminar los óxidos de nitrógeno $\left(\mathrm{NO}_{\mathrm{x}}\right)$ y otros contaminantes es cada vez más estricta en todo el mundo. Las fuentes móviles son uno de los mayores contribuyentes generando emisiones de $\mathrm{NO}_{\mathrm{x}}$ y material particulado durante la combustión. Con el fin de eliminar estos compuestos nocivos se necesitan soluciones catalíticas, y son especialmente los sistemas basados en zeolitas, los candidatos más prometedores para la reducción catalítica selectiva de NOx. Estos sistemas emplean amoníaco como agente reductor en sistemas de post-tratamiento de los gases de escape en motores diésel.

Esta tesis explora el uso de zeolitas intercambiadas con cobre en la reducción catalítica selectiva de $\mathrm{NO}_{\mathrm{x}}$ mediante el uso de $\mathrm{NH}_{3}\left(\mathrm{NH}_{3}-\mathrm{SCR}\right)$. Las zeolitas son aluminosilicatos cristalinos microporosos con distintas topologías, muchas de las cuales ya han sido descubiertas. Por esta razón, distintas topologías ya conocidas se emplearon inicialmente para establecer la relación entre la actividad, la desactivación y la estructura de las mismas. Concretamente, cantidades similares de cobre se introdujeron en zeolitas tipo MFI, BEA, FAU, MOR, FER, CHA, SZR y LEV, cuyo contenido en aluminio era similar. Se demostró que las zeolitas con sistemas de poros tridimensionales eras más activas con respecto a la conversión de $\mathrm{NO}_{\mathrm{x}}$, mientras que la actividad de las zeolitas con poros más pequeños resultó más estable bajo condiciones hidrotermales. Además, se demostró que el tamaño de poro y la dimensionalidad del sistema de poros dictan la formación de $\mathrm{N}_{2} \mathrm{O}$ no deseado durante el proceso SCR con amoníaco, 
de manera que grandes poros y un mayor grado de dimensionalidad mejoran la formación de $\mathrm{N}_{2} \mathrm{O}$.

La desactivación de las zeolitas por parte de hidrocarburos no quemados (HCs) también puede ser perjudicial para su uso. La influencia de los HCs en el rendimiento del sistema $\mathrm{NH}_{3}$-SCR fue estudiada con las zeolitas BEA, MFI y CHA, mostrando un efecto del tamaño de la ventana. De esta manera, el grado de desactivación de los $\mathrm{HCs}$ siguió el siguiente orden $\mathrm{Cu}-\mathrm{BEA}>\mathrm{Cu}-\mathrm{MFI}>\mathrm{Cu}-$ CHA. Con el objetivo de entender mejor la influencia de los HCs en zeolitas de poro pequeño, Cu-SSZ-13 y Cu-SAPO-34, se eligieron para investigar el efecto de la polaridad en su estructura. Experimentos de adsorción mostraron que cantidades similares de propileno (y sus productos) son adsorbidas en $\mathrm{Cu}-\mathrm{SSZ}$ 13 y Cu-SAPO-34 hasta $250{ }^{\circ} \mathrm{C}$. Sin embargo, por encima de esa temperatura Cu-SAPO-34 mostró una menor capacidad de adsorción que Cu-SSZ-13. Este hecho se atribuyó a las diferencias en la composición química de los dos catalizadores, lo que conlleva diferentes polaridades en su estructura. La influencia del envenenamiento de las zeolitas por propileno en el rendimiento catalítico se estudió mediante la co-alimentación de propileno durante la reacción de $\mathrm{NH}_{3}$ SCR entre 250 y $300{ }^{\circ} \mathrm{C}$. Los resultados mostraron una mayor resistencia para $\mathrm{Cu}-\mathrm{SAPO}-34$ con respecto al envenenamiento por hidrocarburos a altas temperaturas que para Cu-SSZ-13, tal y como se esperaba a partir de las diferencias en la adsorción de propileno. A pesar de la distinta resistencia al envenenamiento por HCs de las zeolitas investigadas, la actividad catalítica de todas ellas se recuperó tras un tratamiento a altas temperaturas, en torno a $550{ }^{\circ} \mathrm{C}$, que son perfectamente alcanzables en condiciones de funcionamiento de los automóviles.

La zeolita de poros pequeños Cu-SAPO-34 es un material interesante para su futura aplicación en sistemas $\mathrm{NH}_{3}$-SCR puesto que exhibe una alta estabilidad hidrotermal y su producción industrial ya se encuentra disponible. Se investigó su uso y se determinó que una activación a $750{ }^{\circ} \mathrm{C}$ es necesaria a fin de explotar todo el potencial de este material. Se probó que la activación involucra la migración de $\mathrm{Cu}$ de la región cercana a la superficie hacia los cristales. Dicha migración también se modeló mediante cálculos DFT, contribuyendo al descubrimiento de nuevas mejoras en la atmósfera de activación que posteriormente fueron verificadas experimentalmente. Los mejores resultados se obtuvieron cuando se incluyó agua en la atmósfera de activación. De hecho, la actividad por átomo de cobre a bajas temperaturas $\left(180{ }^{\circ} \mathrm{C}\right)$ en $\mathrm{Cu}-\mathrm{SAPO}-34$ activado resultó ser aproximadamente el doble que la actividad de su homólogo, Cu-SSZ-13, confirmando que la zeolita Cu-SAPO-34 es un candidato muy 
prometedor para aplicaciones industriales.

Con el fin de comprender mejor el mecanismo de desactivación hidrotermal de zeolitas basadas en cobre, Cu-ZSM-5 y Cu-IM-5, fueron empleadas como materiales modelo. Estos materiales exhibieron una actividad catalítica muy similar en estado fresco, sin embargo, debido a que el aluminio es más estable en la estructura IM-5, la influencia de la estabilidad de esta topología y la migración de cationes pudieron ser separadas gracias al uso de diversas técnicas de caracterización. Particularmente, se observó que la migración de los iones de cobre de $\mathrm{CuO}$ hacia las posiciones de la zeolita de intercambio iónico era facilitada en las condiciones típicas de SCR.

De acuerdo con los hallazgos, se propuso un mecanismo de desactivación para razonar los resultados, teniendo en cuenta la migración reversible de cobre y la formación irreversible de una fase $\mathrm{Cu}-\mathrm{Al}$, relacionada con la estabilidad del aluminio en la estructura. Además, este mecanismo también podría explicar las diferencias en la desactivación de zeolitas intercambiadas con hierro y cobre bajo condiciones hidrotermales. 
Resum en Valencià

La legislació per a controlar les emissions dels òxids de nitrogen $\left(\mathrm{NO}_{\mathrm{x}}\right)$ i d'altres contaminants és cada vegada més estricta en tot el món. Els focus mòbils de combustió són uns dels principals emissors de $\mathrm{NO}_{\mathrm{x}}$ i de partícules. Per a eliminar aquests compostos nocius són necessàries solucions catalítiques i entre elles l'ús de zeolites per a la reducció catalítica selectiva de $\mathrm{NO}_{\mathrm{x}}$ és una de les més prometedores. Aquest es un sistema de post-tractament dels gasos emesos pel tub d'escapament dels motors dièsel i es basa en l'ús de l'amoníac com a agent reductor dels $\mathrm{NO}_{\mathrm{x}}$ formats.

Aquesta tesi explora l'ús de zeolites intercanviades amb coure com a catalitzadors per a la reducció catalítica selectiva de $\mathrm{NO}_{\mathrm{x}}$ amb $\mathrm{NH}_{3}\left(\mathrm{NH}_{3}-\mathrm{SCR}\right)$. Les zeolites són aluminosilicats cristal-lins microporosos amb diferents topologies. Per aquesta raó diferents topologies conegudes es varen utilitzar inicialment per a establir la relació entre l'activitat del catalitzador, la seva possible desactivació i l'estructura de les zeolites. En concret, quantitats similars de coure es varen introduir en zeolites tipus MFI, BEA, FAU, MOR, FER, CHA, SZR i LEV, les quals tenen un contingut similar d'alumini. Es va demostrar que les zeolites amb sistemes de porus tridimensionals eren més actives, respecte a la conversió de $\mathrm{NO}_{\mathrm{x}}$, però les zeolites amb porus més menuts eren més estables en condicions hidrotèrmiques. A més es va demostrar que la grandària del porus i la dimensionalitat del sistema de porus és el que dicta la formació de $\mathrm{N}_{2} \mathrm{O}$, que és un subproducte no desitjat en aquesta reacció, de forma que porus grans i 
major grau de dimensionalitat afavoreixen la formació de $\mathrm{N}_{2} \mathrm{O}$.

La desactivació de les zeolites per hidrocarburs no cremats (HCs) també pot ser perjudicial per al seu ús. La influència dels HCs en el rendiment del sistema $\mathrm{NH}_{3}$-SCR fou estudiada amb les zeolites BEA, MFI i CHA. Es va veure que hi ha una relació entre la grandària de finestra de les zeolites i la desactivació pels $\mathrm{HCs}$, de forma que la desactivació segueix el següent ordre $\mathrm{Cu}-\mathrm{BEA}>\mathrm{Cu}-$ $\mathrm{MFI}>\mathrm{Cu}-\mathrm{CHA}$. Amb l'objectiu d'entendre millor la influència dels HCs en les zeolites de porus menut, les zeolites $\mathrm{Cu}$-SSZ-13 i Cu-SAPO-34 es varen triar per a investigar l'efecte de la polaritat de ret. Els experiments d'adsorció varen mostrar que quantitats similars de propilè (i dels seus productes) són adsorbides en Cu-SSZ-13 i Cu-SAPO-34 fins a $250{ }^{\circ} \mathrm{C}$. No obstant això, per damunt d'aquesta temperatura Cu-SAPO-34 va mostrar una menor capacitat d'adsorció que Cu-SSZ-13. Aquest fet es pot relacionar amb la diferent composició química dels catalitzadors, que produeix diferents polaritats de ret. La influència de l'enverinament de les zeolites per propilè en el rendiment catalític es va estudiar mitjançant la co-alimentació de propilè en la reacció de $\mathrm{NH}_{3}-\mathrm{SCR}$ entre 250 i $300{ }^{\circ} \mathrm{C}$. Els resultats varen mostrar una major resistència del $\mathrm{Cu}-\mathrm{SAPO}-34$ front a l'enverinament per hidrocarburs a altes temperatures, tal i como calia esperar a partir del resultats obtinguts en l'adsorció de propilè. En qualsevol cas, l'activitat catalítica dels diferents catalitzadors es recupera a altes temperatures, al voltant de $550{ }^{\circ} \mathrm{C}$, que és una temperatura que es sol aconseguir en les condicions de funcionament del automòbils.

La zeolita de porus menut Cu-SAPO-34 és un material interesant per a futures aplicacions en sistemes $\mathrm{NH}_{3}$-SCR ja que presenta una elevada estabilitat hidrotèrmica i es produïda industrialment. Es va investigar el seu ús i es va determinar que una activació a $750{ }^{\circ} \mathrm{C}$ es precisa per a explotar tot el potencial d'aquest material. Es va comprovar que l'activació implica la migració del $\mathrm{Cu}$ des de la regió pròxima a la superfície fins als cristalls. Aquesta migració es va modelar mitjançant càlculs DFT, contribuint al descobriment de noves millores en les condicions d'activació que a posteriori varen ser verificades experimentalment. Els millor resultats es varen obtenir quan es va introduir aigua en l'atmosfera d'activació i l'activitat per àtom de coure a baixes temperatures $\left(180{ }^{\circ} \mathrm{C}\right)$ en $\mathrm{Cu}-\mathrm{SAPO}-34$ activada d'aquesta forma va ser el doble que l'activitat del seu homòleg Cu-SSZ-13, confirmant que la zeolita Cu-SAPO-34 es un candidat molt prometedor per a aplicacions industrials.

Amb la finalitat de comprendre millor el mecanisme de desactivació hidrotèr- 
mica de les zeolites de coure, es varen utilitzar les zeolites Cu-ZSM-5 i Cu-IM5 com a material model. Aquests materials tenen una activitat catalítica inicial molt semblant, però com l'alumini és més estable en la estructura IM-5, la influència de la estabilitat de ret i la migració catiònica pot esser separada utilitzant diverses tècniques de caracterització. Es va observar que la migració dels ions coure des de $\mathrm{CuO}$ a les posicions d'intercanvi de la zeolita és fàcil en les condicions típiques de SCR.

Basant-se en aquests descobriments es va proposar un mecanisme de desactivació que inclou la migració reversible del coure i la formació de la fase $\mathrm{Cu}-\mathrm{Al}$ que afecta a l'estabilitat de l'alumini en la ret. A més a més aquest mecanisme pot explicar les diferències en la desactivació de les zeolites intercanviades amb ferro i coure en condicions hidrotèrmiques. 
1 Introduction $\quad 1$

1.1 Motivation ......................... 1

1.2 Objectives and outline of the thesis . . . . . . . . . 8

2 Screening of various zeolite framework topologies for $\mathrm{NH}_{3}$-SCR 10

2.1 Introduction . . . . . . . . . . . . . . . . . 10

2.2 Experimental . . . . . . . . . . . . . . . . . 11

2.3 Results and Discussion . . . . . . . . . . . . . . . . 13

2.3.1 Influence of zeolite framework topology on catalytic performance . . . . . . . . . . . . . . 14

2.3.2 Influence of zeolite framework topology on hydrothermal stability . . . . . . . . . . . . . 17

2.3.3 Formation of $\mathrm{N}_{2} \mathrm{O}$ depending on zeolite framework topology 18

2.4 Summary and Conclusions . . . . . . . . . . . . . . . . 21

2.5 Future work . . . . . . . . . . . . . . . . 22

3 Hydrocarbon resistance of $\mathrm{Cu}$-zeolites in the $\mathrm{NH}_{3}-\mathrm{SCR}$ reaction 23

3.1 Introduction . . . . . . . . . . . . . . . . 23

3.2 Experimental . . . . . . . . . . . . . . . . . 25

3.3 Results and Discussion . . . . . . . . . . . . . . . . . . 26 
3.3.1 Effect of window size . . . . . . . . . . . . . 27

3.3.2 Poisoning of small-pore catalysts: effect of framework polarity . . . . . . . . . . . . . . . . . 29

3.4 Summary and Conclusions . . . . . . . . . . . . . . . . . . . . . . . . . . . . . . . . . 33

3.5 Future work . . . . . . . . . . . . . . . 34

4 Thermal activation of Cu-SAPO-34: migration of $\mathrm{Cu}$-ions and influence on $\mathrm{NH}_{3}$-SCR performance $\quad 35$

4.1 Introduction . . . . . . . . . . . . . . . . . . 35

4.2 Experimental . . . . . . . . . . . . . . . . . . . . . . . . . . . 37

4.3 Results and discussion . . . . . . . . . . . . . . . . . . . . . . . . . . . . . . . 48

4.4 Summary and Conclusions . . . . . . . . . . . . . . . 47

5 Influence of the atmosphere on Cu-SAPO-34 activation and its performance in the $\mathrm{NH}_{3}-\mathrm{SCR}$ reaction 49

5.1 Introduction . . . . . . . . . . . . . . . . . . 49

5.2 Experimental . . . . . . . . . . . . . . . 50

5.2 .1 Materials .................... 50

5.2 .2 Characterization and catalytic testing . . . . . . . . 50

5.2 .3 DFT calculations . . . . . . . . . . . . . . . 51

5.3 Results and Discussion . . . . . . . . . . . . . . . . . 52

5.3.1 Determination of the amount of $\mathrm{Si}$ without other $\mathrm{Si}$ as next-nearest neighbors . . . . . . . . . . . 52

5.3.2 Migration studies in SAPO-34 by DFT calculations . . . 55

5.3.3 Catalytic evaluation of $\mathrm{Cu}-\mathrm{SAPO}-34$ after activation in different atmospheres . . . . . . . . . . . 66

5.4 Summary and Conclusions . . . . . . . . . . . . . . . 66

6 Hydrothermal deactivation of Cu-ZSM-5 and Cu-IM-5 zeolites $\begin{array}{lr}\text { and impact on } \mathrm{NH}_{3} \text {-SCR performance } & 68\end{array}$

6.1 Introduction . . . . . . . . . . . . . . . . . . . . 68

6.2 Experimental . . . . . . . . . . . . . . . . . 70

6.3 Results and Discussion . . . . . . . . . . . . . . . . 73

6.4 Summary and Conclusions . . . . . . . . . . . . . . . . . 90

7 Summary, Conclusions and Perspectives 92

7.1 Summary and Conclusions . . . . . . . . . . . . . . . . . . 92

7.2 Perspectives . . . . . . . . . . . . . . . . . . 95 
A Publications

A 


\section{CHAPTER 1}

\section{Introduction}

\subsection{Motivation}

Release of nitrogen oxides $\left(\mathrm{NO}_{\mathrm{x}}, \mathrm{x}=1,2\right)$ into the atmosphere is a major cause for air pollution associated with several human health issues and affects the environment in general. As an example even short term exposure to $\mathrm{NO}_{2}$ is known to give adverse respiratory effects including decreased lung function and airway inflammation.[1, 2] Long term exposure have also been linked to people with asthma and bronchitis, who are particularly affected.[1] $\mathrm{NO}_{\mathrm{x}}$ eventually, but inevitable, also forms nitric acid when exposed to atmospheric moisture and is furthermore a precursor for photochemical smog and engaged in natural and human made ozone production. $[3,4]$

The primary source for $\mathrm{NO}_{\mathrm{x}}$ production is by thermal formation when nitrogen and oxygen reacts at higher temperatures. $\mathrm{NO}_{\mathrm{x}}$ is therefore an unavoidable byproduct in combustion processes whenever atmospheric air is used as the oxygen source in mobile and stationary applications. For the above-mentioned reasons $\mathrm{NO}_{\mathrm{x}}$ emissions should be limited. They should be limited, not only because of the immediate human and atmospheric consequences, but also in order to avoid long-term environmental impacts. 


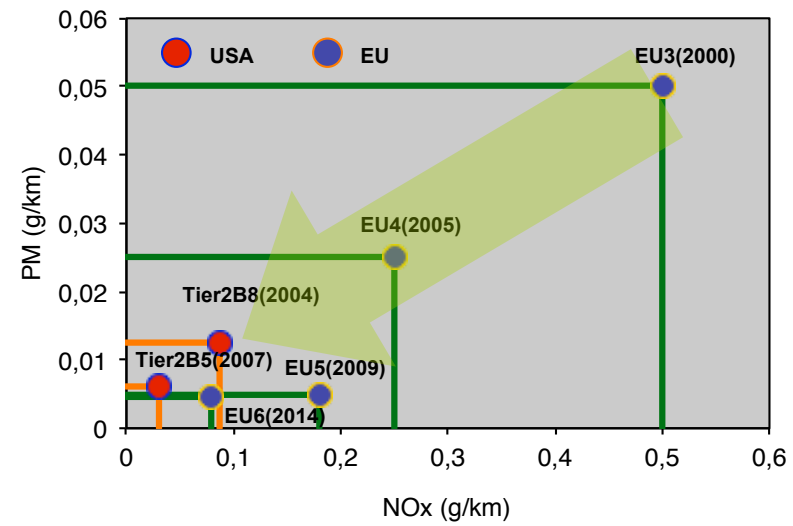

Figure 1.1: Emission standards for $\mathrm{NO}_{\mathrm{x}}$ and particulate matter in the European Union and United States for light duty vehicles. The year of implementation is given in parenthesis. Data were adopted from [5]

Of special interest in this project is the removal of $\mathrm{NO}_{\mathrm{x}}$ from mobile applications and in particular from diesel engines. The necessity to limit vehicle emissions began with air pollution regulations, of $\mathrm{NO}_{\mathrm{x}}$ among others, by the United States in 1970 and with several later amendments.[6] Since then legislation in all industrialized countries has limited permitted levels of emissions from mobile sources and is becoming increasingly more stringent with the development of technology. $\mathrm{NO}_{\mathrm{x}}$ is typically regulated together with particulate matter, which is another air pollutant and especially related to smog and human carcinogenic effects. As an example of legislation development current and future European and US limits are shown in Figure 1.1. Early emission standards allowed diesel engine manufacturers to tune the engine or recycle the exhaust in order to meet legislation at the expense of fuel economy. However economic and environmental concerns require improved fuel economy and simultaneously the legislation is becoming increasingly stringent as indicated by the arrow in Figure 1.1. Consequently more effective methods to meet legislation are required.

While the invention of the "three-way-catalyst" lead to efficient removal of $\mathrm{NO}_{\mathrm{x}}$ from the exhaust of gasoline engines, this method is not applicable to the ex- 
haust from diesel engines, because they operate under lean conditions with excess oxygen. An efficient method to remove $\mathrm{NO}_{\mathrm{x}}$ from diesel exhaust is by selective catalytic reduction (SCR). The reducing agent used practically is ammonia and typically injected into the system before the catalyst as urea, which decompose to form ammonia and carbon dioxide. The overall SCR reactions that takes place with ammonia are:

$$
\begin{aligned}
& 4 \mathrm{NO}+4 \mathrm{NH}_{3}+\mathrm{O}_{2} \longrightarrow 4 \mathrm{~N}_{2}+6 \mathrm{H}_{2} \mathrm{O} \\
& \mathrm{NO}+\mathrm{NO}_{2}+2 \mathrm{NH}_{3} \longrightarrow 2 \mathrm{~N}_{2}+3 \mathrm{H}_{2} \mathrm{O} \\
& 8 \mathrm{NH}_{3}+6 \mathrm{NO}_{2} \longrightarrow 7 \mathrm{~N}_{2}+12 \mathrm{H}_{2} \mathrm{O}
\end{aligned}
$$

(Standard SCR Reaction)

(Fast SCR Reaction)

$\left(\mathrm{NO}_{2}\right.$ SCR Reaction)

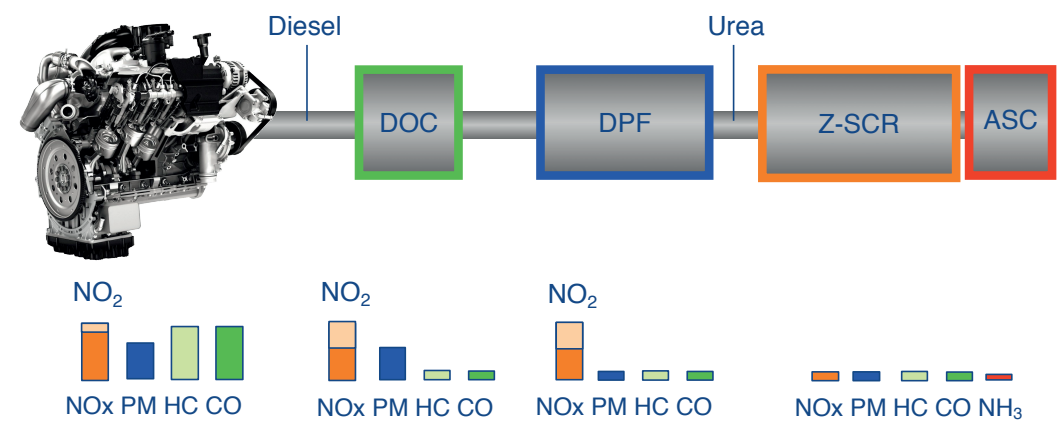

Figure 1.2: Schematic representation of diesel exhaust system to meet EURO VI emission standards $($ DOC $=$ Diesel Oxidation Catalyst, DPF $=$ Diesel Particulate Filter, Z-SCR = Zeolite Selective Catalytic Reduction catalyst and $\mathrm{ASC}=$ Ammonia Slip Catalyst

In this way harmless nitrogen and water is produced. The formation of $\mathrm{N}_{2} \mathrm{O}$ from $\mathrm{NH}_{3}$ with $\mathrm{O}_{2}$, $\mathrm{NO}$ or $\mathrm{NO}_{2}$ is considered the biggest by product, and can in some cases limit the overall selectivity. SCR technology, based on the above reactions, has been used for decades for stationary applications and to some extent recently for mobile applications. Traditional SCR catalysts are based on $\mathrm{V}_{2} \mathrm{O}_{5}$ together with $\mathrm{WO}_{3}$ supported on $\mathrm{TiO}_{2}$ support. Vanadium based catalysts however possess a number of drawbacks and limitations: i) poisonous vanadium species can be released into the environment during operation at higher temperatures and for this reason vanadium catalysts are banned in certain regions of the world (e.g. United States and Japan), ii) the selectivity at higher temperatures is not 
always sufficient due to unselective ammonia oxidation and iii) thermal stability of vanadium based catalysts is poor above $550^{\circ} \mathrm{C}$, which may be required during active regenerations of an upstream diesel particulate filter. In Figure $1.2 \mathrm{a}$ schematic representation of a typical exhaust system needed to meet EURO VI emission standards is shown. As seen, the system consists of many components where each play a significant role in meeting required emission reductions.
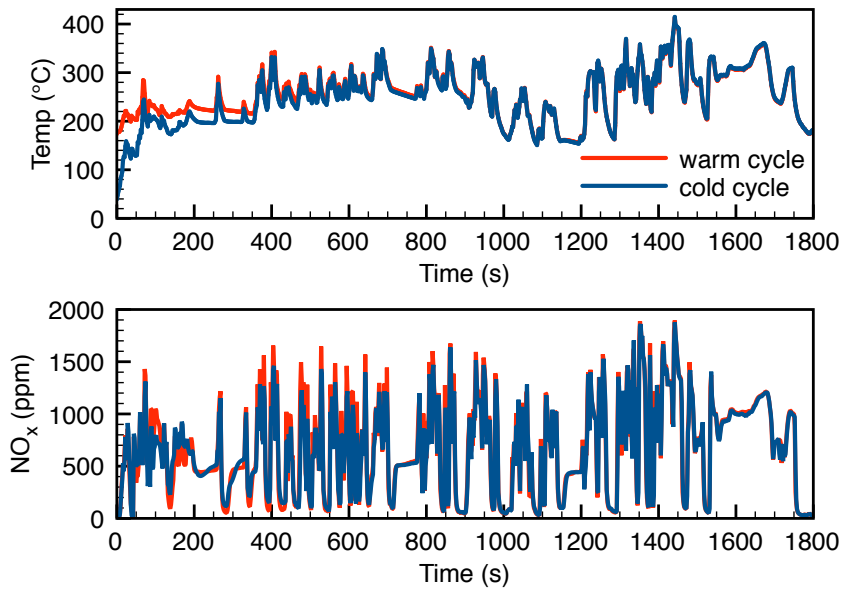

Figure 1.3: Temperature and $\mathrm{NO}_{\mathrm{x}}$ coming out of the engine during a WHTC test cycle on a light duty engine during a cold and a warm cycle

Exhaust leaving the diesel engine first meets a diesel oxidation catalyst. The purpose of this catalyst is to oxidize any unburnt hydrocarbons and carbon monoxide and by direct injection of diesel to raise the temperature in the exhaust system if needed. It furthermore aids in oxidizing some of the NO to $\mathrm{NO}_{2}$, which improves the $\mathrm{NO}_{\mathrm{x}}$ removal by facilitating the fast SCR reaction. Secondly, the exhaust is passed through a diesel particulate filter that has the sole purpose of removing particulate matter. When the soot particles are collected on the filter a pressure drop builds up and regeneration of the filter, by combustion of the soot parcels, becomes necessary. For this reason catalytic activity is typically incorporated in the filter also, but temperature excursion (typically temperatures above $650{ }^{\circ} \mathrm{C}$ ) may be needed during active regenerations. The last segment in the exhaust treatment is responsible for removing 
the $\mathrm{NO}_{\mathrm{x}}$. Typically an SCR catalyst is used in combination with an ammonia slip catalyst. This combination is typically used because the $\mathrm{NO}_{\mathrm{x}}$ conversion is limited by the amount of ammonia. Addition of a small surplus of ammonia (from urea addition and decomposition) therefore ensures high $\mathrm{NO}_{\mathrm{x}}$ conversion, and is afterwards removed by the slip catalyst.

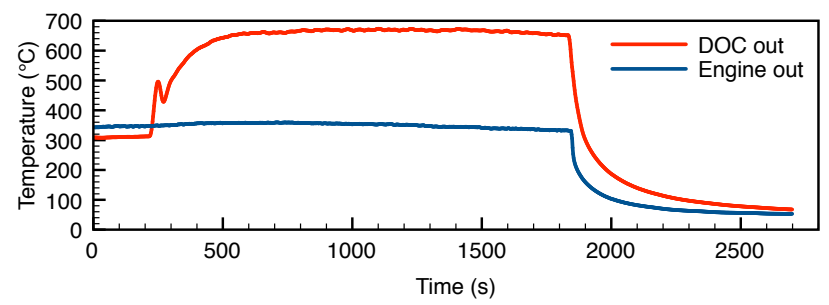

Figure 1.4: Typical active regeneration of a combined Diesel Particulate Filter with SCR functionality (DPF/Z-SCR), showing the temperature coming out of the engine and out of the Diesel Oxidation Catalyst (DOC)

Much industrial effort is being put into combinations of the different catalytic components shown in Figure 1.2. Such combinations typically move the components closer to the engine, where the temperature is higher. Typical temperatures and $\mathrm{NO}_{\mathrm{x}}$ concentration coming out from a light-duty diesel engine during a typical test cycle (World Harmonized Test Cycle) is shown in Figure 1.3. Here it is seen that typical operating conditions are between 180 and 400 ${ }^{\circ} \mathrm{C}$ and that $\mathrm{NO}_{\mathrm{x}}$ concentration may be as high as $2000 \mathrm{ppm}$ each with rapid fluctuations. Secondly, during active regenerations of the particulate filter large temperature excursions in the system are experienced. An example of a typical temperature profile during active regeneration of a DPF with SCR functionality is shown in Figure 1.4, where excursion above $650{ }^{\circ} \mathrm{C}$ are seen. This justifies the need for high activity at these temperatures and hydrothermal stability of the SCR component, which can only be obtained using transition metal exchanged zeolites, and in particular copper exchanged zeolites, which is the subject of this thesis.

Zeolites are crystalline aluminosilicates, composed of corner sharing $\left[\mathrm{SiO}_{4}\right]^{4-}$ and $\left[\mathrm{AlO}_{4}\right]^{5-}$ tetrahedra. They are a unique class of aluminosilicates because their crystalline structures consists of a network of well-defined micropores with 
diameters in the same range as small molecules (typically $0.3-2.0 \mathrm{~nm}$ ). Hence, larger molecules can not enter the micropore system i.e. the zeolites work as molecular sieves. Another feature, well exploited in catalysis, is that isomorphous substitution of silicon with aluminum atoms in the framework induces a negative charge on oxygen atoms around the aluminum, which must be compensated by a cation. In many catalytic applications the charge balancing ion is a proton which gives rise to Brønsted acidity as illustrated in Figure 1.5.

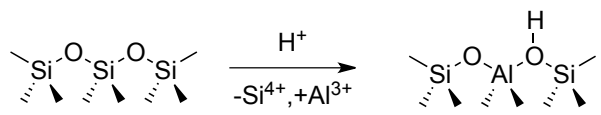

Figure 1.5: Illustration of the isomorphous substitution of $\mathrm{Si}$ with $\mathrm{Al}$ in zeolites and the creation of a Brønsted acidic site

The confinement and exclusion of molecules in combination with acidity has lead to widespread applications of zeolites within petrochemical refining applications. [7, 8] The ion exchange capacity also allows for introduction of catalytically active metal ions. From a heterogenous catalysis perspective a very unique set of opportunities are obtained due to the nature of the metal ions inside this type of material. This is because the highest possible degree of metal dispersion is obtained inside zeolites as it become atomically distributed throughout the crystals as extra-lattice ions. Furthermore, because the geometry and microenvironment for metal coordination is dictated by the well-ordered framework a similar fine tuning of the active metal site can be obtained that resemble the one nature perform in the active pockets of enzymes. For this reason metal exchanged zeolites catalyze a number of unique reactions. Some of the most typical and applied zeolite structures for catalytic applications are shown in Figure 1.6.

Of particular interest to this project is the ability of metal exchanged zeolites to catalyze the SCR reaction, and especially copper-exchanged zeolites, because they show higher catalytic activity in combination with good hydrothermal stability than other traditional candidates such as $\mathrm{V}_{2} \mathrm{O}_{5} / \mathrm{TiO}_{2}$-type catalysts.

In Figure 1.7 is shown current state-of-the-art understanding of $\mathrm{NH}_{3}-\mathrm{SCR}$ pathways and a proposed mechanism for the low-temperature catalytic cycle over isolated copper ions adapted from the work of Brandenberger et al.[10] and Gao 

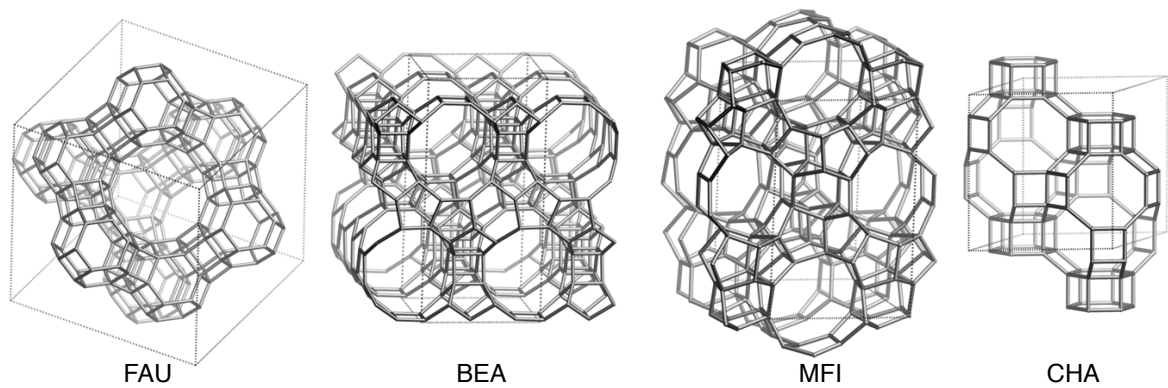

Figure 1.6: Graphical representation of the crystal structure of FAU, BEA (polymorph A), MFI and CHA. Each solid bar represent an oxygen bridge between corner sharing tetrahedrally coordinated Si or Al atoms. Structures were adapted from[9]

et al.[11] respectively. Many proposals on the reaction mechanism have postulated that the oxidation of $\mathrm{NO}$ to $\mathrm{NO}_{2}$ is the rate limiting step for the $\mathrm{NH}_{3}-\mathrm{SCR}$ reaction $[10,12,13]$. However, the oxidation of $\mathrm{NO}$ does not proceed as fast as the SCR reaction (or fast SCR reaction) over metal exchanged zeolites; especially at low temperatures and the inconsistency has been argued to rely on the $\mathrm{NO}_{2}$ desorption being limiting and that the SCR reaction then drives the desorption forward. To argue against this mechanism Ruggeri et al. recently performed a set of steady state transient kinetic experiments that disfavor the $\mathrm{NO}$ to $\mathrm{NO}_{2}$ oxidation being rate limiting and they argued that decomposition of nitrates and reoxidation of the metal center are rate determining steps.[14] Further evidence for the copper undergoing a redox cycle has also recently been shown convincingly by Kaspersky et al. who investigated the reaction using operando XAFS to show the presence of $\mathrm{Cu}^{+}$under differential SCR conditions indicating that this is indeed part of the mechanism and could be related to the rate determining step.[15] Thus, a complete understanding of the reaction mechanism has not yet been obtained, and there seem to be room for further investigation. 


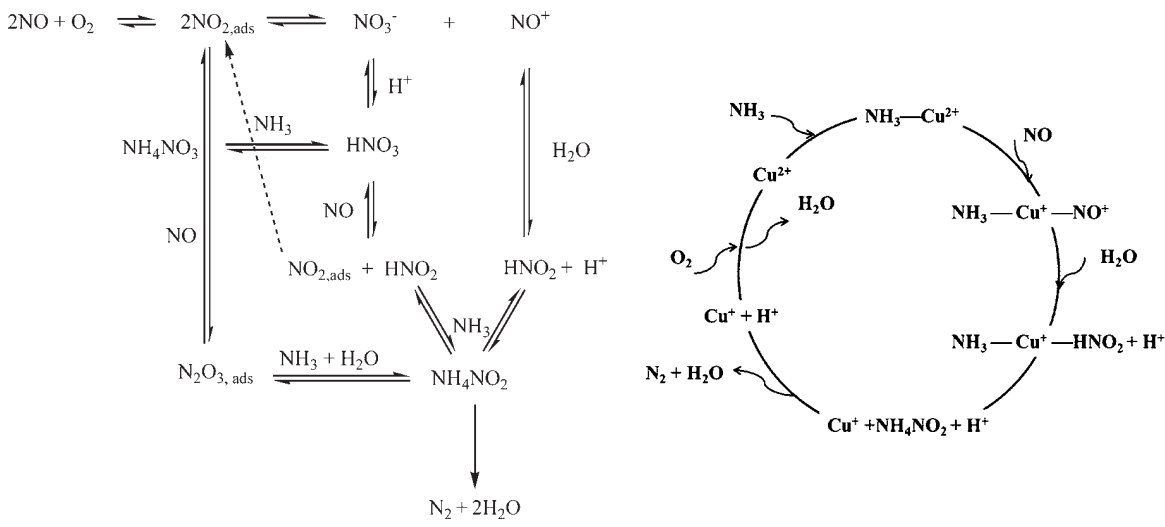

Figure 1.7: Current state-of-the-art proposals for $\mathrm{NH}_{3}$-SCR mechanisms over metal exchanged zeolites. To the left SCR reaction pathways summarized by Brandenberger et al.[10]. To the right low-temperature standard $\mathrm{NH}_{3}-\mathrm{SCR}$ reaction pathways catalyzed by isolated $\mathrm{Cu}$-ion monomers proposed by Gao et al.[11]

\subsection{Objectives and outline of the thesis}

The primary goal of this thesis is to explore and understand key issues involved in the use of metal exchanged zeolites as active catalysts in the removal of $\mathrm{NO}_{\mathrm{x}}$ through selective catalytic reduction with ammonia as reductant. Specifically, the influence of framework structure on activity and selectivity is considered and exploited for better understanding of hydrothermal deactivation of $\mathrm{Cu}$-zeolites. This has been achieved by performing synthesis, characterization and testing of a series of various $\mathrm{Cu}$-zeolites. Chapter 2 deals with an initial study of the catalytic performance of several commercially available zeolites, as well as a few home-made frameworks previously reported active in the $\mathrm{NH}_{3}-\mathrm{SCR}$ reaction. By comparing the catalytic performance of $\mathrm{Cu}$-zeolites with similar copper loadings the specific structure-performance and -stability as well as structure-selectivity relationships are established. In Chapter 3 resistance towards hydrocarbon poisoning on the three most promising framework topologies found in Chapter 2 is further explored. Special emphasis is put on the comparison of small pore zeolite $\mathrm{Cu}-\mathrm{SSZ}-13$ and silicoaluminophosphate $\mathrm{Cu}-\mathrm{SAPO}-34$ with similar $\mathrm{CHA}$ framework topologies, but different chemical framework compositions. The fol- 
lowing two chapters elaborates on the differences between Cu-SAPO-34 and $\mathrm{Cu}-\mathrm{SSZ}-13$. In the case of SAPO-34 an inhomogenous distribution of copper after aqueous ion exchange is found, which gives initial inferior performance. However, Cu-species can be redistributed thermally leading to superior activity as demonstrated in Chapter 4. Further understanding of the migration mechanism is achieved and the influence of the chemical composition of the atmosphere on activation is investigated in Chapter 5. Although small porezeolites has shown improved hydrothermal stability, the underlying mechanism of deactivation has remained unclear. To better understand the various contributions to hydrothermal deactivation of $\mathrm{Cu}$-zeolites Chapter 6 investigates the hydrothermal deactivation mechanism of copper zeolites. This is explored by the use of $\mathrm{Cu}-\mathrm{ZSM}-5$ and $\mathrm{Cu}-\mathrm{IM}-5$, which have very similar structural features, but slightly different framework dealumination behavior. Finally, Chapter 7 summarizes the results obtained in the thesis, puts them in perspective for the use in automotive applications and identifies some of the future challenges in the understanding of $\mathrm{Cu}$-zeolites for environmental applications.

Each chapter in the thesis is written so that it can be read independently. Consequently some overlap is inevitable. 
CHAPTER 2

\section{Screening of various zeolite framework topologies for}

$\mathrm{NH}_{3}-\mathrm{SCR}$

\subsection{Introduction}

Today there are more than 200 known zeolite topologies[9] and many of them have a wide range of compositions. All of these frameworks are potential candidates as catalysts for the $\mathrm{NH}_{3}$-SCR reaction. In practice, the industry is limited to a small number of topologies as a consequence of the ease-of-preparation, template cost and relevant composition. For the abatement of $\mathrm{NO}_{\mathrm{x}}$ using copper zeolites, by far most literature data is available for $\mathrm{Cu}-\mathrm{MFI}, \mathrm{Cu}-\mathrm{BEA}, \mathrm{Cu}-\mathrm{FAU}$, $\mathrm{Cu}-\mathrm{MOR}$ and $\mathrm{Cu}-\mathrm{FER} .[16-27]$

Over the years less common topologies, which are not commercially available, have also been studied as potential candidates for the SCR reaction, [28-35]. Most recently $\mathrm{Cu}-\mathrm{CHA}$ has attracted much attention due to its high hydrothermal stability, compared to other topologies,[36] which has also lead to its recent commercial production.

In an effort to better understand the benefits and differences between zeolite topologies in the $\mathrm{NH}_{3}$-SCR reaction, eight different topologies were selected for 
study in this chapter, including: MFI, BEA, FAU, MOR, FER, as well as CHA, SZR and LEV. The last two frameworks were specifically synthesized for this study in order to introduce into the study a more comprehensive list of pore sizes and dimensionalities. An overview of the topological features of these zeolites is provided in Table 2.1. To avoid the discrepancies from influence of different chemical compositions, zeolites with similar $\mathrm{Si} / \mathrm{Al}$ ratios and alike copper contents were used. These Cu-zeolites were evaluated in the $\mathrm{NH}_{3}$-SCR reaction and the $\mathrm{NO}_{\mathrm{x}}$ and $\mathrm{NH}_{3}$ conversion was compared as well as the selectivity towards unwanted $\mathrm{N}_{2} \mathrm{O}$.

Table 2.1: Overview of the frameworks together with structural features. The window size is defined by the number of T-atoms (given in bold), and size of the larges sphere that can diffuse through (given in parenthesis). The dimensionality is indicated by and asterix $\left(*=1 \mathrm{D}, * *=2 \mathrm{D}\right.$ and $\left.3^{* * *}=3 \mathrm{D}\right)$ and the $\leftrightarrow$ indicates intersecting channels. Data were adapted from [9]

\begin{tabular}{lll}
\hline FTC & window size and dimensionality & rings in the structure \\
\hline BEA & $\mathbf{1 2}^{* * *}(5.95 \AA)$ & $12-6-5-4$ \\
FAU & $\mathbf{1 2}^{* * *}(7.35 \AA)$ & $12-6-4$ \\
MOR & $\mathbf{1 2}^{*} \leftrightarrow \mathbf{8}^{* * *}(6.45 \AA$ and $2.95 \AA)$ & $10-8-5-4$ \\
MFI & $\mathbf{1 0}^{* * *}(4.46-4.70 \AA)$ & $10-6-5-4$ \\
SZR & $\mathbf{1 0}^{*} \leftrightarrow \mathbf{8}^{* *}(4.69 \AA$ and $3.32 \AA)$ & $10-8-6-5-4$ \\
CHA & $\mathbf{8}^{* * *}(3.72 \AA)$ & $8-6-4$ \\
FER & $\mathbf{1 0}^{*} \leftrightarrow \mathbf{8}^{*}(4.69 \AA$ and $3.40 \AA)$ & $10-8-6-5$ \\
LEV & $\mathbf{8}^{* *}(3.53 \AA)$ & $8-6-4$ \\
\hline
\end{tabular}

\subsection{Experimental}

Zeolite SUZ-4 (SZR topology) was synthesized according to an earlier reported procedure.[30, 37] The preparation involved first dissolving $24.65 \mathrm{~g} \mathrm{KOH}(96 \%$, Riedel-de Haën) in $139.6 \mathrm{~g}$ demineralized water followed by addition of metallic aluminum (99.7\%, Aldrich), whereupon hydrogen was released (duration ca. 1 day). In a second beaker $74.73 \mathrm{~g} 35$ wt.\% tetraethyl ammonium hydroxide (35 wt. $\%$ in $\mathrm{H}_{2} \mathrm{O}$, Aldrich) was diluted with $118.9 \mathrm{~g}$ demineralized water. And the former $\mathrm{KOH}+\mathrm{Al}$ solution as well as $143.7 \mathrm{~g}$ Ludox AS40 (40 wt.\%, Aldrich) was added simultaneously under magnetic stirring. After one hour stirring the gel was transferred to a teflon lined autoclave and heated to $150{ }^{\circ} \mathrm{C}$ under rotation 
for 4 days. Finally, the product was recovered by vacuum filtration, washed with at least $3.0 \mathrm{~L}$ of deminerilized water, dried at $100{ }^{\circ} \mathrm{C}$ and calcined at 580 ${ }^{\circ} \mathrm{C}$ for $3 \mathrm{~h}$ to remove the organic template.

Zeolite Nu-3 (LEV topology) was prepared according to a similar procedure as reported in [33, 38-41]. In this particular case two solutions were made; one containing 26.29 g Ludox AS40 (40 wt.\%, Aldirch), $55.42 \mathrm{~g}$ deminiralized $\mathrm{H}_{2} \mathrm{O}$ and $8.83 \mathrm{~g}$ 1-adamantylamine (97\%, Aldirch) and another containing $3.58 \mathrm{~g}$ $\mathrm{Al}(\text { iso-PrO })_{3}$ ( $\geq 98 \%$, Aldrich), $0.75 \mathrm{~g} \mathrm{NaOH}(>98 \%$, Scharlau) and $55.42 \mathrm{~g}$ deminiralized $\mathrm{H}_{2} \mathrm{O}$. Both solutions were stirred for $1 \mathrm{~h}$ and finally the latter solution was added drop wise to the former and the gel transferred to teflon lined autoclaves. These were heated to $175{ }^{\circ} \mathrm{C}$ for 9 days under rotation and the product recovered by suction filtration and washed with plenty of demineralized water. Finally, the product was dried at $100{ }^{\circ} \mathrm{C}$ and calcined at $580{ }^{\circ} \mathrm{C}$ for $3 \mathrm{~h}$ to remove the organic template.

To obtain the $\mathrm{NH}_{4}$-form of the LEV and SZR zeolites they were ion exchanged with $\mathrm{NH}_{4} \mathrm{Cl}$. This was carried out two consecutive times at $80{ }^{\circ} \mathrm{C}$ for $2 \mathrm{~h}$ to ensure a sufficient exchange with a solid to liquid ratio of $10 \mathrm{w} / \mathrm{w}$ in a $2.5 \mathrm{M}$ $\mathrm{NH}_{4} \mathrm{Cl}$ solution (made from $\geq 99.5 \%$, Sigma).

The other zeolites: Beta (BEA), USY (FAU), Mordenite (MOR), ZSM-5 (MFI), SSZ-13 (CHA) and Ferierite (FER) zeolites were obtained from commercial suppliers. All zeolites were dried at $100{ }^{\circ} \mathrm{C}$ prior to the introduction of $\mathrm{Cu}$ by an excessive impregnation procedure that can be described as: first the zeolite powder was suspended in a solution containing copper nitrate in an amount corresponding to 2.8 wt. $\% \mathrm{Cu}$ in the final product, then the solution was stirred for one hour and the excess liquid evaporated at $100{ }^{\circ} \mathrm{C}$. All zeolites were then calcined at $500{ }^{\circ} \mathrm{C}$ for 3 hours prior to any catalytic testing.

The $\mathrm{Si}, \mathrm{Al}$, and $\mathrm{Cu}$ contents were measured by ICP-OES with a Varian 715-ES instrument after acid-digestion.

$\mathrm{NO}_{\mathrm{x}}$ and $\mathrm{NH}_{3}$ conversions as well as the selectivity towards $\mathrm{N}_{2} \mathrm{O}$ in the $\mathrm{NH}_{3}-$ $\mathrm{SCR}$ reaction was measured in a fixed bed quartz reactor (i.d. $2 \mathrm{~mm}$ ) using 20 mg catalyst sample (150-300 $\mu \mathrm{m}$ sieve fraction). Catalysts were pre-treated $1 \mathrm{~h}$ in $10 \% \mathrm{O}_{2}$ at $550{ }^{\circ} \mathrm{C}$ prior to any measurements. Afterwards the catalysts were stepwise cooled down to $170{ }^{\circ} \mathrm{C}$ in a reaction gas containing $500 \mathrm{ppm}$ NO, 530 ppm $\mathrm{NH}_{3}, 10 \% \mathrm{O}_{2}$, and $5 \% \mathrm{H}_{2} \mathrm{O}$, and steady state conversion and selectivity 
were measured at each temperature step. The reactant gas composition was balanced to a total flow rate of $300 \mathrm{NmL} / \mathrm{min}$ and the outlet gas was analyzed by a Gasmet CX4000 FTIR analyzer.

Aging of the $\mathrm{Cu}$-zeolites were carried out in the reactor setup described above. Before catalytic testing the catalyst was heated $\left(10{ }^{\circ} \mathrm{C} / \mathrm{min}\right)$ to $750{ }^{\circ} \mathrm{C}$ for 3 $\mathrm{h}$ in an atmosphere containing $10 \% \mathrm{H}_{2} \mathrm{O}$ and $10 \% \mathrm{O}_{2}$ and a flow rate of 100 $\mathrm{NmL} / \mathrm{min}$. Afterwards the catalysts were cooled down to reaction temperature and the testing performed in a similar manner as described above.

\subsection{Results and Discussion}

The zeolite topologies used in this study ranges from large-pore zeolites with 12MR windows down to small-pore zeolites, containing 8-MR windows, with only two-dimensional channel systems. Furthermore different ring sizes are present in the various structures (see Table 2.1), which also leads to various sites for copper coordination.

Table 2.2: Overview of $\mathrm{Cu}$-zeolites used for the screening study and catalytic conversion $\left(X_{\mathrm{NO}_{\mathrm{x}}}\right)$ at $180{ }^{\circ} \mathrm{C}$ in the $\mathrm{NH}_{3}-\mathrm{SCR}$ reaction. In the table the framework type code, the common name for the zeolite as well as $\mathrm{Si} / \mathrm{Al}$ ratios and copper content are reported

\begin{tabular}{llcccc}
\hline Material & Common name & $\mathrm{Si} / \mathrm{Al}$ & $\mathrm{Cu} /(\mathrm{Si}+\mathrm{Al})$ & $\mathrm{Cu}$ wt. $\%$ & $X_{\mathrm{NO}_{\mathrm{x}}}$ at $180{ }^{\circ} \mathrm{C}$ \\
\hline $\mathrm{Cu}-\mathrm{BEA}$ & $\mathrm{Cu}-\mathrm{Beta}$ & 13.2 & 0.0303 & 2.78 & 0.459 \\
$\mathrm{Cu}-\mathrm{FAU}$ & $\mathrm{Cu}-\mathrm{USY}$ & 16.5 & 0.0299 & 2.76 & 0.110 \\
$\mathrm{Cu}-\mathrm{MOR}$ & $\mathrm{Cu}-$ Mordenite & 10.0 & 0.0304 & 2.77 & 0.170 \\
$\mathrm{Cu}-\mathrm{MFI}$ & $\mathrm{Cu}-\mathrm{ZSM}-5$ & 12.4 & 0.0317 & 2.91 & 0.443 \\
$\mathrm{Cu}-\mathrm{SZR}$ & $\mathrm{Cu}-\mathrm{SUZ}-4$ & 8.1 & 0.0317 & 2.85 & 0.147 \\
$\mathrm{Cu}-\mathrm{CHA}$ & $\mathrm{Cu}-\mathrm{SSZ}-13$ & 15.5 & 0.0302 & 2.74 & 0.433 \\
$\mathrm{Cu}-\mathrm{FER}$ & $\mathrm{Cu}-\mathrm{Ferrierite}$ & 10.4 & 0.0299 & 2.80 & 0.039 \\
$\mathrm{Cu}-\mathrm{LEV}$ & $\mathrm{Cu}-\mathrm{Nu}-3$ & 9.3 & 0.0339 & 3.09 & 0.052 \\
\hline
\end{tabular}

Based on findings of Kwak et al., who found optimal copper loads in CHA zeolite SSZ-13 to be around $2.4-3.4$ wt.\% for the $\mathrm{NH}_{3}$-SCR reaction, [42] all catalyst were impregnated with the aim of obtaining $2.8 \mathrm{wt} . \% \mathrm{Cu}$ in the final materials. Copper contents and elemental composition of the prepared catalysts are given 
in Table 2.2. The copper content was not raised any higher because other studies have shown only little improvement to the conversion at low temperatures (170 $-250{ }^{\circ} \mathrm{C}$ ) after raising the copper content above $\mathrm{Cu} / \mathrm{Al}$ ratios of $0.5 \mathrm{in} \mathrm{MFI}$ and IMF zeolites (see Chapter 6). It should furthermore be added that comparison of activity between $\mathrm{Cu}$-zeolites should be carried out at low temperatures only, in order to disregard large effects from diffusion limitations.[43]

\subsubsection{Influence of zeolite framework topology on catalytic performance}

The conversion of $\mathrm{NO}_{\mathrm{x}}$ and $\mathrm{NH}_{3}\left(\mathrm{NO}+\mathrm{NO}_{2}\right)$ during the $\mathrm{NH}_{3}-\mathrm{SCR}$ reaction was studied over all the prepared $\mathrm{Cu}$-zeolites as a function of temperature (see Figure 2.1a). Between 170 and $300{ }^{\circ} \mathrm{C} \mathrm{NO}_{\mathrm{x}}$ and $\mathrm{NH}_{3}$ consumption follow the stoichiometry of the overall SCR reaction over all catalysts:

$4 \mathrm{NO}+4 \mathrm{NH}_{3}+\mathrm{O}_{2} \longrightarrow 4 \mathrm{~N}_{2}+6 \mathrm{H}_{2} \mathrm{O} \quad$ (standard $\mathrm{SCR}$ reaction)

In terms of conversion, the following order is observed at low temperatures:

$\mathrm{Cu}-\mathrm{FER}<\mathrm{Cu}-\mathrm{LEV} \ll \mathrm{Cu}-\mathrm{FAU}<\mathrm{Cu}-\mathrm{SZR}<\mathrm{Cu}-\mathrm{MOR} \ll \mathrm{Cu}-\mathrm{CHA} \approx \mathrm{Cu}-\mathrm{MFI} \approx \mathrm{Cu}-\mathrm{BEA}$

When comparing the $\mathrm{NO}_{\mathrm{x}}$ conversion only at $170-180{ }^{\circ} \mathrm{C}$ the performance may be divided into three groups: i) $\mathrm{Cu}-\mathrm{FER}$ and $\mathrm{Cu}-\mathrm{LEV}$ that show poor performance, ii) $\mathrm{Cu}-\mathrm{SZR}$ and $\mathrm{Cu}-\mathrm{MOR}$ that show intermediate performance and iii) $\mathrm{Cu}-\mathrm{BEA}, \mathrm{Cu}-\mathrm{MFI}$ and $\mathrm{Cu}-\mathrm{CHA}$ showing superior performance. The $\mathrm{NO}_{\mathrm{x}}$ conversion profile of $\mathrm{Cu}-\mathrm{FAU}$ is considerably different than the others and is therefore left out in this comparison. There does not seem to be a common denominator in terms of specific rings present in the structure (see Table 2.1). However, within each group specific framework features in terms of dimensionality seem to be present. In the poorest performing group (Cu-LEV and $\mathrm{Cu}-\mathrm{FER}$ ) the micropore system is two-dimensional. 

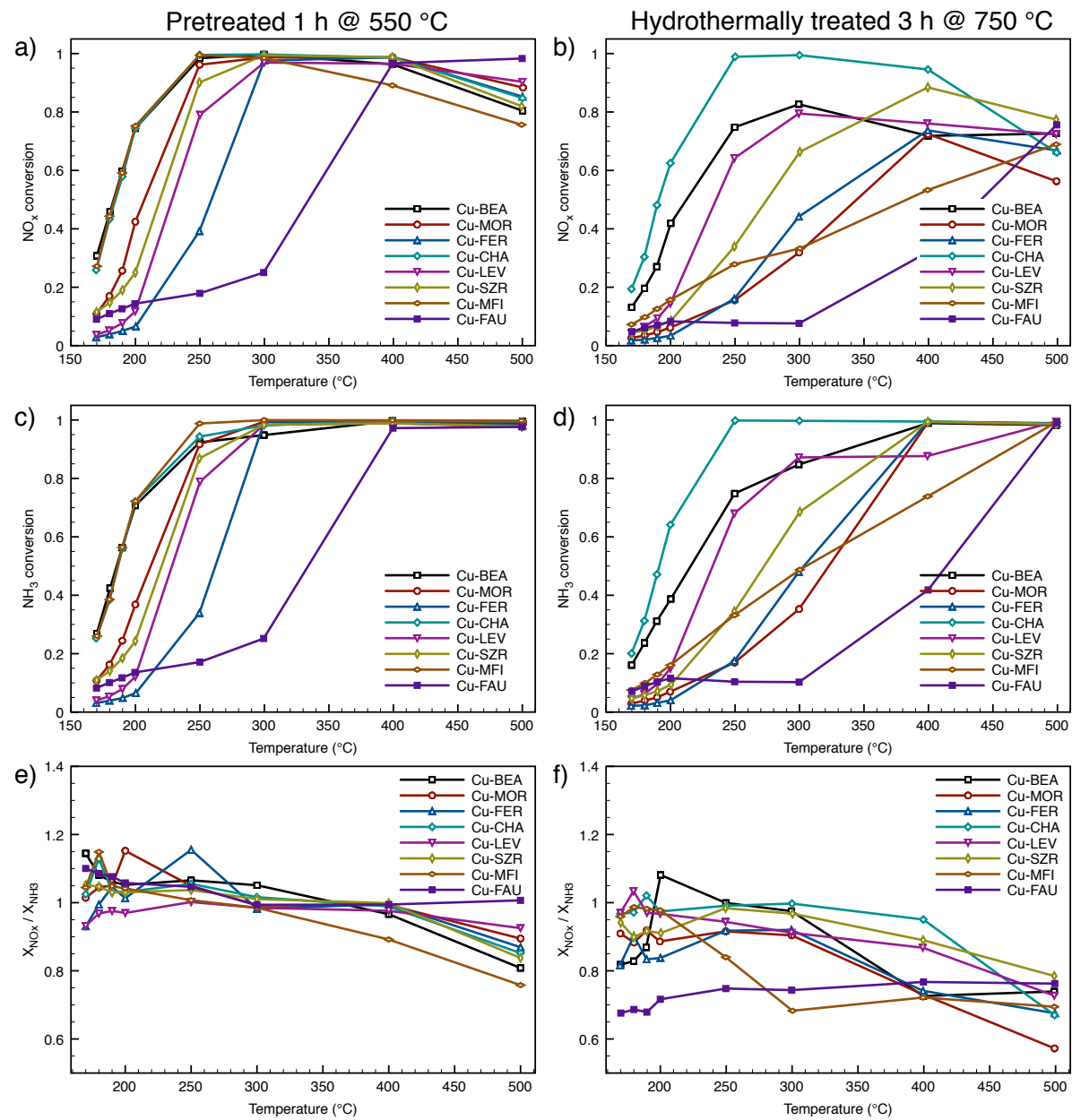

Figure 2.1: $\mathrm{NO}_{\mathrm{x}}$ conversion $(\mathrm{a}, \mathrm{b}), \mathrm{NH}_{3}(\mathrm{c}, \mathrm{d})$ conversion and the ratio of $\mathrm{NO}_{\mathrm{x}}$ and $\mathrm{NH}_{3}$ conversions $(\mathrm{e}, \mathrm{f})$ over various $\mathrm{Cu}$-zeolites in the $\mathrm{NH}_{3}-\mathrm{SCR}$ reaction. The left panel show the performance of the various $\mathrm{Cu}$-zeolites before hydrothermal aging and the right panel after $3 \mathrm{~h}$ in $10 \% \mathrm{H}_{2} \mathrm{O}$ and 10 $\% \mathrm{O}_{2}$ at $750{ }^{\circ} \mathrm{C}$. Conditions were $500 \mathrm{ppm} \mathrm{NO}, 530 \mathrm{ppm} \mathrm{NH}_{3}, 10 \% \mathrm{O}_{2}, 5$ $\% \mathrm{H}_{2} \mathrm{O}$, balance $\mathrm{N}_{2}$ to a total flow of $300 \mathrm{NmL} / \mathrm{min}$ and $20 \mathrm{mg}$ Cu-zeolite catalyst 
For the intermediate group the pore system can be described as having threedimensional pore systems, but with one direction having larger window sizes dictated by at least two additional T-atoms. This leads to a an average preferred diffusion direction in these zeolites, which may not be beneficial for the observable $\mathrm{NO}_{\mathrm{x}}$ conversion. Oppositely, the group of frameworks giving the highest observed $\mathrm{NO}_{\mathrm{x}}$ conversion all contain three-dimensional pore systems with similar window sizes in all three directions for each individual framework (all 8-member-rings, or all 10-member-rings etc.) The superior performance of group iii) does not seem to be dictated by specific window size as e.g. $\mathrm{Cu}-\mathrm{CHA}$ with only 8 -member-ring windows perform similar to $\mathrm{Cu}$-BEA that contain only 12 -member-ring windows. Instead the empirical criteria for good catalyst performance, derived from these data in this temperature interval, is the presence of three-dimensional pore systems with similar window sizes in all directions.

In the intermediate temperature range between 250 and $300{ }^{\circ} \mathrm{C}$ the conversion increases over all catalysts in a similar manner, except for $\mathrm{Cu}-\mathrm{FAU}$ where the increase is less and as a consequence it shows the lowest performance in the intermediate temperature range and up to $400{ }^{\circ} \mathrm{C}$. The inferior performance of $\mathrm{Cu}-\mathrm{FAU}$ could be a consequence of dealumination as all samples were treated one hour under reaction conditions containing $5 \% \mathrm{H}_{2} \mathrm{O}$ at $550{ }^{\circ} \mathrm{C}$ prior to activity measurements. This is typical conditions for zeolite $\mathrm{Y}$ dealumination and thus one explanation for its poor performance is the loss of active sites due to dealumination. Further explanations for this behavior was not pursued in this study.

At higher temperatures $\left(>300{ }^{\circ} \mathrm{C}\right)$ the measured $\mathrm{NO}_{\mathrm{x}}$ conversion decreases slightly for all catalysts except $\mathrm{Cu}-\mathrm{FAU}$. Since all of the $\mathrm{NH}_{3}$ is converted, see Figure 2.1c, the decrease in observed $\mathrm{NO}_{\mathrm{x}}$ conversion can be ascribed to the competition between $\mathrm{SCR}$ reaction and unselective $\mathrm{NH}_{3}$ oxidation:

$4 \mathrm{NH}_{3}+5 \mathrm{O}_{2} \longrightarrow 4 \mathrm{NO}+6 \mathrm{H}_{2} \mathrm{O}$

$2 \mathrm{NH}_{3}+2 \mathrm{O}_{2} \longrightarrow 4 \mathrm{~N}_{2} \mathrm{O}+3 \mathrm{H}_{2} \mathrm{O}$

$4 \mathrm{NH}_{3}+3 \mathrm{O}_{2} \longrightarrow 2 \mathrm{~N}_{2}+6 \mathrm{H}_{2} \mathrm{O}$

This is more easily visualized by the ratio between observed $\mathrm{NO}_{\mathrm{x}}$ and $\mathrm{NH}_{3}$ conversion as shown in Figure 2.1e where a decreasing number is seen for all catalysts at higher temperature. 


\subsubsection{Influence of zeolite framework topology on hydrother- mal stability}

The measured $\mathrm{NO}_{\mathrm{x}}$ and $\mathrm{NH}_{3}$ conversion as well as the ratio between the two after hydrothermal aging are shown in Figure 2.1b,d and e respectively. For all catalysts, except the $\mathrm{Cu}-\mathrm{LEV}$, the performance in terms of $\mathrm{NO}_{\mathrm{x}}$ conversion has decreased at all temperatures. This behavior has occurred to a different extent for the various frameworks. To better compare the difference it can be assumed that the activity follow a first order dependence in terms of NO.[18, 21, 43] In this way, neglecting the differences in pressure drop over the reactor, the relative activity at a specific temperature for each $\mathrm{Cu}$-zeolite before and after hydrothermal aging can be compared, where $X_{\mathrm{NO}_{\mathrm{x}}}$ is the conversion of $\mathrm{NO}_{\mathrm{x}}$ :

$$
\text { relative activity change }=\frac{\ln \left(1-X_{\mathrm{NO}_{\mathrm{x}, \text { after }}}\right)}{\ln \left(1-X_{\mathrm{NO}_{\mathrm{x}, \text { before }}}\right)}
$$

The relative activity after aging was calculated for all $\mathrm{Cu}$-zeolites, except for $\mathrm{Cu}-\mathrm{FAU}$, which was already deactivated before the initial test (see discussion above), and is shown in Figure 2.2 for $180{ }^{\circ} \mathrm{C}$. Interestingly, the activity of $\mathrm{Cu}-\mathrm{LEV}$ have improved slightly in the temperatures tested below $250{ }^{\circ} \mathrm{C}$ after the hydrothermal aging. It should also be noted that at higher temperatures the $\mathrm{Cu}-\mathrm{LEV}$ deactivates in a similar manner as the other catalysts. One explanation for the peculiar increase in low-temperature activity is the ability of copper to migrate into ion exchange positions after an incomplete exchange during impregnation. This subject will not be covered in this chapter, see instead Chapter 4, 5 and 6. Instead the discussion will be limited to the overall trend that the most stable $\mathrm{Cu}$-zeolite appear to be dominated by frameworks with small window sizes. During hydrothermal treatment dealumination most likely play a significant role in catalyst deactivation. This is because when aluminum leaves the framework the ion exchange site for copper, which is the active site, is lost. Fickel et al. explain the limited dealumination in small-pore zeolites by considering the kinetic diameter of $5.0 \AA$ for an $\mathrm{Al}(\mathrm{OH})_{3}$ moiety. The diameter of this moiety is larger than what can be expected in zeolites with 8-memberring windows. For this reason the aluminum hydroxide moiety cannot exit the pores of the framework and thus the integrity of the framework can be preserved by reinsertion of the aluminum into the framework upon subsequent cooling.[33] This explain well why $\mathrm{Cu}-\mathrm{LEV}, \mathrm{Cu}-\mathrm{CHA}$ and to some extent $\mathrm{Cu}-\mathrm{FER}$ and $\mathrm{Cu}-$ SZR preserve more activity than e.g. Cu-MFI. The Cu-BEA is however very similar to the $\mathrm{Cu}-\mathrm{SZR}$ and considerable activity is preserved in this material. Instead the explanation must be found in the fact that BEA zeolites contain 
a large amount of structural defects compared to other zeolite systems.[44, 45] Although these defects does not improve the integrity of the framework they serve as new locations for $\mathrm{Al}$ insertion and in this way the exchange site can overall be preserved.

In terms of absolute numbers $\mathrm{Cu}$-CHA outperforms all other candidates. This is best observed in Figure 2.1b and d, where $\mathrm{Cu}$-CHA shows the highest $\mathrm{NO}_{\mathrm{x}}$ and $\mathrm{NH}_{3}$ of all candidates at temperatures between 170 and $400{ }^{\circ} \mathrm{C}$. This is the temperature interval most important for automotive applications as described in Chapter 1 and for this reason this type of material has attracted enormous interest in recent years.[33, 36, 42, 43, 46-51]

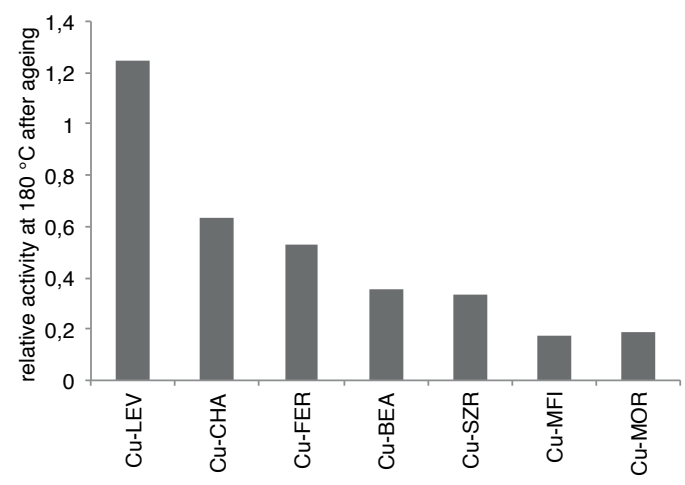

Figure 2.2: Relative activity calculated according to Equation 2.1 for the various $\mathrm{Cu}$-zeolites at $180{ }^{\circ} \mathrm{C}$. Conditions for the catalytic test were: $500 \mathrm{ppm}$

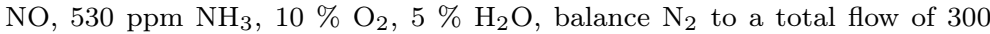
$\mathrm{NmL} / \mathrm{min}$ and $20 \mathrm{mg} \mathrm{Cu}$-zeolite catalyst and hydrothermal aging was carried out at $750{ }^{\circ} \mathrm{C}$ for $3 \mathrm{~h}$ in $10 \% \mathrm{O}_{2}$ and $10 \% \mathrm{H}_{2} \mathrm{O}$ at $100 \mathrm{NmL} / \mathrm{min}$

\subsubsection{Formation of $\mathrm{N}_{2} \mathrm{O}$ depending on zeolite framework topology}

With increasing SCR activity, metal exchanged zeolites tend to also form nitrous oxide, $\mathrm{N}_{2} \mathrm{O}$, which is undesirable due to its reactivity towards ozone and play a role as potent greenhouse gas and air as a pollutant in general. The formation of $\mathrm{N}_{2} \mathrm{O}$ over $\mathrm{Cu}$-zeolites occurs primarily through these five reactions:[10] 
$2 \mathrm{NH}_{3}+2 \mathrm{NO}_{2} \longrightarrow \mathrm{N}_{2} \mathrm{O}+\mathrm{N}_{2}+3 \mathrm{H}_{2} \mathrm{O}$

$6 \mathrm{NH}_{3}+8 \mathrm{NO}_{2} \longrightarrow 7 \mathrm{~N}_{2} \mathrm{O}+9 \mathrm{H}_{2} \mathrm{O}$

$2 \mathrm{NH}_{3}+2 \mathrm{O}_{2} \longrightarrow \mathrm{N}_{2} \mathrm{O}+3 \mathrm{H}_{2} \mathrm{O}$

$4 \mathrm{NH}_{3}+4 \mathrm{NO}_{2}+\mathrm{O}_{2} \longrightarrow 4 \mathrm{~N}_{2} \mathrm{O}+6 \mathrm{H}_{2} \mathrm{O}$

$4 \mathrm{NH}_{3}+4 \mathrm{NO}+3 \mathrm{O}_{2} \longrightarrow 4 \mathrm{~N}_{2} \mathrm{O}+6 \mathrm{H}_{2} \mathrm{O}$

Experimentally, the production of $\mathrm{N}_{2} \mathrm{O}$ is seen to increase up to about $250{ }^{\circ} \mathrm{C}$ whereafter the concentration in the effluent gas decreases due to decomposition that is further assisted by the presence of NO.[52-54]. From the reactions above it is clear that $\mathrm{NH}_{3}$ play a significant role in the formation of $\mathrm{N}_{2} \mathrm{O}$. Therefore the selectivity is defined from the sum of $\mathrm{NH}_{3}$ and $\mathrm{NO}_{\mathrm{x}}$ in the feed:

$$
\mathrm{N}_{2} \mathrm{O} \text { selectivity }=\frac{2 \cdot c_{\mathrm{N}_{2} \mathrm{O}, \text { out }}}{\left(c_{\mathrm{NH}_{3}}+c_{\mathrm{NO}_{\mathrm{x}}}\right)_{\text {in }}-\left(c_{\mathrm{NH}_{3}}+c_{\mathrm{NO}_{\mathrm{x}}}\right)_{\text {out }}}
$$

In contrast to the activity towards $\mathrm{NO}_{\mathrm{x}}$ in the $\mathrm{SCR}$ reaction, the selectivity of $\mathrm{N}_{2} \mathrm{O}$ at the maximum production at $250{ }^{\circ} \mathrm{C}$ follow the size and dimensionality of the pore system for $\mathrm{Cu}$-zeolites (see Figure 2.3):

$$
\mathrm{Cu}-\mathrm{LEV} \approx \mathrm{Cu}-\mathrm{FER}<\mathrm{Cu}-\mathrm{CHA} \leq \mathrm{Cu}-\mathrm{SZR} \leq \mathrm{Cu}-\mathrm{MFI}<\mathrm{Cu}-\mathrm{MOR}<\mathrm{Cu}-\mathrm{FAU} \leq \mathrm{Cu}-\mathrm{BEA}
$$

Larger windows and increased dimensionality of the zeolite pore system give higher selectivities towards $\mathrm{N}_{2} \mathrm{O}$. Thus, it would appear that the selectivity is little dependent on the activity of the catalyst at similar copper loads. The difference in selectivity can instead be explained by the average residence time of $\mathrm{N}_{2} \mathrm{O}$ in the pores of the zeolite with different framework topologies, which implies a diffusion limitation for $\mathrm{N}_{2} \mathrm{O}$.

Smeets et al. found that direct $\mathrm{N}_{2} \mathrm{O}$ decomposition is very dependent on copper and speciation as a function of the topology and follow the trend: $\mathrm{Cu}-\mathrm{MFI}>$ $\mathrm{Cu}-\mathrm{MOR}>\mathrm{Cu}-\mathrm{FER}>\mathrm{Cu}-\mathrm{MOR}>\mathrm{Cu}-\mathrm{BEA}$, which in their case corresponded to the average $\mathrm{Cu}-\mathrm{Cu}$ distance and the catalyst ability to facilitate oxygen migration enabling recombination into gaseous oxygen.[54] However when NO is present, it can scavenge the adsorbed oxygen and facilitate the $\mathrm{N}_{2} \mathrm{O}$ decomposition by:

$\mathrm{N}_{2} \mathrm{O}+* \longrightarrow \mathrm{N}_{2}+\mathrm{O} *$

$\mathrm{O} *+\mathrm{NO} \longrightarrow \mathrm{NO}_{2} *$ 
where at least in our case, the $\mathrm{NO}_{2}$ can undergo the fast $\mathrm{SCR}$ reaction. Moreover, when $\mathrm{NO}$ is present in the gas $\mathrm{N}_{2} \mathrm{O}$ decomposition become independent on topology and more dependent on copper load. A similar role could also be ascribed to $\mathrm{NH}_{3} \cdot[55]$

For the zeolites investigated in this study they all contain similar amounts of copper and therefore the inherent decomposition activity should be almost similar. Ultimately this means that the decomposition of $\mathrm{N}_{2} \mathrm{O}$ should correlate with the residence time of formed $\mathrm{N}_{2} \mathrm{O}$, if it is generated in a similar manner on all $\mathrm{Cu}$-zeolites. Moreover, the residence time is dependent on the diffusivity of $\mathrm{N}_{2} \mathrm{O}$ in the various framework, which will decrease for small pore zeolites and decreased dimensionality. This provides a reasonable explanation for the experimentally observed $\mathrm{N}_{2} \mathrm{O}$ selectivity over the various Cu-zeolites in the $\mathrm{NH}_{3}-\mathrm{SCR}$ reaction as seen in Figure 2.3. The production of $\mathrm{N}_{2} \mathrm{O}$ measured in the gas effluent follow the same order as a consequence of the high conversion. This is except for the $\mathrm{Cu}-\mathrm{FAU}$ zeolite, which again show a drastically different SCR behavior than the other zeolites used in this investigation.

As a consequence of the different hydrothermal deactivation of the Cu-zeolites, the $\mathrm{N}_{2} \mathrm{O}$ selectivity could not be compared directly. Moreover, several of the catalyst had deactivated to a great extent and thus the $\mathrm{N}_{2} \mathrm{O}$ production had decreased to below the measurable limit of the FTIR detector. For this reason the comparison between $\mathrm{N}_{2} \mathrm{O}$ selectivity is not made for the deactivated catalysts.

The observation that smaller pores and decreased dimensionality results in decreased selectivity towards $\mathrm{N}_{2} \mathrm{O}$, allows for improved design of future $\mathrm{Cu}$ zeolite SCR catalysts as in EURO-VII legislation where $\mathrm{N}_{2} \mathrm{O}$ will be strictly regulated.[5] Beside the correlation between window size and pore dimensionality as shown in this chapter, the total $\mathrm{N}_{2} \mathrm{O}$ production will also depend on the total $\mathrm{Cu}$-loading (see e.g. results in Chapter 6), which also dictate the overall activity. Thus an optimum between the two must be found. 


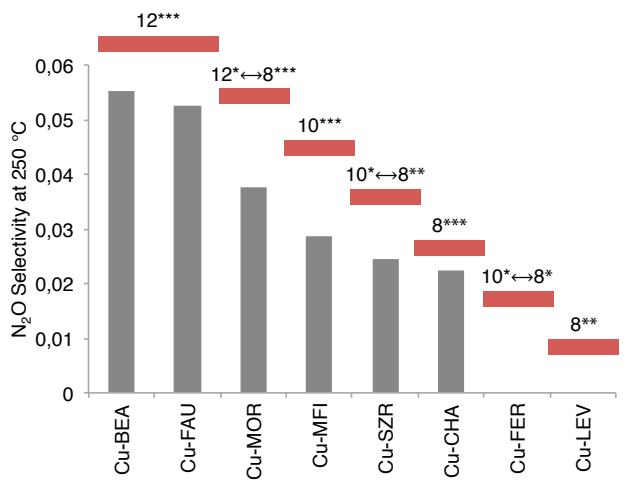

a)

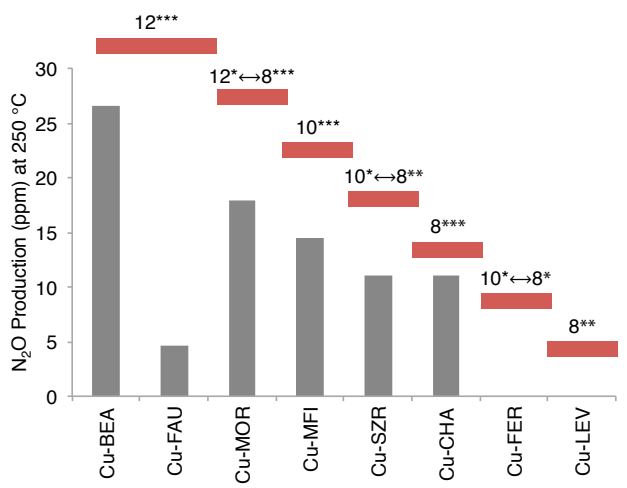

b)

Figure 2.3: $\mathrm{N}_{2} \mathrm{O}$ selectivity (top) and $\mathrm{N}_{2} \mathrm{O}$ production (bottom) over various copper zeolites (in the fresh state) at $250{ }^{\circ} \mathrm{C}$ for the $\mathrm{NH}_{3}$-SCR reaction. The ring size of windows in the structure is given as well as the dimensionality with the asterix number $(*=1 \mathrm{D}, * *=2 \mathrm{D}$ and $* * *=3 \mathrm{D})$ above the bar graphs. Conditions were the same as described in Figure 2.1

\subsection{Summary and Conclusions}

Various $\mathrm{Cu}$-zeolites were prepared with similar copper content and similar $\mathrm{Si} / \mathrm{Al}$ ratios for comparison in the $\mathrm{NH}_{3}$-SCR reaction. It was shown that the $\mathrm{SCR}$ activity in terms of $\mathrm{NO}_{\mathrm{x}}$ conversion over the $\mathrm{Cu}$-zeolites could be divided into three groups depending on the dimensionality of the pore system. The zeolites most favorable for the SCR reaction were found to be $\mathrm{Cu}-\mathrm{BEA}, \mathrm{Cu}-\mathrm{MFI}$ and $\mathrm{Cu}-\mathrm{CHA}$. After hydrothermal aging the $\mathrm{Cu}-\mathrm{CHA}$ showed the best overall per- 
formance, and deactivation was shown to be less severe over zeolites with small pores, except for the $\mathrm{Cu}$-BEA which did not follow this trend.

Interestingly, the $\mathrm{N}_{2} \mathrm{O}$ selectivity was shown to be dependent on both the pore size and the dimensionality of the pore system where large windows and 3dimensional pore systems favored $\mathrm{N}_{2} \mathrm{O}$ formation at $250{ }^{\circ} \mathrm{C}$. An explanation for this behavior was given as a an increased probability for $\mathrm{N}_{2} \mathrm{O}$ decomposition increases with the residence time that will increase with smaller pores and lower dimensionality.

\subsection{Future work}

The results shown in this chapter indicate that the $\mathrm{N}_{2} \mathrm{O}$ selectivity depend on the pore size and dimensionality of the copper loaded zeolite. This implies that diffusion limitations for $\mathrm{N}_{2} \mathrm{O}$ are present. In order to verify this hypothesis future work should include studies on the diffusivity of $\mathrm{N}_{2} \mathrm{O}$ for various zeolite framework topologies. 
CHAPTER 3

\section{Hydrocarbon resistance of Cu-zeolites in the $\mathrm{NH}_{3}-\mathrm{SCR}$}

reaction

\section{$3.1 \quad$ Introduction}

One issue related to the use of $\mathrm{Cu}$-zeolites for automotive applications is their resistance towards hydrocarbons $(\mathrm{HC})$. Concentrations of HCs from internal diesel combustion engines ranges from 20 to approximately $300 \mathrm{ppm}$ with up to 24 C-atoms in the volatile part.[56] Depending on the application and engine operation different types and amounts of hydrocarbons will be present in the exhaust stream. For example $0.01 \mathrm{~g}$ propylene emission is expected per mile for light-duty engines whereas negligible amounts is expected for heavy-duty engines. On the contrary about $0.01 \mathrm{~g} n$-decane emissions are expected per mile for heavy duty engines, but negligible amounts for light-duty engines.[56]

In modern emission control systems $\mathrm{HCs}$ are, or should be, removed by an up-stream diesel oxidation catalyst (DOC), see Figure 1.2, but failure or nonpresence of the DOC will expose the SCR catalyst to volatile hydrocarbons. Similarly, the SCR catalyst may experience increased HC levels if up-stream particulate filters are regenerated. The regeneration is typically carried out by direct injection of hydrocarbons (diesel fuel) to the DOC, where it is oxidized 
to create high-temperature excursions. Again, if the DOC does not convert all hydrocarbons or the oxygen content is insufficient, then the SCR catalysts will be exposed to HCs.

Most prior work on HCs and Cu-zeolites for SCR applications has been focused on the the use of HCs as a reductant in the SCR reaction (HC-SCR), see e.g. [57-59] The SCR reaction with HCs is slower compared to the one with $\mathrm{NH}_{3}$ and the light-off temperature is higher. For this reason the preferred choice for practical applications in the automotive industry is the use of $\mathrm{NH}_{3}$-SCR. Little work has however been carried out on the competition or poisoning effect of HCs when ammonia is also present in the gas. Yang et al. investigated catalyst poisoning on Fe-ZSM-5 and Fe-Beta and found that $\mathrm{Fe}^{3+}$ sites are blocked by propene or products derived from propene.[60, 61] They also found that Brønsted sites were not severely influenced. As a consequence of the $\mathrm{Fe}^{3+}$ blockage, $\mathrm{NO}_{\mathrm{x}}$ conversion decreased upon and after propylene exposure. Later they found that the propylene poisoning effect can be significantly limited by using zeolite framework topologies with smaller pores,[62] which is also in agreement with recent findings on $\mathrm{Cu}$-zeolites by Ye et al.[63].

As shown in Chapter 2 BEA, MFI and CHA zeolite topologies are promising candidates for the $\mathrm{NH}_{3}$-SCR reaction. One of the main differences between these frameworks is the windows size that limits diffusion; especially for molecules such as HCs that may act like poisons to the active copper exchanged sites. The present chapter contains a comparison of $n$-decane influence on $\mathrm{NO}_{\mathrm{x}}$ conversion over Cu-Beta (BEA, 12-MR), Cu-ZSM-5 (MFI, 10-MR) and Cu-SSZ-13 (CHA, 8-MR) in the $\mathrm{NH}_{3}$-SCR reaction. $n$-decane is chosen as it is one of the possible components in diesel-exhaust. To make the comparison between the three zeolites, each of them are prepared with similar copper loads and acidities in terms of $\mathrm{Cu} / \mathrm{Al}$ and $\mathrm{Si} / \mathrm{Al}$ ratios.

To shed further light on the deactivation of small pore zeolites by HCs, propylene is used, as it enters the micropore system more readily than $n$-decane and is also a typical component in diesel exhaust. For this part of the study Cu-SSZ-13 and $\mathrm{Cu}-\mathrm{SAPO}-34$ are chosen in addition to the $\mathrm{Cu}$-Beta and $\mathrm{Cu}-\mathrm{ZSM}-5$. Each of them have the similar CHA framework topology, but silicoaluminophosphate SAPO-34 is more polar than the alumnisilicate SSZ-13 leading to differences in the deactivation behavior. The presence and amount of propylene adsorbed in the two catalysts are probed by adsorption experiments at various temperatures in an oxygen rich atmosphere. Afterwards the poisoning effect of propylene is explored by co-feeding propylene during $\mathrm{NH}_{3}$-SCR catalytic testing and the 
change in activities of $\mathrm{Cu}-\mathrm{SSZ}-13$ and $\mathrm{Cu}-\mathrm{SAPO}-34$ are compared at 250 and $300{ }^{\circ} \mathrm{C}$.

\subsection{Experimental}

Parent Beta and ZSM-5 zeolites were obtained from commercial suppliers. SSZ13 was prepared from a reaction synthesis gel with the following composition: $1.0 \mathrm{SiO}_{2}: 0.033 \mathrm{Al}_{2} \mathrm{O}_{3}: 0.5$ TMAdaOH : $0.5 \mathrm{HF}: 3 \mathrm{H}_{2} \mathrm{O}$

in a method very similar to the one reported earlier[64, 65] where TMAdaOH is the template N,N,N-trimethyladamantammonium hydroxide. The gel was prepared by dissolving aluminum isopropoxide ( $\geq 98 \%$, Aldrich) in tetraethyl orthosilicate ( $\geq 99 \%$, Aldrich) followed by adding template solution (25 wt. $\%$, Sacchem INC) slowly. The solution was then stirred mechanically until all products were hydrolyzed. Afterwards hydrofluoric acid (48 wt. \%, $\geq 99.99 \%$, Sigma-Aldrich) was added and again homogenized under mechanical stirring. Finally water was evaporated at $60{ }^{\circ} \mathrm{C}$ to reach the desired ratio. The resulting gel was then heated under rotation for 3 days at $150^{\circ} \mathrm{C}$ in a Teflon-lined steel autoclave, recovered by suction filtration, washed with plenty of demineralized water and dried at $100^{\circ} \mathrm{C}$. To remove the template, the zeolite was calcined at $580^{\circ} \mathrm{C}$ for $3 \mathrm{~h}$ prior to ion exchange.

Aqueous $\mathrm{Cu}^{2+}$ ion exchange of the parent zeolites was carried out with a copper(II)acetate solution $\left(250 \mathrm{~mL} / \mathrm{g}_{\text {zeolite }}\right)$ at different concentrations in order to obtain similar final copper loads: $3 \mathrm{mM}, 5 \mathrm{mM}$ and $10 \mathrm{mM}$ for $\mathrm{Cu}-\mathrm{SSZ}-13, \mathrm{Cu}-$ Beta and Cu-ZSM-5 were used respectively to obtain the desired copper loading. The slurry was continuously stirred for $24 \mathrm{~h}$ at room temperature and the exchanged zeolites were recovered by suction filtration, washed with demineralized water and dried overnight at $100{ }^{\circ} \mathrm{C}$ and further calcined at $500{ }^{\circ} \mathrm{C}$ in static air for $3 \mathrm{~h}$ in order to remove any residual acetate ligands.

Parent SAPO-34 with an average crystal size of $3.7 \mu \mathrm{m}$ was obtained from a commercial supplier and copper was introduced by aqueous ion exchange as well. The parent material was first calcined at $580{ }^{\circ} \mathrm{C}$ for $3 \mathrm{~h}$, then it was exchanged with a $40 \mathrm{mM}$ copper(II)acetate solution $\left(250 \mathrm{~mL} / \mathrm{g}_{\text {zeolite }}\right)$ for 5 days at room temperature with magnetic stirring. Afterwards the $\mathrm{Cu}-\mathrm{SAPO}-34$ was recovered in a similar manner as described for the zeolites above. For comparison of crystal sizes, a commercial Cu-SAPO-34 was used, which had an average crystal size of $1.0 \mu \mathrm{m}$. In all cases Cu-SAPO-34 was activated in $10 \% \mathrm{O}_{2}$ at $750{ }^{\circ} \mathrm{C}$ for one hour before any catalytic testing. 
Catalytic testing with $n$-decane was carried out in a fixed bed quartz reactor (i.d. $2 \mathrm{~mm}$ ) using $10 \mathrm{mg}$ catalyst $(150-300 \mu \mathrm{m}$ sieve fraction). The feed contained $500 \mathrm{ppm} \mathrm{NO}$ (ca. $430 \mathrm{ppm} \mathrm{NO}$ and $70 \mathrm{ppm} \mathrm{NO} \mathrm{N}_{2}$ ), $540 \mathrm{ppm} \mathrm{NH} \mathrm{NH}_{3}, 10$ $\% \mathrm{O}_{2}$, and $3 \% \mathrm{H}_{2} \mathrm{O}$ and ca. $200 \mathrm{ppm} n$-decane, balanced with $\mathrm{N}_{2}$ to a total flow rate of $450 \mathrm{NmL} / \mathrm{min}$. The water was introduced by an HPLC pump through an evaporator and the $n$-decane by bubbling the feed through a bubble flask kept at $0{ }^{\circ} \mathrm{C}$. Because of the free volume in the bubble flask some NO reacted to form $\mathrm{NO}_{2}$. Conversions without $n$-decane was therefore carried out with an empty bubble flask to obtain a similar $\mathrm{NO}_{2} / \mathrm{NO}$ ratio. It should be noted that the high amount of $\mathrm{NO}_{2}$ enhances the conversion due to the fast SCR reaction. The outlet gas was analyzed by a Gasmet CR4000 FTIR analyzer with a liquid nitrogen cooled MCT detector.

Catalytic testing with propylene was carried out in a similar setup with $10 \mathrm{mg}$ catalyst (150-300 $\mu \mathrm{m}$ sieve fraction), but without the bubble flask and with a Gasmet CX4000 FTIR analyzer equipped with a Peltier cooled MCT detector. The feed in this case contained $500 \mathrm{ppm} \mathrm{NO}$ (ca. $493 \mathrm{ppm} \mathrm{NO}$ and $7 \mathrm{ppm}$ $\mathrm{NO}_{2}$ ), $530 \mathrm{ppm} \mathrm{NH}_{3}, 10 \% \mathrm{O}_{2}$, and $3 \% \mathrm{H}_{2} \mathrm{O}$, or in special cases without $\mathrm{H}_{2} \mathrm{O}$, and $250 \mathrm{ppm}$ propylene, balanced with $\mathrm{N}_{2}$ to a total flow rate of $450 \mathrm{NmL} / \mathrm{min}$. All flows were controlled by gas or liquid mass flow controllers.

Propylene uptake at various temperatures were measured on a Netzsch STA 409 thermo gravimetric analyzer equipped with a gas flow system. Before propylene uptake the samples were calcined in the apparatus to remove any adsorbates. Then the sample temperature was lowered to the desired adsorption temperature whereafter propylene was admitted for a predetermined amount of time. Afterwards the sample was heated to $550{ }^{\circ} \mathrm{C}$ to remove any adsorbates and the procedure repeated at the next desired propylene adsorption temperature. The flow was kept constant at $100 \mathrm{NmL} / \mathrm{min}$ with a composition of $10 \% \mathrm{O}_{2}$ in nitrogen and 2000 ppm propylene during adsorption.

\subsection{Results and Discussion}

Cu-Beta, Cu-ZSM-5 and Cu-SSZ-13 with 12-MR, 10-MR and 8-MR window sizes respectively, were successfully prepared with similar $\mathrm{Cu} / \mathrm{Al}$ and $\mathrm{Si} / \mathrm{Al}$ ratios (see Table 3.1) to avoid any discrepancies due to different amounts of acidity and active sties. 
Table 3.1: Chemical compositions and window size (given in number of T-atoms in the ring and dimensionality with the number of $*$ ) of prepared samples for $\mathrm{HC}$ poisoning studies

\begin{tabular}{lccc}
\hline Sample & $\mathrm{Cu} / \mathrm{Al}$ & $\mathrm{Si} / \mathrm{Al}$ & window size \\
\hline Cu-Beta & 0.44 & 13.0 & $12^{* * *}$ \\
Cu-ZSM-5 & 0.43 & 12.4 & $10^{* * *}$ \\
Cu-SSZ-13 & 0.45 & 13.1 & $8^{* * *}$ \\
\hline
\end{tabular}

\subsubsection{Effect of window size}

The effect of window size on $\mathrm{NO}_{\mathrm{x}}$ conversion under the presence of $n$-decane was studied at $300{ }^{\circ} \mathrm{C}$ and the results are shown in Figure 3.1. Before the addition of $n$-decane $\mathrm{NO}_{\mathrm{x}}$ conversion was above $99 \%$ over all $\mathrm{Cu}$-zeolites. Upon addition of the $\mathrm{HC}$ (dotted grey line in Figure 3.1) the three Cu-zeolites behave differently. The $\mathrm{NO}_{\mathrm{x}}$ conversion over $\mathrm{Cu}$-Beta drops immediately and reaches a steady state around $17 \%$. Less deactivation compared to the Beta system is seen over the Cu-ZSM-5 zeolite. Steady state conditions are not reached upon $n$-decane exposure in this case as the deactivation is slower than for $\mathrm{Cu}$-Beta and at the end of the experiment $56 \% \mathrm{NO}_{\mathrm{x}}$ conversion is reached. As can be seen in Figure 3.1, no noticeable effect of the presence of $n$-decane is seen over $\mathrm{Cu}-\mathrm{SSZ}-13$ on the $\mathrm{NO}_{\mathrm{x}}$ conversion and about $99 \%$ conversion is maintained throughout the entire course of the experiment.

The extent of deactivation upon addition of $n$-decane clearly demonstrates the effect of window size on $\mathrm{NO}_{\mathrm{x}}$ conversion when $n$-decane is present in the feed. This is consistent with the diffusion of $n$-decane into the microporous system of the zeolites. In the Beta zeolite $n$-decane enter the pore system easily and the catalyst deactivates rapidly. In ZSM-5 diffusion of $n$-decane is slower and the deactivation occur less rapid. Since the window in SSZ-13 $(3.8 \times 3.8 \AA)$ is smaller than the kinetic diameter of $n$-alkanes $(4.3 \AA),[66]$ local repulsion effects are likely to occur and as a consequence only little or no $n$-decane enters the pore system and therefore no influence of $n$-decane on $\mathrm{NO}_{\mathrm{x}}$ conversion is seen over this small-pore zeolite.

When $n$-decane was removed from the feed the $\mathrm{NO}_{\mathrm{x}}$ conversion returned to original values over $\mathrm{Cu}$-ZSM-5 whereas $\mathrm{Cu}$-Beta required heating to $500{ }^{\circ} \mathrm{C}$ in the presence of oxygen to regain its original catalytic activity. Extensive coking could in this case be a reasonable explanation. 

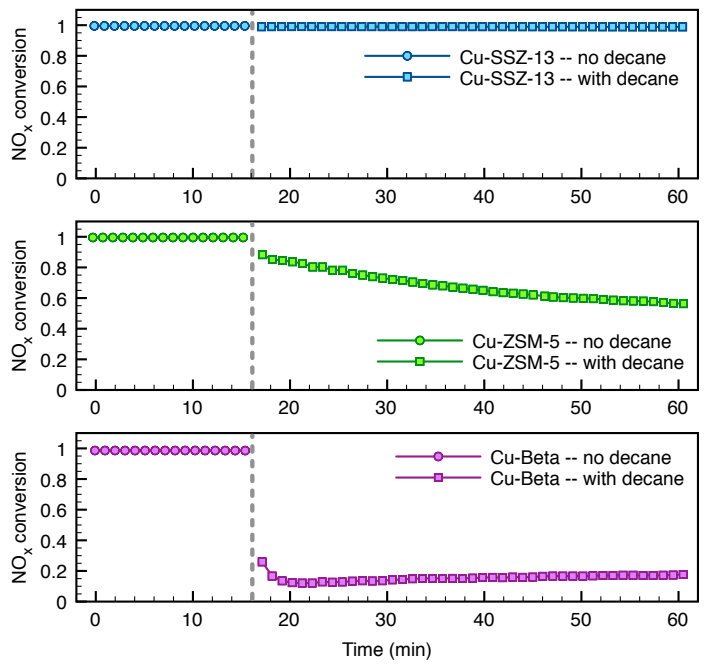

Figure 3.1: $\mathrm{NOx}$ conversion at $300{ }^{\circ} \mathrm{C}$ during exposure to $n$-decane as a function of time for Cu-SSZ-13 (8-MR windows), Cu-ZSM-5 (10-MR windows) and $\mathrm{Cu}-$ Beta $\left(12-\mathrm{MR}\right.$ windows) zeolites. Conditions were: $500 \mathrm{ppm} \mathrm{NO}_{\mathrm{x}}$ (ca.

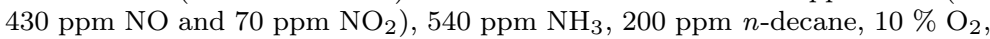
$2 \% \mathrm{H}_{2} \mathrm{O}$ with $\mathrm{N}_{2}$ as balance to $450 \mathrm{NmL} / \mathrm{min}$ using $10 \mathrm{mg}$ catalyst

The behavior during and after $n$-decane exposure of the three zeolites illustrates the window size effect on $\mathrm{HC}$ deactivation: $\mathrm{Cu}-\mathrm{SSZ}-13$ with $8-\mathrm{MR}$ windows is not affected, Cu-ZSM-5 with 10-MR windows is effected to some extent and $\mathrm{Cu}$-Beta with $12-\mathrm{MR}$ windows is severely affected. The observation that the deactivation of $n$-decane is reversible on $\mathrm{Cu}$-ZSM-5, but $\mathrm{Cu}$-Beta requires heating to $500{ }^{\circ} \mathrm{C}$ in order to recover initial $\mathrm{NO}_{\mathrm{x}}$ conversion suggests that the adsorption of $n$-decane or products thereof e.g. oxygenates, cyanate-type adsorbates or coke occurs more extensively or in a different manner on $\mathrm{Cu}$-Beta than on $\mathrm{Cu}-\mathrm{ZSM}-5$.

A similar window size effect is also seen when propylene was added to the feed instead of the $n$-decane. This is shown for the same Cu-SSZ-13, Cu-ZSM-5 and $\mathrm{Cu}$-Beta catalyst in Figure 3.2. In this case even $\mathrm{Cu}-\mathrm{SSZ}-13$ is affected as the propylene is able to enter the 8 -MR pore system. Interestingly, there seem to be a very fast deactivation as seen by the fast decrease in observed $\mathrm{NO}_{\mathrm{x}}$ conversion followed by a slower deactivation seen by the additional decrease 
over a prolonged period of time. Whereas the fast deactivation is present to an similar extent over all catalysts, the slower deactivation part is not visible for $\mathrm{Cu}-\mathrm{SSZ}-13$. From these observations alone, it suggests two different deactivation mechanisms. For practical applications, the results indicate that regeneration of catalysts with larger window sizes require either higher temperatures or prolonged regeneration times compared to zeolites with smaller window sizes.
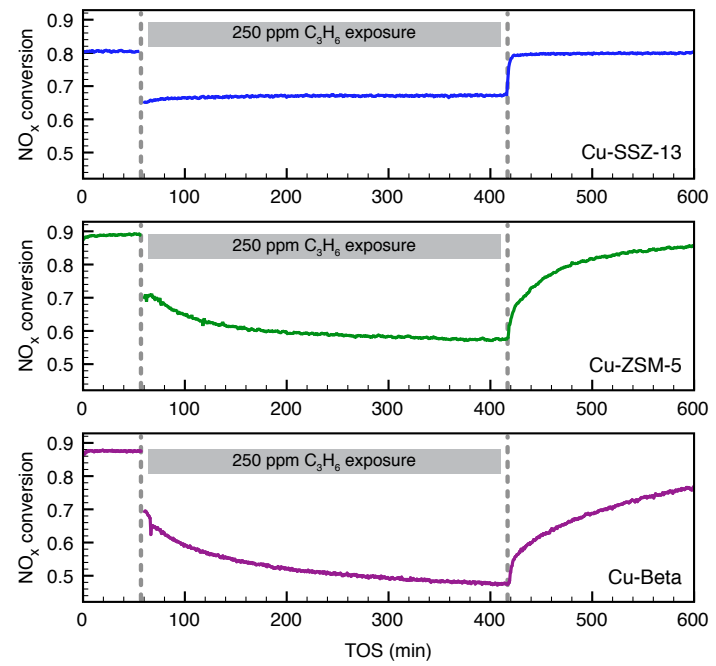

Figure 3.2: $\mathrm{NO}_{\mathrm{x}}$ conversion before, during and after exposure to propylene over Cu-SSZ-13 (top), Cu-ZSM-5 (middle) and Cu-Beta (bottom) at $300{ }^{\circ} \mathrm{C}$. Conditions were: $500 \mathrm{ppm} \mathrm{NO}, 530 \mathrm{ppm} \mathrm{NH}_{3}, 250 \mathrm{ppm}$ propylene, $10 \% \mathrm{O}_{2}$, $3 \% \mathrm{H}_{2} \mathrm{O}$ and with $\mathrm{N}_{2}$ as balance to $450 \mathrm{NmL} / \mathrm{min}$ using $10 \mathrm{mg}$ catalyst

\subsubsection{Poisoning of small-pore catalysts: effect of frame- work polarity}

As $n$-decane was seen not to affect the $\mathrm{NO}_{\mathrm{x}}$ conversion to a measurable extent on the CHA type catalyst $\mathrm{Cu}-\mathrm{SSZ}-13$, propylene was chosen to study the differences in HC-poisoning between aluminosilicate Cu-SSZ-13 and silicoaluminophosphate $\mathrm{Cu}-\mathrm{SAPO}-34$ in addition to the already obtained results. Even though the two materials have the same CHA topology, SAPO-34 is more polar than the high silica zeolite SSZ-13 due to the nature of the chemical bonds 


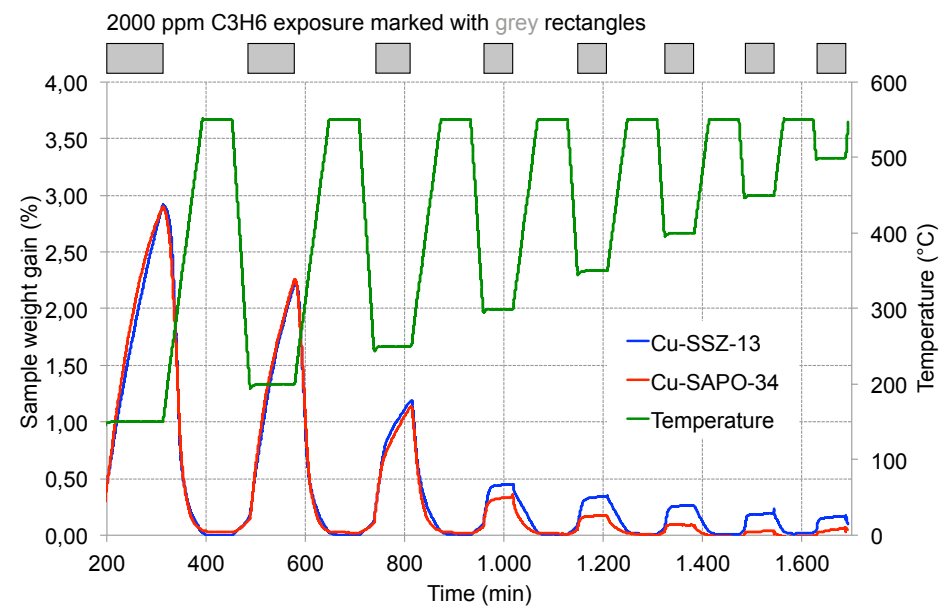

Figure 3.3: Sample weight gain in percentage at various temperatures and desorption (at $550{ }^{\circ} \mathrm{C}$ ) of propylene for Cu-SSZ-13 and Cu-SAPO-34. The gas composition during the experiment was $10 \% \mathrm{O}_{2}$ in $\mathrm{N}_{2}$ and $2000 \mathrm{ppm}$ propylene as indicated in the Figure

and the difference in electronegativity between the framework atoms in the two frameworks.[67]

The uptake of propylene in $\mathrm{Cu}-\mathrm{SSZ}-13$ and $\mathrm{Cu}-\mathrm{SAPO}-34$ was initially measured at various temperatures in an oxygen rich atmosphere. The results of the propylene uptake measured by TGA is shown in Figure 3.3. Between each adsorption temperature the catalyst was regenerated at $550{ }^{\circ} \mathrm{C}$, which is shown to be sufficient to burn off propylene and any products thereof as the weight of the sample returns to the original before propylene exposure. This observation has some practical value because it shows that the catalyst may in principle be regenerated by simply raising the temperature to $550{ }^{\circ} \mathrm{C}$.

From Figure 3.3 the propylene uptake at 150 to $250{ }^{\circ} \mathrm{C}$ is furthermore seen to be similar for both $\mathrm{Cu}-\mathrm{SSZ}-13$ and $\mathrm{Cu}$-SAPO-34 despite the different framework polarity and copper content. This indicate a simple and unselective adsorption behavior and adsorption equilibrium is seen not to be reached within the time of the adsorption cycles. Above $250{ }^{\circ} \mathrm{C}$, differences between the two 
materials become more pronounced and equilibrium adsorption of propylene or products thereof is reached as seen by the flat plateau in the weight gain curve. Above this temperature $\mathrm{Cu}-\mathrm{SSZ}-13$ is seen to adsorb more propylene than $\mathrm{Cu}$ SAPO-34. Raising the temperature further; the difference between adsorption of propylene (and products thereof) on Cu-SSZ-13 and Cu-SAPO-34 increases even further as a consequence of the difference in chemical composition between the two materials and possibly also the difference in copper speciation.

To compare Cu-SAPO-34 and Cu-SSZ-13 pseudo-first order rate constants with respect to $\mathrm{NO}_{\mathrm{x}}$ in the $\mathrm{NH}_{3}$-SCR reaction were normalized to the steady state activity before addition of propylene to the feed. This was calculated according to equation 3.1 assuming similar pressure drops and pseudo-first order kinetics:

$$
\frac{k_{t}}{k_{t=0}}=\frac{\frac{-F_{\text {total }, 0}}{W_{\text {cat }} \cdot P_{t}} \ln \left(1-X_{t}\right)}{\frac{-F_{\text {total }, 0}}{W_{c a t} \cdot P_{t=0}} \ln \left(1-X_{t=0}\right)}=\frac{\ln \left(1-X_{t}\right)}{\ln \left(1-X_{t=0}\right)}
$$

where $F_{\text {total, } 0}$ is the total inlet molar flow rate, $P$ the pressure, $W_{\text {cat }}$ the catalyst amount and $X$ the $\mathrm{NO}_{\mathrm{x}}$ conversion. The subscript $t$ refers to a given time and $t=0$ to the reference time (taken here under steady state conversion before exposure to HCs). Compared to the conversion observed in the experiments with $n$-decane, the conversion was lower in this case because less $\mathrm{NO}_{2}$ was fed to the reactor, which is known to speed up the overall reaction due to the fast $\mathrm{SCR}$ reaction.

The influence of propylene on Cu-SSZ-13 and Cu-SAPO-34 activity calculated according to equation 3.1 in the $\mathrm{NH}_{3}-\mathrm{SCR}$ reaction at 300 and $250{ }^{\circ} \mathrm{C}$ is shown in Figure 3.4. From the relative change in activity when propylene is added to the feed it is seen that both Cu-SSZ-13 and Cu-SAPO-34 are affected by propylene at 250 as well as at $300{ }^{\circ} \mathrm{C}$. It is also clear that during propylene exposure SAPO-34 is less influenced than Cu-SSZ-13 at both temperatures tested. This behavior is most pronounced at $300{ }^{\circ} \mathrm{C}$ and becomes more similar at $250{ }^{\circ} \mathrm{C}$ as could be expected from the propylene uptake earlier shown in Figure 3.3. Additionally it may be noted that the original catalytic activity is not regained at $250{ }^{\circ} \mathrm{C}$ for neither $\mathrm{Cu}-\mathrm{SSZ}-13$ and $\mathrm{Cu}-\mathrm{SAPO}-34$ when propylene is switched off, and Cu-SAPO-34 is more affected. This behavior changes at $300{ }^{\circ} \mathrm{C}$ where all activity is regained for $\mathrm{Cu}-\mathrm{SAPO}-34$, but not for $\mathrm{Cu}-\mathrm{SSZ}-13$. The reason for this behavior remains unclear, but can most likely be related to the higher framework polarity as well. 

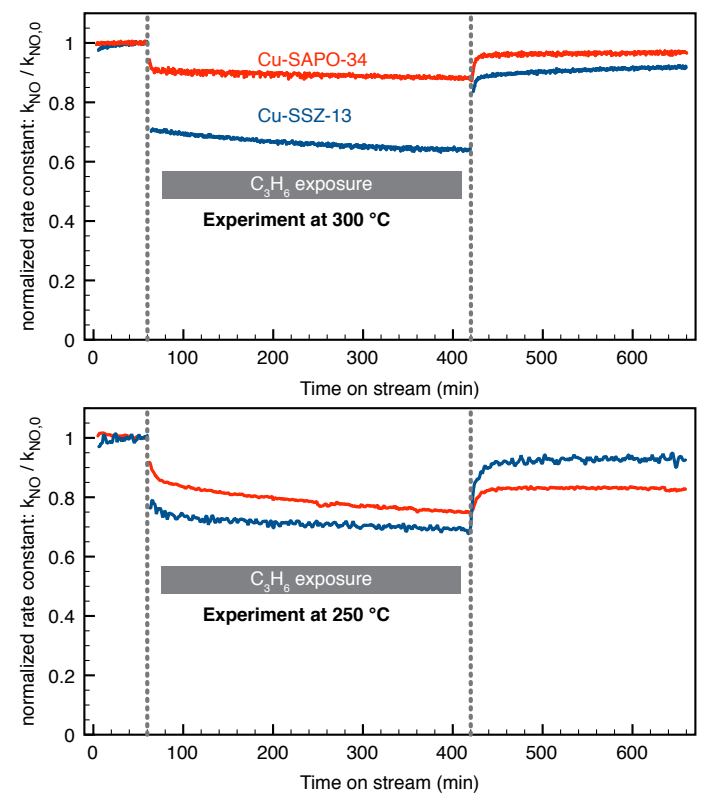

Figure 3.4: Normalized rate constants to initial steady state measured at 300 (top) and 250 (bottom) ${ }^{\circ} \mathrm{C}$ during exposure to propylene as a function of time for $\mathrm{Cu}-\mathrm{SSZ}-13$ given in blue (apolar framework and $2.4 \mathrm{wt} . \% \mathrm{Cu}$ ) and $\mathrm{Cu}-\mathrm{SAPO}-34$ given in red (polar framework and $1.2 \mathrm{wt} . \% \mathrm{Cu}$ ) both with 8-MR windows. Conditions were: $500 \mathrm{ppm} \mathrm{NO}, 530 \mathrm{ppm} \mathrm{NH}_{3}, 250 \mathrm{ppm}$ propylene, $10 \% \mathrm{O}_{2}, 3 \% \mathrm{H}_{2} \mathrm{O}$ and with $\mathrm{N}_{2}$ as balance to $450 \mathrm{NmL} / \mathrm{min}$ using $10 \mathrm{mg}$ catalyst

As it was earlier observed the deactivation by propylene, especially at $250{ }^{\circ} \mathrm{C}$, seem to proceed first by a very rapid drop in activity and afterwards followed by a slow decrease; again an indication of two different mechanisms. One explanation for the quick drop in activity is the initial adsorption of propylene on the surface of the crystals where it could block the pore entrances for reactants. If this is the case any change in average crystal size of the catalyst should change the extent of the initial drop in activity. To disprove this hypothesis two $\mathrm{Cu}$-SAPO-34 samples with similar $\mathrm{Cu}$-contents, but different crystal sizes were tested at $300{ }^{\circ} \mathrm{C}$ for the influence of co-feeding propylene during the $\mathrm{NH}_{3}$-SCR reaction. The results are shown in Figure 3.5. As can be seen the change in 
crystal size from $3.7 \mu \mathrm{m}$ to $1.0 \mu \mathrm{m}$ does not have an effect on the change in activity. Instead it must be concluded that the difference in the quick deactivation between $\mathrm{Cu}-\mathrm{SSZ}-13$ and $\mathrm{Cu}-\mathrm{SAPO}-34$ must be due to either the difference in chemical composition of the framework or the change in copper speciation between these two materials.

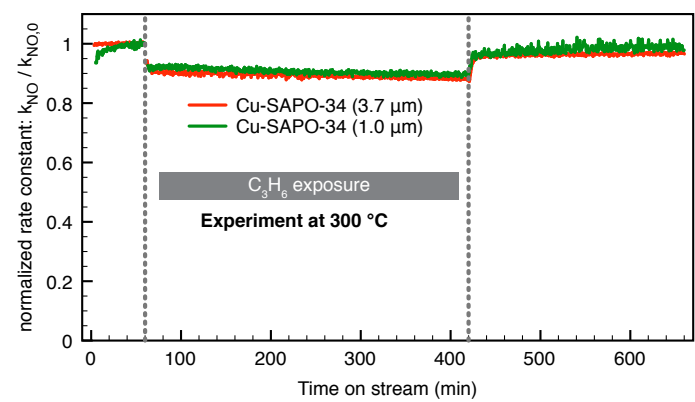

Figure 3.5: The influence of adding propylene to the feed during $\mathrm{NH}_{3}$-SCR at $300{ }^{\circ} \mathrm{C}$ over $\mathrm{Cu}$-SAPO-34 with average crystal sizes of 1.0 and $3.7 \mu \mathrm{m}$. Conditions were: $500 \mathrm{ppm} \mathrm{NO}, 530 \mathrm{ppm} \mathrm{NH}_{3}, 250 \mathrm{ppm}$ propylene, $10 \% \mathrm{O}_{2}$, $3 \% \mathrm{H}_{2} \mathrm{O}$ and with $\mathrm{N}_{2}$ as balance to $450 \mathrm{NmL} / \mathrm{min}$ using $10 \mathrm{mg}$ catalyst

\subsection{Summary and Conclusions}

$\mathrm{Cu}-\mathrm{Beta}, \mathrm{Cu}-\mathrm{ZSM}-5$ and $\mathrm{Cu}-\mathrm{SSZ}-13$ zeolites were prepared with similar copper loads and $\mathrm{Si} / \mathrm{Al}$ ratios to investigate the influence of hydrocarbons on their performance as catalysts in the $\mathrm{NH}_{3}$-SCR reaction. These three zeolite frameworks have different window sizes: $12-\mathrm{MR}, 10-\mathrm{MR}$ and 8 -MR respectively. In the present chapter it was shown that upon addition of $n$-decane, which is one of the major hydrocarbon components in the exhaust from internal combustion engines, to the feed, the poisoning of Cu-zeolites in the $\mathrm{NH}_{3}$-SCR reaction is largely dependent on the window size in the zeolite structure.

The differences in resistance can be explained by the amount of hydrocarbons that are allowed to diffuse into the zeolite microporous system. In this way small pores hinder the diffusion of $\mathrm{HCs}$, so that adsorption onto the active $\mathrm{Cu}$-sites can be avoided. In accordance with this explanation we observed that $\mathrm{Cu}$-Beta (12-MR) was severely and irreversibly deactivated by $n$-decane, Cu-ZSM- 5 was reversibly affected and Cu-SSZ-13 not affected at $300{ }^{\circ} \mathrm{C}$. A similar trend for 
these three zeolites was also observed with propylene that was seen to also affect $\mathrm{Cu}-\mathrm{SSZ}-13$, but still to a smaller extent compared to the the zeolites with larger window sizes.

The effect of framework polarity on hydrocarbon resistance was further investigated in the presence of propylene over small pore catalysts Cu-SSZ-13 and $\mathrm{Cu}-\mathrm{SAPO}-34$. As a consequence of the smaller size of propylene it can enter the pore system of the small-pore zeolite easier than $n$-decane, which allowed us to study the effect of framework polarity on propylene poisoning in the $\mathrm{NH}_{3}$-SCR reaction.

Propylene uptake measurements showed that between 150 and $250{ }^{\circ} \mathrm{C} \mathrm{Cu}$-SSZ13 and $\mathrm{Cu}-\mathrm{SAPO}-34$ take up similar amounts of propylene, but above $250{ }^{\circ} \mathrm{C}$ $\mathrm{Cu}-\mathrm{SAPO}-34$ take up less propylene than $\mathrm{Cu}-\mathrm{SSZ}-13$. This was suggested to be a consequence of the difference in framework polarity. Results of catalytic conversion of $\mathrm{NO}_{\mathrm{x}}$ with $\mathrm{NH}_{3}$ in the presence of propylene at $300{ }^{\circ} \mathrm{C}$ also showed that $\mathrm{Cu}-\mathrm{SSZ}-13$ is indeed more affected than Cu-SAPO-34. This was also the case at $250{ }^{\circ} \mathrm{C}$, but to a somewhat smaller extent.

Overall, as shown in this chapter, $\mathrm{Cu}-\mathrm{CHA}$ catalysts show a high resistance towards hydrocarbon poisoning during $\mathrm{NH}_{3}$-SCR. Although differences in activity could be observed when propylene was co-fed most of the activity could be recovered by simply removing the propylene from the feed. Additionally, all propylene and products thereof could easily be removed at higher temperatures (e.g. $550{ }^{\circ} \mathrm{C}$ ), which the catalyst will normally experience during operation.

\subsection{Future work}

In order to further elucidate the mechanism of deactivation from hydrocarbons on $\mathrm{Cu}$-zeolite $\mathrm{NH}_{3}$-SCR performance it would be relevant to investigate the nature of the adsorbed species by methods such as FTIR, NMR or Raman. Especially using FTIR techniques it will be possible to comment further on the identity of these species under operating conditions. Based on this information it should in combination with e.g. DFT calculations be possible to comment further on why $\mathrm{Cu}-\mathrm{SAPO}-34$ is less influenced by propylene than $\mathrm{Cu}-\mathrm{SSZ}-13$ at higher temperatures. 
CHAPTER 4

\section{Thermal activation of Cu-SAPO-34: migration of Cu-ions and influence on $\mathrm{NH}_{3}-\mathrm{SCR}$ performance}

This chapter is adapted from the publication:

P.N.R. Vennestrøm, A. Katerinopoulou, R.R. Tiruvalam, A. Kustov, P.G. Moses, P. Concepcion, A. Corma, "Migration of $\mathrm{Cu}$ Ions in SAPO-34 and Its Impact on Selective Catalytic Reduction of $\mathrm{NO}_{\mathrm{x}}$ with $\mathrm{NH}_{3}$ ", ACS Catal., 2013, 3, 2158

\subsection{Introduction}

For automotive diesel exhaust treatment one of the most promising practical solutions to remove soot particles, as well as $\mathrm{NO}_{\mathrm{x}}$, is the combination of diesel particulate filters with $\mathrm{NH}_{3}$-SCR catalysts into one combined block. When the filter is clogged by particulate matter a regeneration becomes necessary and active regenerations are typically carried out at temperatures above $650{ }^{\circ} \mathrm{C}$ and even up to $750{ }^{\circ} \mathrm{C}$ (see Chapter 1 ). This requires very high hydrothermal stability of the SCR catalyst. Even though zeolite catalysts are preferred over vanadia based catalyst due to their thermal stability, one of the major challenges still remains: that is the hydrothermal stability when such high temperature excursions are possible. This is particularly challenging for copper exchanged zeolites 
that typically loose more catalytic $\mathrm{NH}_{3}$-SCR activity than their iron equivalents under hydrothermal conditions.[68].

As shown in Chapter 2 and recently reported by Fickel et al. small-pore zeolites show superior hydrothermal stability compared to other zeolites. [33] Especially copper exchanged SSZ-13 with the CHA framework topology has attracted substantial attention,[36, 42, 51, 69, 70] and have within the last few years also become a commercialized catalyst. [71-73]

The CHA topology consists of a three-dimensional porous system with cavities and small-pore 8-member-ring windows with a free diameter of $3.8 \times 3.8$ A.[9] The high silica zeolite with CHA topology is usually referred to as SSZ$13(\mathrm{~T}$-atoms $=\mathrm{Si}+\mathrm{Al})$ and its silicoaluminophosphate $(\mathrm{T}$-atoms $=\mathrm{Si}+\mathrm{Al}+\mathrm{P})$ analog is named SAPO-34. The reason for the increased hydrothermal stability of SSZ-13 has been suggested to be a consequence of the small windows, where detached aluminum moieties cannot exit the pores of the material because of their larger kinetic diameter.[33] Similar features are also valid for Cu-SAPO-34 as it has the same framework topology. SAPO-34 also has the advantage of already being a commercialized catalyst due to its use in the methanol to olefin reaction.[74, 75] Furthermore the organic structure directing agent used in the synthesis of SAPO-34 is less expensive than the one used for SSZ-13. For these reasons $\mathrm{Cu}-\mathrm{SAPO}-34$ has also been tested in the $\mathrm{NH}_{3}-\mathrm{SCR}$ reaction, but has received significantly less attention than $\mathrm{Cu}-\mathrm{SSZ}-13$.

In the present chapter copper is introduced by aqueous ion exchange into SAPO34 samples with different crystal sizes to show that obtainable copper loads depend on the crystal size and not on silicon content or acidity. The exchange leads to an inhomogenous distribution of copper species mostly located in the outer regions of the individual crystals. To redistribute the copper thermal treatments at increasing temperature up to $750{ }^{\circ} \mathrm{C}$ are used. To follow the migration of copper species XPS and Auger spectroscopy on Cu-SAPO-34 is studied and compared to results obtained on Cu-SSZ-13. Additionally, characteristic X-ray intensity maps are used to show the initial and final location of copper before and after thermal activation. The results of catalytic experiments are furthermore compared to those over $\mathrm{Cu}-\mathrm{SSZ}-13$ before and after thermal treatments, which clearly show the importance of obtaining a homogenous copper distribution. 


\subsection{Experimental}

SAPO-34 zeotypes were obtained from various commercial suppliers with different crystal sizes.

SSZ-13 was prepared from a reaction synthesis gel with the following composition:

$1.0 \mathrm{SiO}_{2}: 0.033 \mathrm{Al}_{2} \mathrm{O}_{3}: 0.5$ TMAdaOH : $0.5 \mathrm{HF}: 3 \mathrm{H}_{2} \mathrm{O}$

in a method very similar to the one reported earlier $[64,65]$ where TMAdaOH is the template $\mathrm{N}, \mathrm{N}, \mathrm{N}$ - trimethyladamantammonium hydroxide. The gel was prepared by dissolving aluminum isopropoxide ( $\geq 98 \%$, Aldrich) in tetraethyl orthosilicate ( $\geq 99 \%$, Aldrich) followed by adding template solution (25 wt. $\%$, Sacchem INC) slowly. The solution was then stirred mechanically until all products were hydrolyzed. Afterwards hydrofluoric acid (48 wt. \%, $\geq 99.99 \%$, Sigma- Aldrich) was added and again homogenized under mechanical stirring. Finally water was evaporated at $60{ }^{\circ} \mathrm{C}$ to reach the desired ratio. The resulting gel was then heated under rotation for 3 days at $150^{\circ} \mathrm{C}$ in a Teflon-lined steel autoclave, recovered by vacuum filtration, washed with an excess of demineralized water and dried at $100{ }^{\circ} \mathrm{C}$. To remove the template, the zeolite was calcined at $580{ }^{\circ} \mathrm{C}$ for $3 \mathrm{~h}$. All samples were prepared by aqueous ion exchange with copper(II)acetate monohydrate solutions (Sigma-Aldrich $\geq 99.0 \%$ ), washed with demineralized $\mathrm{H}_{2} \mathrm{O}$ and dried at $100{ }^{\circ} \mathrm{C}$ for a minimum of $12 \mathrm{~h}$ before use.

For all samples $\mathrm{Cu}, \mathrm{Si}, \mathrm{Al}$ and $\mathrm{P}$ contents were measured on samples using calibrated ICP-OES.

Micropore volumes were measured by $\mathrm{N}_{2}$ physisorption at $-196{ }^{\circ} \mathrm{C}$ on a $\mathrm{Mi}$ cromeritics ASAP-2000 apparatus after the samples were pretreated at $150{ }^{\circ} \mathrm{C}$ under vacuum.

Crystal sizes were determined by electroaccoustic methods in a Colloidal Dynamics Acoustosizer IIS instrument and confirmed by SEM microscopy recorded on a JEOL JSM-6700F instrument using an electron energy of $15 \mathrm{keV}$.

Crystallinity and phases were measured by X-ray diffraction on a multisample PANalytical X'Pert diffractometer using the characteristic $\mathrm{Cu} \mathrm{K} \alpha$ wavelength $(1.542 \AA)$.

X-ray photoelectron and Auger spectra were collected using a SPECS spectrometer with a 150 MCD-9 detector and using a non monochromatic AlK $\alpha$ (1486.6eV) X-Ray source. Spectra were recorded using an analyzer pass energy of $30 \mathrm{eV}$, an X-ray power of $200 \mathrm{~W}$ under operating pressure of $10^{-9}$ mbar. During data processing of the XPS spectra, binding energy (BE) values were referenced to Si2p peak $(102.5 \mathrm{eV})$. Spectra treatment were afterwards carried out using the CASA software package.[76] 
X-Ray intensity maps were recorded on a JEOL JXA8530F Hyperprobe operated at $15 \mathrm{kV}, 10 \mathrm{nA}$ and approximately $2 \mathrm{~nm}$ beam diameter with Wavelength Dispersive Spectroscopy (WDS). Characteristic X-Rays were analyzed on a TAP crystal for $\mathrm{Al}$ and PET crystal for Si simultaneously with $\mathrm{Cu}$ on a LIFH crystal. P was later analyzed on a LIF crystal for some of the Cu-SAPO-34 crystals. Maps were recorded by beam rastering on areas up to $15 \mu \mathrm{m}^{2}$ with $10 \mathrm{~ms}$ dwell time averaged over 4 acquisitions. The maps were binned by a $2 \times 2$ matrix by using the software ImageJ. A liquid nitrogen trap was used on the top of the sample to avoid contamination. Samples were prepared by embedding the crystals in epoxy and cutting the embedded surface by ultramicrotomy. Prior to analysis a 20-25 $\mathrm{nm}$ thick carbon layer was sputtered on the samples to avoid charging. Maps were recorded on more than 10 randomly chosen crystals. Beam damage due to material instability under the beam could be minimized using low dwell times and averaging over several accumulations. Beam tracking was also applied to avoid lateral drift, which would otherwise have affected the spatial resolution.

Catalytic tests and pretreatments were performed in a fixed bed reactor (i.d. $2 \mathrm{~mm}$ ) packed with 10,20 or $40 \mathrm{mg}$ catalyst (150-300 $\mu \mathrm{m}$ sieve fraction) on a bed of quartz wool. $\mathrm{NH}_{3}$-SCR activity measurements tests were performed under steady states conditions with a total flow of $300 \mathrm{NmL} / \mathrm{min}$ containing 500 ppm NO, 530 ppm $\mathrm{NH}_{3}, 10 \% \mathrm{O}_{2}$ and $5 \% \mathrm{H}_{2} \mathrm{O}$ balanced with $\mathrm{N}_{2}$ all admitted through calibrated mass (and liquid) flow controllers. Exit gases were analyzed by a Gasmet CX4000 FTIR analyzer equipped with a Peltier cooled MCT detector.

\subsection{Results and discussion}

In an effort to better understand the ion exchange properties of SAPO-34 four different parent samples were obtained. Each of the samples was divided in two portions. One batch was then ion exchanged with an aqueous solution of $5 \mathrm{mM}$ $\mathrm{Cu}^{2+}$ and the other ion exchanged with $125 \mathrm{mM}$. The crystal size of the four parent SAPO-34 varied from 1 to $11 \mu \mathrm{m}$, and contained almost similar amounts of silicon incorporated in the framework (see Table 4.1) leading to similar number of acid sites.

Under similar ion exchange conditions the obtained copper loads decreased monotonically with increasing average crystal size. Thus, obtainable copper loads appeared not to be related to the number of acid sites, measured by the 
ammonia capacity, nor amount of silicon in the range tested here, but instead it correlates to the crystal size. Increasing the concentration from $5 \mathrm{mM}$ to 125 $\mathrm{mM}$ lead to increase, in obtainable copper loading, but not in a proportional manner. Further increase of the ion exchange time or concentration (the latter was only possible by also changing the type of copper salt due to insufficient solubility) did not yield further increase in the copper loading (not shown). For SAPO-34 with an average crystal size of $3.7 \mu \mathrm{m}$ the obtained copper content increased from $11.6 \cdot 10^{-3}$ to $13.7 \cdot 10^{-3} \mathrm{Cu}$ atoms per tetrahedral framework atom $(\mathrm{Si}+\mathrm{Al}+\mathrm{P})$ when the time was increased from $24 \mathrm{~h}$ to $120 \mathrm{~h}$. The latter corresponds to 1.2 wt. $\%$ of $\mathrm{Cu}$ in the final $\mathrm{Cu}-\mathrm{SAPO}-34$.

Table 4.1: Average crystal sizes, $\mathrm{Si}$ content and $\mathrm{NH}_{3}$ capacity of parent SAPO-34 materials as well as atomic ratios of $\mathrm{Cu}$ to framework atoms after aqueous ion exchange (IE) with 5 or $125 \mathrm{mM} \mathrm{Cu}^{2+}$ concentrations for $24 \mathrm{~h}$ at RT. Crystal sizes were determined by SEM and electro-accoustic methods and the $\mathrm{NH}_{3}$ capacity measured after adsorption and flushing at $150{ }^{\circ} \mathrm{C}$ followed by desorption up to $600{ }^{\circ} \mathrm{C}$

\begin{tabular}{ccccc}
\hline $\begin{array}{c}\text { Crystal size } \\
(\mu \mathrm{m})\end{array}$ & $\begin{array}{c}\mathrm{Si} /(\mathrm{Si}+\mathrm{Al}+\mathrm{P}) \\
-\end{array}$ & $\begin{array}{c}\mathrm{NH}_{3} \text { capacity } \\
(\mu \mathrm{mol} / \mathrm{g})\end{array}$ & $\begin{array}{c}\mathrm{IE} 5 \mathrm{mM} \\
\mathrm{Cu} /(\mathrm{Si}+\mathrm{Al}+\mathrm{P})\end{array}$ & $\begin{array}{c}\mathrm{IE} 125 \mathrm{mM} \\
\mathrm{Cu} /(\mathrm{Si}+\mathrm{Al}+\mathrm{P})\end{array}$ \\
\hline 1.0 & 0.10 & 915 & $7.88 \cdot 10^{-3}$ & $14.69 \cdot 10^{-3}$ \\
3.7 & 0.14 & 985 & $5.00 \cdot 10^{-3}$ & $11.59 \cdot 10^{-3}$ \\
6.2 & 0.11 & 960 & $3.86 \cdot 10^{-3}$ & $8.44 \cdot 10^{-3}$ \\
11 & 0.10 & 1038 & $2.67 \cdot 10^{-3}$ & $7.65 \cdot 10^{-3}$ \\
\hline 3.7 & 0.14 & 985 & - & $13.70 \cdot 10^{-3 *}$ \\
\hline
\end{tabular}

*Exchange time was increased to $120 \mathrm{~h}$ instead of $24 \mathrm{~h}$

The highest copper load was obtained in samples with smaller average crystal sizes. This suggests an inhomogenous copper distribution is obtained during the exchange, which is related to the external surface of the crystals. As copper ions occupy part of the internal void volume they will, when located near the surface, block the pore system and thus affect the intrarcrystalline diffusion properties. This is reflected in the changes in micropore volume measured by nitrogen adsorption as shown in Table 4.2. After ion exchange the available pore volume is seen to decrease, but upon calcination at high temperature it returns to a number similar to the parent material without copper. The recovery of the micropore volume furthermore show that calcination does not lead to a collapse of the crystal structure, which was also verified by the preservation of 
the crystallinity as shown by the X-ray diffractograms in Figure 4.1.

Table 4.2: Micropore volume calculated using the t-plot method of SAPO-34 and $\mathrm{Cu}-\mathrm{SAPO}-34\left(1.2 \mathrm{wt}\right.$. \%) before and after calcination at $750{ }^{\circ} \mathrm{C}$

\begin{tabular}{ccc}
\hline Sample & treatment & $\begin{array}{c}\mathrm{V}_{\text {micro }} \\
\mathrm{cm}^{3} / \mathrm{g}\end{array}$ \\
\hline SAPO-34 & calcined $\left(500{ }^{\circ} \mathrm{C}\right)$ & 0.21 \\
$\mathrm{Cu}-\mathrm{SAPO}-34$ & after ion-exchange & 0.16 \\
$\mathrm{Cu}-\mathrm{SAPO}-34$ & calcined $\left(750^{\circ} \mathrm{C}\right)$ & 0.20 \\
\hline
\end{tabular}

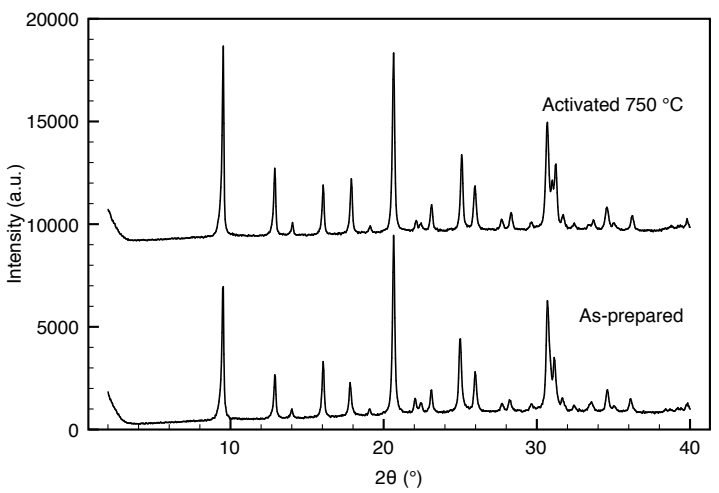

Figure 4.1: X-ray diffractograms of Cu-SAPO-34 (1.2 wt. \% Cu) before and after calcination at $750{ }^{\circ} \mathrm{C}$

Copper migration was followed by x-ray photoelectron spectra (XPS) and spectra were recorded after increased temperature treatments $\left(250-750{ }^{\circ} \mathrm{C}\right)$ on $\mathrm{Cu}$ SAPO-34 and on Cu-SSZ-13 for comparison. Results of the XPS characterization are shown in Figure 4.2. As XPS using an AlK $\alpha$ X-ray source gives an average sampling depth in the range of a few unit cells of the CHA structure it is possible to follow the concentration of copper in the subsurface region after activation at each temperature. 
From the XPS results shown in Figure 4.2 it is clear that upon heating $\mathrm{Cu}-$ SAPO-34 Cu migrates from the surface and the outer unit cells into the material, which is followed by the decrease in the $\mathrm{Cu} 2 \mathrm{p}_{3 / 2}$ peak. In comparison, no changes in surface concentration of $\mathrm{Cu}$ in $\mathrm{Cu}-\mathrm{SSZ}-13$ before and after activation at $750{ }^{\circ} \mathrm{C}$ were observed. This clearly confirms the hypothesis that copper is initially not homogeneously distributed in Cu-SAPO-34 and activation leads to migration of copper ions from the surface region.
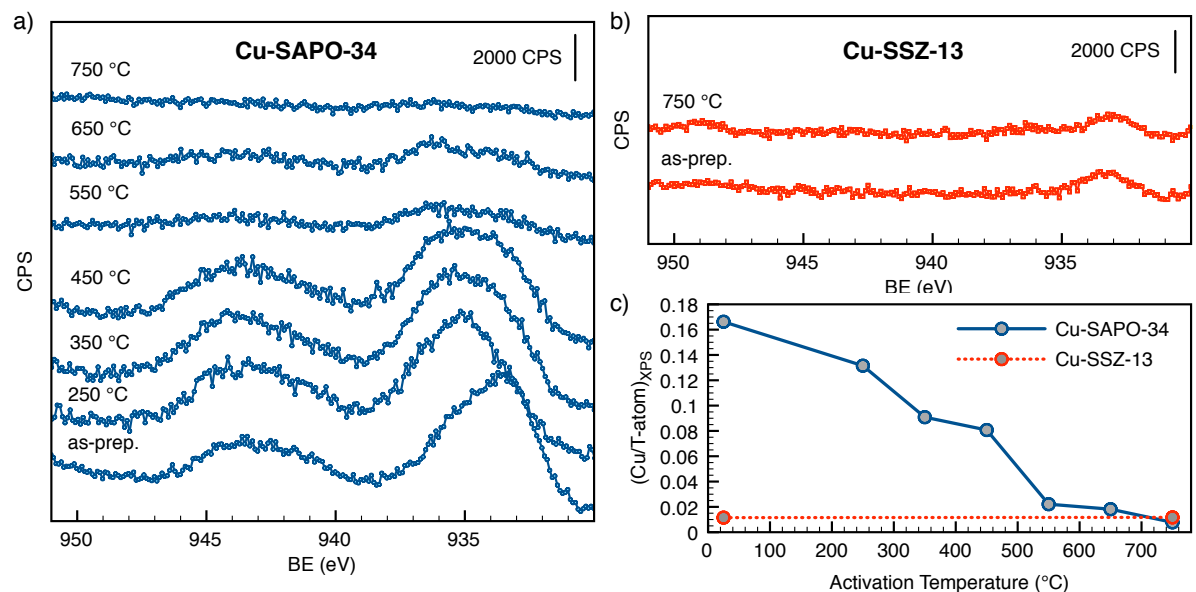

Figure 4.2: X-ray photoelectron spectra of the $\mathrm{Cu} 2 \mathrm{p}_{3 / 2}$ region of a) $\mathrm{Cu}$ SAPO-34 (1.2 wt.\%), b) Cu-SSZ-13 (2.4 wt.\%) before and after activation at various temperatures for $1 \mathrm{~h}$ and c) quantification of the $\mathrm{Cu} / \mathrm{T}$-atom ratio in the surface from XPS

It is also possible to comment further on the differences between copper species from the details of the XPS spectra. The $\mathrm{Cu} 2 \mathrm{p}_{3 / 2}$ binding energies (BE) observed in the XPS spectra measured on as-prepared $\mathrm{Cu}-\mathrm{SSZ}-13$ and $\mathrm{Cu}-\mathrm{SAPO}-$ 34 are initially similar and located at $933.3 \mathrm{eV}$. Although the two samples initially have similar BEs, Cu-SAPO-34 also has a small contribution in the $\mathrm{Cu}$ $\mathrm{L}_{3} \mathrm{VV}$ Auger spectra at kinetic energies (KE) at ca. $917 \mathrm{eV}$ (Figure 4.3), which has been ascribed to copper oxide at the surface of copper exchanged zeolites after reduction, [77] but this is consumed after activation above $250{ }^{\circ} \mathrm{C}$ as seen by the disappearance of the small shoulder at higher KEs. Adding to this; the satellite peak in the XPS spectra located around $943 \mathrm{eV}$ indicates that most 
of the $\mathrm{Cu}$ is present in oxidation state II and since $\mathrm{Cu}$ (II)oxide would show up at $917.9 \mathrm{eV}[78]$ in the Auger spectra, it is clear that even if present, copper oxide only constitutes a small fraction at this stage and is completely removed at higher temperatures.

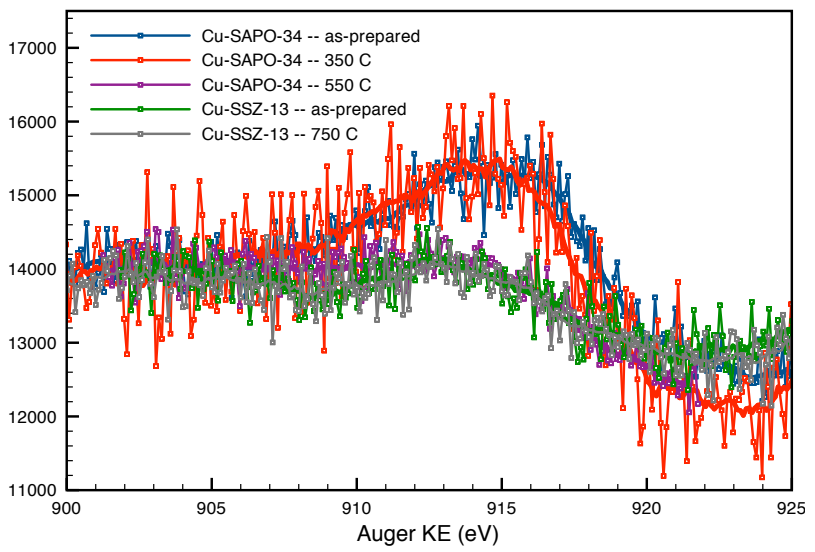

Figure 4.3: Auger spectra of Cu-SAPO-34 (1.2 wt.\% Cu) before and after activation at 350 and $550{ }^{\circ} \mathrm{C}$ as well as Cu-SSZ-13 (2.4 wt.\% Cu) before and after activation at $750{ }^{\circ} \mathrm{C}$

For all other treatments and irrespective of material the center of the $\mathrm{Cu} \mathrm{L}_{3} \mathrm{VV}$ Auger peaks are only observed below $915 \mathrm{eV}$, which is consistent with copper being located in ion exchange positions. After heating to $250{ }^{\circ} \mathrm{C}$ the largest contribution to the $\mathrm{Cu} 2 \mathrm{p}_{3 / 2} \mathrm{BE}$ in $\mathrm{Cu}-\mathrm{SAPO}-34$ is shifted to higher energies $(935.6 \mathrm{eV})$ and further heating causes peak broadening due the presence of at least two states of $\mathrm{Cu}$. Most likely these could arise due to the variations in exchange environments inside SAPO-34 i.e. isolated Si sites or edges of Si-islands. These can be monitored by ${ }^{29} \mathrm{Si}-\mathrm{MAS}-\mathrm{NMR}$. In this case NMR results confirm the presence of such environments in the parent SAPO-34 (see Chapter 5). In comparison the $\mathrm{Cu} 2 \mathrm{p}_{3 / 2}$ photo electron BE remains unaffected in $\mathrm{Cu}-\mathrm{SSZ}-13$ after heating to $750{ }^{\circ} \mathrm{C}$ indicating that no overall migration has taken place in this system after the heat treatment and that the copper only exists in one type of environment.

It should furthermore be added that the quantification of the $\mathrm{Cu} / \mathrm{T}$-atom ratio 
shown in Figure 4.2c indicate that migration of copper from the surface and sub-surface regions occurs in discrete temperature intervals. Again, this seem to confirm the hypothesis of various Si-environments. In particular it is to be expected that migration should be most pronounced when Si atoms are located in close proximity, which is further explored in Chapter 5. It should also be noted that only after activation at $750{ }^{\circ} \mathrm{C}$ does the $\mathrm{Cu} / \mathrm{T}$-atom ratio drop to that expected for a homogenous distribution of the copper ions.

The XPS results alone are not sufficient to describe how the copper distributes upon the activation and several scenarios may be envisioned. The copper migration was for this reason monitored by characteristic X-ray intensity maps of $\mathrm{Cu}-\mathrm{SAPO}-34$ before and after activation at $750{ }^{\circ} \mathrm{C}$. In all cases a copper rim was visible in the surface of the $\mathrm{Cu}-\mathrm{SAPO}-34$ in the as-prepared sample and a homogenously distribution of $\mathrm{Cu}$ in the activated sample observed (Figure 4.4a,b). The copper rim in as-prepared Cu-SAPO-34 (Figure 4.4a) indicates that $\mathrm{Cu}$ is indeed locally concentrated in the outer surface of the as-prepared SAPOmaterial, which correlate with the simultaneous increase in x-ray intensity from framework elements as seen in the linescan (right panel, Figure 4.4). After activation the normalized intensity of the characteristic X-Rays from framework T-atoms and $\mathrm{Cu}$ measured across the crystal show no individual variation in concentration across the crystal and confirm the homogenous distribution of all the elements.
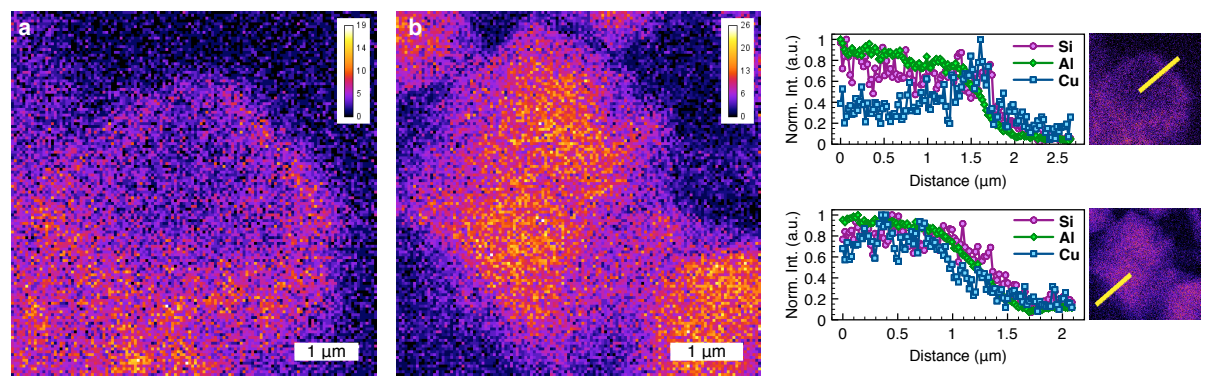

Figure 4.4: Pseudocolor representation of the spacial difference in K $\alpha$ X-Ray intensity for $\mathrm{Cu}$ in a) as-prepared Cu-SAPO-34 and b) Cu-SAPO-34 activated at $750{ }^{\circ} \mathrm{C}$ for $1 \mathrm{~h}$. Right: comparison of normalized X-ray intensities for $\mathrm{Si}$ (purple), $\mathrm{Al}$ (green) and $\mathrm{Cu}$ (blue). Data were extracted from the maps at the areas indicated by the yellow lines and averaged over 10 pixels, corresponding to the line thickness 
To compare the influence of copper redistribution on catalytic performance turnover-frequencies have been used. Based on the measured $\mathrm{NO}_{\mathrm{x}}$ conversion (always $<25 \%$ ) in the $\mathrm{NH}_{3}$-SCR reaction pseudo-first order kinetics were applied and turn-over frequencies (TOFs) calculated before and after thermal treatments according to equation 4.1 and 4.2 , where $k_{\mathrm{SCR}}$ is the rate constant, $F_{\text {total }}$ is the total molar flow, $m_{\text {cat }}$ the mass of catalyst, $m_{\mathrm{Cu}}$ the mass of $\mathrm{Cu}$ in the catalyst, $P$ the total pressure, $X_{\mathrm{NOx}}$ the fractional conversion of $\mathrm{NO}_{\mathrm{x}}$ and $n_{\mathrm{Cu} \text {,cat }}$ the moles of $\mathrm{Cu}$ in the catalyst.

$$
\begin{aligned}
k_{\mathrm{SCR}} & =-\frac{F_{\mathrm{total}, 0}}{m_{\mathrm{cat}} \cdot P} \ln \left(1-X_{\mathrm{NOx}}\right) \\
T O F & =k_{\mathrm{SCR}} \cdot P \cdot \frac{m_{\mathrm{cat}} \cdot M_{w, \mathrm{Cu}}}{m_{\mathrm{Cu}}}=-\frac{F_{\mathrm{total}, 0}}{n_{\mathrm{Cu}, \mathrm{cat}}} \ln \left(1-X_{\mathrm{NOx}}\right)
\end{aligned}
$$

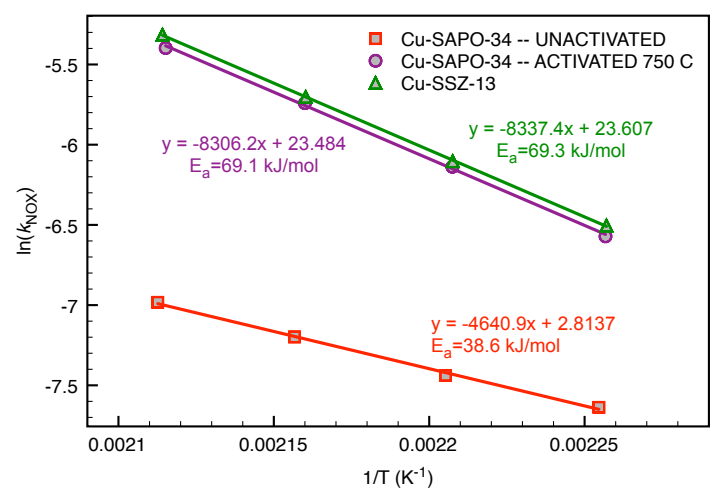

Figure 4.5: Arrhenius plots based on pseudo-first order rate constants for $\mathrm{Cu}-\mathrm{SAPO}-34$ (1.2 wt.\%) before and after activation for $1 \mathrm{~h}$ at $750{ }^{\circ} \mathrm{C}$ in $10 \%$ $\mathrm{O}_{2}$ as well as Cu-SSZ-13 (2.4 wt.\%). Catalytic test conditions were Catalytic test conditions were: $500 \mathrm{ppm} \mathrm{NO}, 530 \mathrm{ppm} \mathrm{NH}_{3}, 10 \% \mathrm{O}_{2}, 5 \% \mathrm{H}_{2} \mathrm{O}$, balance $\mathrm{N}_{2}$ to a total flow of $300 \mathrm{NmL} / \mathrm{min}$ using in $10 \mathrm{mg}$ catalyst

In Figure 4.5 an Arrhenius plot for Cu-SAPO-34 and Cu-SSZ-13 is shown before and after activation at $750{ }^{\circ} \mathrm{C}$. Cu-SAPO-34 have an activation energy of 38.6 $\mathrm{kJ} / \mathrm{mol}$ before thermal treatment in the $\mathrm{NH}_{3}-\mathrm{SCR}$ reaction. After activation at $750{ }^{\circ} \mathrm{C}$ it increases to $69.1 \mathrm{~kJ} / \mathrm{mol}$. In comparison $\mathrm{Cu}-\mathrm{SSZ}-13$ show an activation energy of $69.3 \mathrm{~kJ} / \mathrm{mol}$ irrespective of the treatment. As the activation 
energy for diffusion is smaller than for chemical reactions in general, the increase in apparent activation energy for $\mathrm{Cu}-\mathrm{SAPO}-34$ indicates removal of a diffusion barrier. This is in good agreement with the measurements of the available pore volume (see Table 4.2). Additionally, the similarity in activation energy between activated $\mathrm{Cu}-\mathrm{SAPO}-34$ and $\mathrm{Cu}-\mathrm{SSZ}-13$ further confirms that the SCR reaction proceeds via a similar mechanism over the two materials.

The impact of copper redistribution on $\mathrm{NH}_{3}$-SCR activity after thermal treatments between 250 and $850{ }^{\circ} \mathrm{C}$ is shown in Figure 4.6a. For comparison $\mathrm{Cu}-$ SSZ-13 with similar copper loading as the Cu-SAPO-34 was also prepared and exposed to the same treatment.

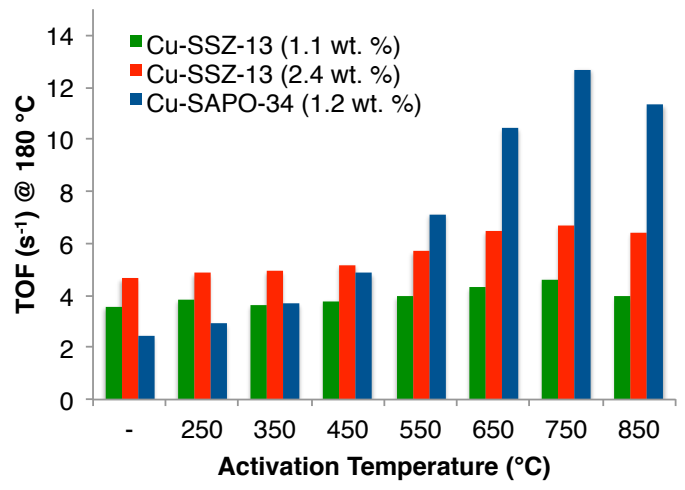

Figure 4.6: Catalytic TOFs $\left(\mathrm{mol}_{\mathrm{gas}} \cdot \mathrm{mol}_{\mathrm{Cu}}^{-1} \cdot \mathrm{s}^{-1}\right)$ after activation at increasing temperatures for Cu-SAPO-34 (1.2 wt.\%; $3.7 \mu \mathrm{m}$ crystal size) and Cu-SSZ-13 (1.1 and 2.4 wt.\%). Catalytic conditions were similar as to those reported in Figure 4.5 where $10 \mathrm{mg}$ catalyst was used

Figure 4.6 clearly illustrates that the catalytic activity is increased considerably upon the thermal treatment. The TOFs for Cu-SAPO-34 increases several times and reaches a maximum after activation at $750{ }^{\circ} \mathrm{C}$. Thus, in order to exploit the full potential of $\mathrm{Cu}-\mathrm{SAPO}-34$ it requires an activation at temperatures as high as $750{ }^{\circ} \mathrm{C}$. Activation at higher temperatures does not further improve the catalytic performance in this case. In comparison, the aluminosilicate $\mathrm{Cu}-\mathrm{SSZ}-13$ was almost unaffected by the same temperature treatments except for a small increase above $550{ }^{\circ} \mathrm{C}$. 
In terms of $\mathrm{NO}_{\mathrm{x}}$ conversion per mass of catalyst Cu-SAPO-34 with 1.2 wt. \% of $\mathrm{Cu}$ reaches the same conversion as the $\mathrm{Cu}-\mathrm{SSZ}-13$ with 2.4 wt. \% Cu. This is seen by the double TOF obtained for Cu-SAPO-34 after activation. Such similarities could indicate that TOF numbers become higher for lower copper loads, which is not the case, as illustrated by the low TOF for the Cu-SSZ-13 with 1.1 wt. $\% \mathrm{Cu}$. Oppositely, the Cu-SSZ-13 with low copper content appear to show a lower TOF. To further explore if this is also the case for $\mathrm{Cu}-\mathrm{SAPO}-34$, a series of $\mathrm{Cu}$-SAPO-34 with different copper amounts were prepared, activated at $750{ }^{\circ} \mathrm{C}$ and tested in the $\mathrm{NH}_{3}$-SCR reaction. Figure 4.7 show the calculated rate constants and TOFs at 170,180 and $190{ }^{\circ} \mathrm{C}$ for $\mathrm{Cu}-\mathrm{SAPO}-34$ materials with different copper loads in the $\mathrm{NH}_{3}-\mathrm{SCR}$ reaction. As can be seen, there is a slight increase in rate constants (per mass of catalyst) with increasing copper loads. Additionally, TOFs also increase for higher copper loads.
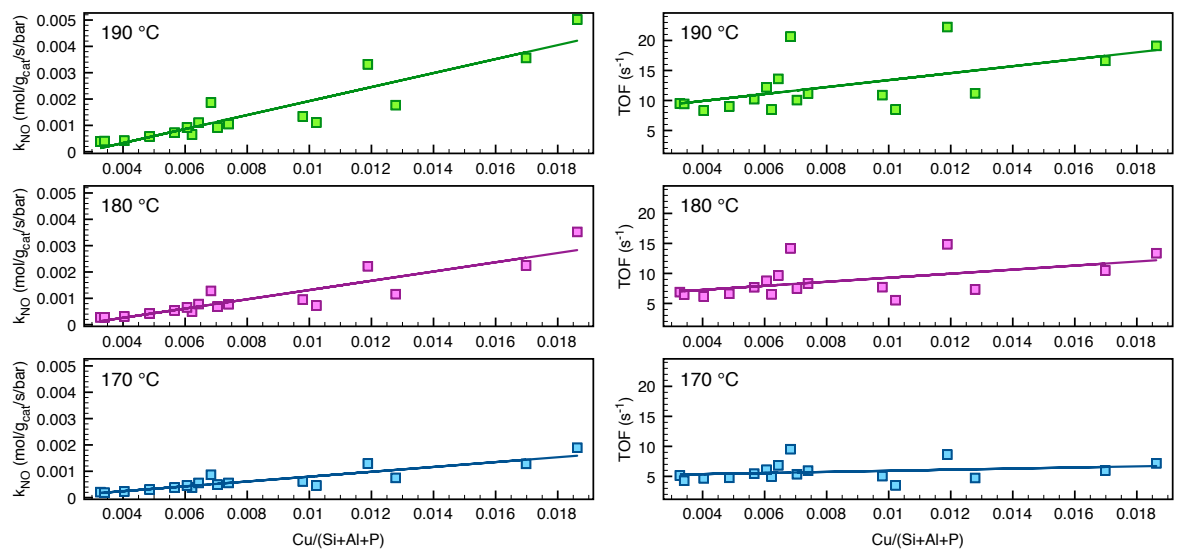

Figure 4.7: Activity of various $\mathrm{Cu}-\mathrm{SAPO}-34$ catalysts prepared by aqueous ion exchange. In a) pseudo-first order rate constants and b) TOFs calculated based on $\mathrm{NO}_{\mathrm{x}}$ conversion in the $\mathrm{NH}_{3}$-SCR reaction under steady state conversion at 170,180 and $190{ }^{\circ} \mathrm{C}$. Conditions were: $500 \mathrm{ppm} \mathrm{NO}, 530 \mathrm{ppm} \mathrm{NH}$, $10 \% \mathrm{O}_{2}, 5 \% \mathrm{H}_{2} \mathrm{O}$, balance $\mathrm{N} 2$ to a total flow of $300 \mathrm{NmL} / \mathrm{min}$ and using 20 mg catalyst after activation for $1 \mathrm{~h}$ at $750{ }^{\circ} \mathrm{C}$ in $10 \% \mathrm{O}_{2}$

In Figure 4.7 small fluctuations around the trend line is seen. As various parent SAPO-34 materials were used here, the fluctuations most likely occur due to the 
differences in crystal size between the various materials. Especially the small increase in TOFs at higher temperatures with copper load can be explained by the fact that high copper loads could only be obtained for small to intermediate crystal sizes. Moreover, the difference after activation between small crystals and large crystals is based on a tradeoff between stability of large crystals, and less diffusion limitations in small crystals. This is illustrated in Figure 4.8 where the influence on activation on TOFs for $\mathrm{Cu}-\mathrm{SAPO}-34$ catalysts with different crystal sizes, but similar copper loads are shown. Figure 4.8 also give another explanation for the small fluctuations in $k_{\mathrm{NOx}}$ and TOFs in Figure 4.7 as the optimal activation temperature is different for the various $\mathrm{Cu}-\mathrm{SAPO}-34$ and thus all catalysts might not have been activated sufficiently in Figure 4.7.

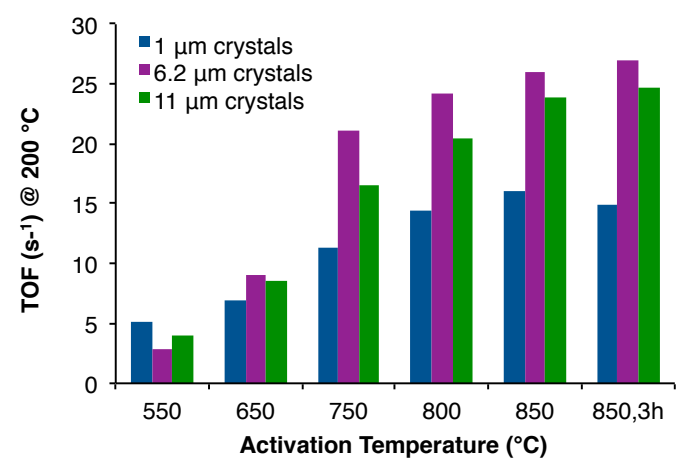

Figure 4.8: Catalytic TOFs $\left(\mathrm{mol}_{\mathrm{gas}} \cdot \mathrm{mol}_{\mathrm{Cu}}^{-1} \cdot \mathrm{s}^{-1}\right)$ after activation at increasing temperatures for Cu-SAPO-34 (0.66 \pm 0.03 wt.\%) with different crystal sizes. Catalytic conditions were similar as to those reported in Figure 4.5 where $40 \mathrm{mg}$ catalyst was used

\subsection{Summary and Conclusions}

In this chapter it was shown that introduction of copper by aqueous ion exchange into SAPO-34 is non-trivial. Maximum obtainable copper loads depend on crystal sizes and not on the number of acid sites or silicon amounts in SAPO34. As the amount of copper introduced under similar ion exchange conditions 
was higher for samples with small average crystal sizes it was suggested that exchanged copper species become located in the sub-surface of SAPO-34 crystals during exchange and make the inner volume of the crystals less accessible.

It was further demonstrated how copper in Cu-SAPO-34 can be redistributed upon thermal treatments. The migration of $\mathrm{Cu}$ from the surface region of $\mathrm{Cu}-$ SAPO-34 was monitored and confirmed by XPS and Auger spectroscopy after activation at temperatures between 250 and $750{ }^{\circ} \mathrm{C}$. In combination those methods showed that a small fraction of the copper might be present as copper oxide at the surface of $\mathrm{Cu}$-SAPO-34 initially, but upon heating it moves into ion exchange positions and further into the material. Additionally, the XPS binding energies of copper species in SAPO-34 also indicated the presence of different silicon environments for the copper species. Further quantification of the surface copper amounts showed that copper migrates in different temperature intervals, which can be related to the distance between exchange sites i.e. distance between framework Si-atoms. In comparison Cu-SSZ-13 showed a homogeneous distribution of $\mathrm{Cu}$ and no changes in surface concentration or copper speciation after treatments up to $750{ }^{\circ} \mathrm{C}$. To show that a homogenous distribution of copper is obtained in $\mathrm{Cu}-\mathrm{SAPO}-34$ after activation characteristic x-ray intensity maps were recorded before and after activation. These confirmed the initial location of copper in the surface region of SAPO-34 and that it becomes homogeneously distributed upon the activation treatment.

After the thermal activation several fold increase in catalytic turn-over-frequencies was experienced for $\mathrm{Cu}-\mathrm{SAPO}-34$ surpassing that of $\mathrm{Cu}-\mathrm{SSZ}-13$. The increase in catalytic activity upon copper redistribution was shown to be related to the removal of a diffusion barrier. This was confirmed by the increase in apparent activation energy from $38.6 \mathrm{~kJ} / \mathrm{mol}$ to $69.1 \mathrm{~kJ} / \mathrm{mol}$ and a recovery of the initial micropore volume after thermal activation. Last, it was shown that the high activity of $\mathrm{Cu}-\mathrm{SAPO}-34$ compared to $\mathrm{Cu}-\mathrm{SSZ}-13$ is not a consequence of the differences in copper load between the two catalysts by comparison of different copper loads on Cu-SAPO-34 as well as on Cu-SSZ-13.

The ability of Cu-SAPO-34 to give even higher catalytic TOFs makes Cu-SAPO34 a highly relevant catalyst for industrial applications. 
CHAPTER 5

\section{Influence of the atmosphere on Cu-SAPO-34 activation and its performance in the $\mathrm{NH}_{3}-\mathrm{SCR}$ reaction}

\subsection{Introduction}

Several studies have been devoted to cation migration in zeolites from one crystallographic site to another. Zema et al. for instance studied natural chabazite and documented cation migration $\left(\mathrm{Ca}^{2+}\right.$ and $\left.\mathrm{Na}^{+}\right)$from preferential positions inside the large cage in the CHA structure towards coordination in the doublesix-member ring and in the eight member ring window once the zeolite was dehydrated at elevated temperatures.[79] Most other studies have been concerned with cation migration with and without the aid of adsorbates in faujasites. [8084] Common for these studies is that migration is studied in Al-rich zeolites, which leads to relatively facile migration as the $\mathrm{Al}$ atoms are in close proximity and barriers around $0.60 \mathrm{eV}$ were found in the case of sodium migration in FAU.[81]

In Chapter 4 it was shown that copper ions migrate from the sub-surface region of $\mathrm{Cu}-\mathrm{SAPO}-34$ crystals towards the interior, once they were heated to high temperatures e.g. up to $750{ }^{\circ} \mathrm{C}$. Since different adsorbates may change the 
binding energy of extra-framework species in SAPO-34, this chapter explores how different atmospheres may facilitate the migration copper ions to yield a more active catalyst. Industrial operating conditions relevant for this type of catalyst will typically be between 180 and $500{ }^{\circ} \mathrm{C}$. Under these conditions it was already shown in Chapter 4 that a large fraction of copper ions are able to migrate. For this reason the present chapter will focus on the fraction of copper species that require high temperatures to migrate.

The fraction of copper ions that migrate at high temperatures $\left(>500-600{ }^{\circ} \mathrm{C}\right)$ is in this chapter modeled by considering migration between Si-sites in Cu-SAPO34 separated by more than one $\mathrm{Al}$ atom. The amount of such sites is estimated based on a binomial distribution and experimental inputs from ICP as well as ${ }^{29}$ Si-MAS-NMR. Afterwards Gibbs free energy phase diagrams based on DFT calculations are used to describe the stability of various copper species inside the SAPO-34 matrix. Based on the most stable and relevant species at higher temperatures the migration of $\mathrm{Cu}$-species and protons is investigated using the nudged elastic band (NEB) and climbing image method. Finally, various atmosphere compositions at $750{ }^{\circ} \mathrm{C}$ are applied and the catalytic activity in the $\mathrm{NH}_{3}$-SCR is measured experimentally to verify the theoretical predictions.

\subsection{Experimental}

\subsubsection{Materials}

The Cu-SAPO-34 used for this investigation is similar to that reported in Chapter 4 . In short, the preparation of the material was performed by first calcining the parent SAPO-34 obtained from a commercial supplier at $580{ }^{\circ} \mathrm{C}$ for $3 \mathrm{~h}$. Then it was ion exchanged in an aqueous solution of $\mathrm{Cu}$ (II)acetate monohydrate (Sigma-Aldrich $\geq 99.0 \%$ ) for $120 \mathrm{~h}$ at room temperature at a solid to liquid ratio of $250 \mathrm{~mL} / \mathrm{g}$. Afterwards it was washed with deminieralized water and dried at $100{ }^{\circ} \mathrm{C}$ for a minimum of $12 \mathrm{~h}$ before use.

\subsubsection{Characterization and catalytic testing}

${ }^{29}$ Si-MAS-NMR spectra were recorded at room temperature on a Bruker AV 400 spectrometer. Spectra were recorded with a spinning rate of $5 \mathrm{kHz}$ at 79.459 $\mathrm{MHz}$ with a $55^{\circ}$ pulse length of $3.5 \mu \mathrm{s}$ and repetition time of $180 \mathrm{~s}$. Pretreatments and the catalytic reactions were carried out in a fixed bed quartz reactor 
(i.d. $2 \mathrm{~mm}$ ). All pretreatments involved heating the sample at $10{ }^{\circ} \mathrm{C} / \mathrm{min}$ to $750{ }^{\circ} \mathrm{C}$ for $3 \mathrm{~h}$ in an atmosphere of $\mathrm{N}_{2}, 15 \% \mathrm{O}_{2}, 15 \% \mathrm{H}_{2} \mathrm{O}$ or $15 \% \mathrm{O}_{2}$ and $15 \% \mathrm{H}_{2} \mathrm{O}$ at a total flow of $100 \mathrm{NmL} / \mathrm{min}$ (balanced by $\mathrm{N}_{2}$ ). Afterwards the catalyst was cooled to reaction temperatures in $10 \% \mathrm{O}_{2}$ (except when only $\mathrm{N}_{2}$ was wanted) and steady state conversions were measured in the temperature interval $170-500{ }^{\circ} \mathrm{C}$. In all cases $10 \mathrm{mg}$ catalyst (150-300 $\mu \mathrm{m}$ sieve fraction) was used and the performance measured using $500 \mathrm{ppm} \mathrm{NO}, 530 \mathrm{ppm} \mathrm{NH} 3,10$ $\% \mathrm{O}_{2}$, and $5 \% \mathrm{H}_{2} \mathrm{O}$, balanced with $\mathrm{N}_{2}$ to a total flow rate of $300 \mathrm{NmL} / \mathrm{min}$. The outlet gas was analyzed by a Gasmet CX4000 FTIR analyzer.

\subsubsection{DFT calculations}

DFT calculations were performed using a real space grid-based projector-augmented wave method (GPAW) [85, 86] together with the atomic simulation environment (ASE) interface.[87]. All calculations were performed using periodic boundary conditions and the RPBE functional. The unit cell was optimized using a 0.15 $\AA$ grid spacing (with constant number of grid points) and all other calculations performed using $0.20 \AA$ in the optimized cell. Furthermore only the $\Gamma$ point of the Brillouin zone was sampled using $0.1 \mathrm{eV}$ Fermi smearing. All computational parameters were checked and found sufficient from all convergence tests. Due to the presence of copper, spin polarization was applied, but was only found necessary in the case of $[\mathrm{CuOH}]$ species.

The unit cell of SAPO-34 was created from the R-3m space group given by the IZA Structure database for CHA,[9] where Si atoms were replaced by alternating $\mathrm{Al}$ and $\mathrm{P}$ atoms. First this unit cell was optimized and afterwards two Si atoms were isomorphously substituted with $\mathrm{P}$ atoms together with one $\mathrm{H}$ and one $\mathrm{Cu}$ atom as shown in Figure 5.3 and the unit cell optimized again. Determination of the cell parameters involved initially minimizing the energy depending on the unit cell volume and afterwards depending on the two unit cell vectors of the hexagonal cell. In all optimizations a force threshold of $0.03 \mathrm{eV} / \AA$ was used and positions of all atoms in the unit cell was allowed to relax. The lattice constants obtained from the SAPO-34 unit cell containing $2 \mathrm{Si}, 1 \mathrm{H}$ and $1 \mathrm{Cu}$ were used in all further calculations.

Various extra lattice species where then introduced and all intermediates found using a force threshold of $0.03 \mathrm{eV} / \AA$ on fully relaxed structures. The minimum energy paths for migration of the various copper species and protons were found using the nudged elastic band method[88] in combination with the climbing image method[89] to locate the transition states, and in this case applying a force 
threshold of $0.05 \mathrm{eV} / \AA$.

DFT results were also used to construct $a b$ initio phase diagram to estimate the stability of the various copper species. Here, it should be noted that an approach similar to the one applied by Nørskov et al. was used,[90] where the experimental reaction $\Delta H_{\mathrm{H}_{2} \mathrm{O}}$ value was used to correct the $\mathrm{O}_{2}$ total energy. In this way the difficulties of obtaining correct numbers from DFT calculations for $\mathrm{O}_{2}$ was avoided.[91]

\subsection{Results and Discussion}

\subsubsection{Determination of the amount of Si without other Si as next-nearest neighbors}

In SAPO materials Si substitute $\mathrm{P}$, according to what is usually referred to as the "SM2" mechanism, [92] which is analogous to the substitution of Si with $\mathrm{Al}$ in zeolites, where a negative charge is assigned to the oxygens of the framework around this location. Coordination to these oxygens is also where the copper ions are expected to be located. In more silicon rich SAPO materials Si may start to substitute pairs of $\mathrm{P}$ and Al atoms, cf. the "SM3" substitution mechanism.[92] If this occurs more extensively, silicon islands can form, where negative charge is only assigned to the edges of these domains. [93] Moreover, depending on the Si amount[94] as well as synthesis[95] and post synthesis treatments[96], the distance between Si atoms and Si-island formation may vary.

In order to investigate the migration of copper ions from one $\mathrm{Si}$ microenvironment to another, the $\mathrm{Si}-\mathrm{Si}$ distances should be considered. If $\mathrm{Si}$ islands are not formed the shortest distance would correspond to Si atoms only separated by one $\mathrm{Al}$ atom (next nearest neighboring Si atoms (NNN)). The second shortest $\mathrm{Si}-\mathrm{Si}$ distance is where the two $\mathrm{Si}$ atoms are separated by one $\mathrm{P}$ and two $\mathrm{Al}$ tetrahedra. The two shortest coordination sequences are for clarity shown in Figure 5.1. For Si with another Si-NNN the migration of a cation from the first to the second Si microenvironment is not going to involve large energy barriers because large charge separations will not occur. Thus we expect barriers close to those found for monovalent cation migration in Al-rich FAU $(<0.6 \mathrm{eV})$.[81] Migration of cations, and in this case copper cation species, in an environment without any Si-NNN is less favorable because of the larger charge-separation associated with longer distance between $\mathrm{Si}$ atoms as compared to $\mathrm{Si}$ with $\mathrm{Si}$ - 
NNN. When the Si-content is decreased in a SAPO-material the average Si-Si distance is expected to increase. Since the SAPO-34 materials used in this study contain relatively large amounts of $\mathrm{Si}$, the most dominant $\mathrm{Si}$-Si distances should be those shown in Figure 5.1, and these two sequences are expected to dominate if Si-island formation is neglected.

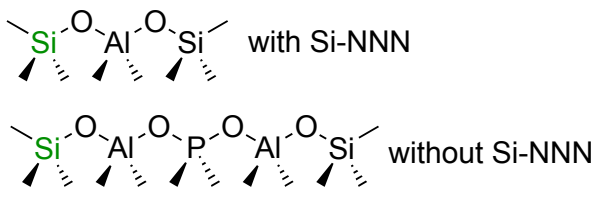

Figure 5.1: Configuration and illustrative distance between a $\mathrm{Si}$ with a NNN (top) and without a NNN (bottom) assuming that $\mathrm{Si}$ only replace $\mathrm{P}$ and no Si-islands are formed

For zeolites the probability of finding an $\mathrm{Al}$ atom in zeolite frameworks with $n$ next nearest neighbors (NNN) is according to Sonnemans et al. approximated well by a binomial distribution.[97] This assumption leads to a simple analytical solution to the fraction of Al with NNNs. In a later study Rice et al. tested the analytical solution against other more sophisticated methods and found that the analytical solution is adequate enough to describe the fraction of NNN in classical zeolite frameworks compared to other more sophisticated theoretical methods.[98] Although it is known that $\mathrm{Al}$ is not randomly distributed, but may be controlled by synthesis conditions, templates and Al-sources,[99] it will serve sufficiently to describe the phenomenon in this study.

If a similar binomial distribution approach is applied to SAPO-materials as it was applied by Sonnemans on zeolites, [97] the fraction of Si without Si-NNN may be estimated in SAPO-34. Assuming that Si only replaces $\mathrm{P}$, the probability of finding $n \mathrm{Si}$ atoms separated by only one $\left[\mathrm{AlO}_{4}\right]$ unit is given by equation 5.1 where $N$ is the average number of T-atoms in NNN positions

$$
P_{n}=\frac{N !}{n ! \cdot(N-n) !} \cdot\left(\frac{\mathrm{Si}}{\mathrm{Si}+\mathrm{P}}\right)^{n} \cdot\left[1-\left(\frac{\mathrm{Si}}{\mathrm{Si}+\mathrm{P}}\right)\right]^{N-n}
$$




\section{Estimation for $\mathrm{Si}_{\text {isolated }} / \mathrm{P}$ ratio}

The input needed for equation 5.1 is the effective $\mathrm{Si} /(\mathrm{Si}+\mathrm{P})$ ratio. A rough estimate for this ratio may be obtained by neglecting the Si located in Si-islands, or in other words silicon with silicon neighbors in the experimentally used SAPO34 for this study. ${ }^{29} \mathrm{Si}-\mathrm{MAS}-\mathrm{NMR}$ can be used for this purpose as the chemical shift of $\mathrm{Si}$ is sensitive to the number of $\mathrm{Si}$ neighbors.

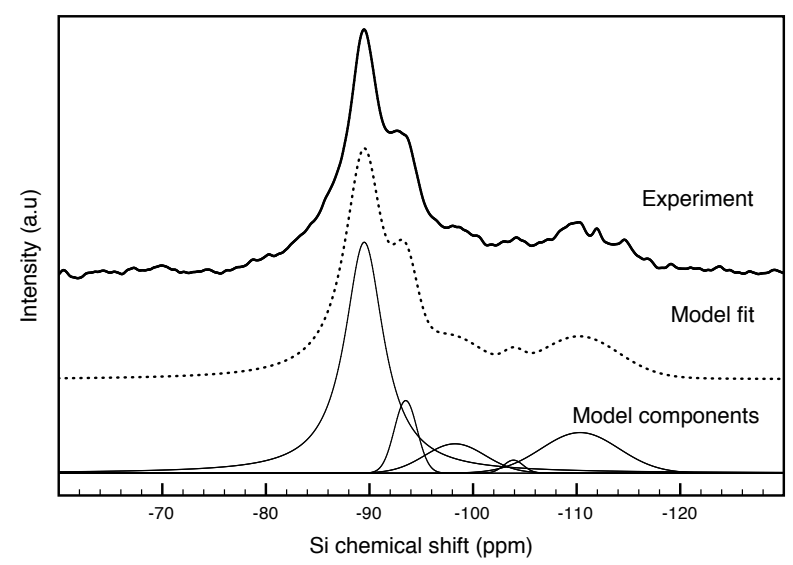

Figure 5.2: ${ }^{29} \mathrm{Si}-\mathrm{MAS}-\mathrm{NMR}$ and deconvolution into the components of parent SAPO-34. Resonance positions and integral percentages are given in Table 5.1

From the single pulse ${ }^{29} \mathrm{Si}-\mathrm{MAS}-\mathrm{NMR}$ spectrum shown in Figure 5.2 five different bands are observed. The larges contribution at $-110.3 \mathrm{ppm}$ corresponds to $\mathrm{Si}$ with four $\mathrm{Al}$ atoms in its proximity (isolated $\mathrm{Si}$ ) and the others to an increasing amount of Si-O-Si bonding as given in Table 5.1. [94, 100, 101] Quantification of the individual components were carried out by fitting Gaussian-Lorrentzian distributions (see lower parts of Figure 5.2). The results clearly indicate that a considerable fraction of the $\mathrm{Si}$ is located in Si islands and that only about two thirds of the $\mathrm{Si}$ is located as isolated Si framework atoms. 
Table 5.1: Resonance positions obtained from ${ }^{29} \mathrm{Si}-\mathrm{MAS}-\mathrm{NMR}$ and associated local structures on the parent SAPO-34 (5.63 wt.\% Si and 16.6 wt.\% P) together with the percentage of each contribution

\begin{tabular}{lcc}
\hline Resonance position $(\mathrm{ppm})$ & Local structure & \% integral \\
\hline-110.3 & $\mathrm{Si}(0 \mathrm{Al})$ & 15.4 \\
-103.9 & $\mathrm{Si}(1 \mathrm{Al})$ & 1.2 \\
-98.3 & $\mathrm{Si}(2 \mathrm{Al})$ & 8.6 \\
-93.5 & $\mathrm{Si}(3 \mathrm{Al})$ & 8.1 \\
-89.5 & $\mathrm{Si}(4 \mathrm{Al})$ & 66.6 \\
\hline
\end{tabular}

ICP-OES chemical analysis reveal that the parent SAPO-34 has a molar composition of $\mathrm{Si}_{0.28} \mathrm{Al}_{0.96} \mathrm{P}_{0.76} \mathrm{O}_{4}$, which indicate that $\mathrm{Si}$ has predominantly replaced $\mathrm{P}$, but that some Si island formation has also taken place. This composition gives the upper limit for the estimation of Si without any NNN. A more realistic result is obtained by combination with the NMR results. This forms the lower limit of the $\mathrm{Si} /(\mathrm{Si}+\mathrm{P})$ ratio.

In Table 5.2 is given the results from the estimation of Si without any Si-NNN based on equation 5.1 and the input from ICP and in combination with ${ }^{29} \mathrm{Si}-$ MAS-NMR. As can be seen a considerable fraction of the Si is located without any Si-NNN.

Table 5.2: Fraction of Si in the SAPO-34 without any Si-NNN based based on different effective $\mathrm{Si} /(\mathrm{Si}+\mathrm{P})$ ratios based on ICP and the combination with ${ }^{29} \mathrm{Si}-\mathrm{MAS}-\mathrm{NMR} . \mathrm{F}_{0}$ was calculated based on equation 5.1

\begin{tabular}{lcc}
\hline Method & $(\mathrm{Si} / \mathrm{P})_{\text {input }}$ & $\mathrm{F}_{0}$ (fraction of no Si-NNN) \\
\hline ICP & 0.27 & 0.08 \\
${ }^{29}$ Si-MAS-NMR & 0.20 & 0.17 \\
\hline
\end{tabular}

\subsubsection{Migration studies in SAPO-34 by DFT calculations}

To study the migration of various copper species in SAPO-34 DFT calculations were used. The optimized unit cell used for the DFT calculations containing copper is shown in Figure 5.3. Lattice constants found for the optimized cell are $\mathrm{a}=\mathrm{b}=14.107 \AA$ and $\mathrm{c}=15.335 \AA$, which is in reasonable agreement with experimentally measured values of $\mathrm{a}=\mathrm{b}=13.707 \AA$ and $\mathrm{c}=14.849 \AA$. Based 
on the hypothesis that the difficult migration occur in microenvironments where Si does not have any Si-NNN, the unit cell was constructed with two Si atoms, each located in the double six-member rings, and separated by one $\mathrm{P}$ and two $\mathrm{Al}$ atoms. For copper without any ligands we also find the most stable configuration to be in the plane of the six-member ring, which is in good agreement with diffraction data[33] and other theoretical DFT calculations of the $\mathrm{Cu}-\mathrm{CHA}$ system.[49]

The most stable configurations found for the bare $\mathrm{Cu}$ ion in the SAPO-34 system as well as with $\mathrm{OH}$ and $\mathrm{H}_{2} \mathrm{O}$ ligands are shown in Figure 5.4 and is named $[\mathrm{Cu}]-\mathrm{Z},[\mathrm{CuOH}]-\mathrm{Z}$ and $\left[\mathrm{Cu}\left(\mathrm{OH}_{2}\right)\right]$ respectively. Interestingly, upon adsorption of various ligands the $\mathrm{Cu}$-species are lifted up from the plane of the 6 -MR, but in all cases it remains coordinated to one or two of the oxygen atoms around the $\mathrm{Si}$ center. In the case of $[\mathrm{CuOH}-\mathrm{Z}]$ and $\left[\mathrm{Cu}\left(\mathrm{OH}_{2}\right)\right]-\mathrm{Z}$ several configurations were found separated by less than $0.1 \mathrm{eV}$, which indicates that several configurations of $\mathrm{Cu}$ may be present. Further adsorption of $\mathrm{H}_{2} \mathrm{O}$ in the $[\mathrm{CuOH}]-\mathrm{Z}$ system moves the most stable configuration away from the plane of the 6 -MR. Altogether these results explain why dehydration is needed to observe distinguished framework coordination by XAFS techniques, and why copper species in hydrated zeolites leads to isotropic EPR signals.

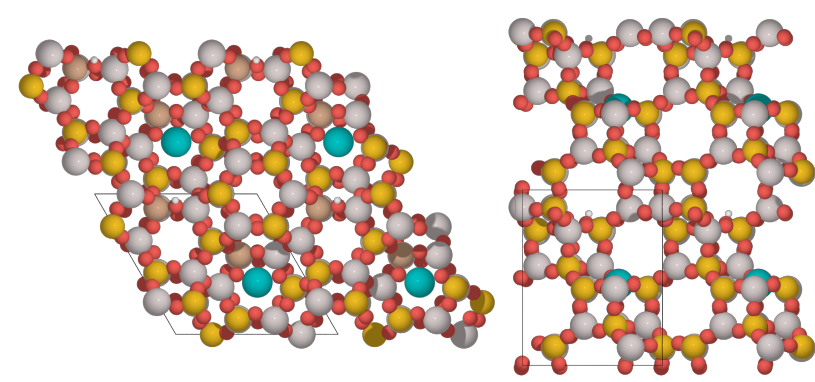

Figure 5.3: Optimized unit cell of $1 \mathrm{H} 1 \mathrm{Cu}-\mathrm{SAPO}-34$ system along the [001] direction to the left and along the [100] to the right; the unit cell is shown in black and atoms colors are: $\mathrm{Al}$ (grey), $\mathrm{P}$ (yellow), Si (sand), $\mathrm{O}$ (red) and $\mathrm{Cu}$ (turquoise). Each unit cell contains two $\mathrm{Si}$ atoms one $\mathrm{H}$ and one $\mathrm{Cu}$. Unit cell volume $=2642.81 \AA^{3}$ and $\mathrm{a}=\mathrm{b}=14.107 \AA$ and $\mathrm{c}=15.335 \AA$ 


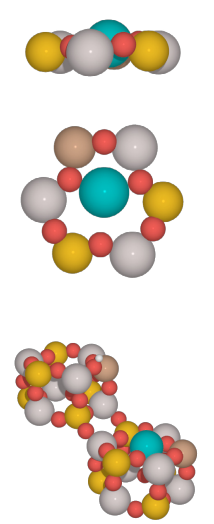

$[\mathrm{Cu}]-\mathbf{Z}$
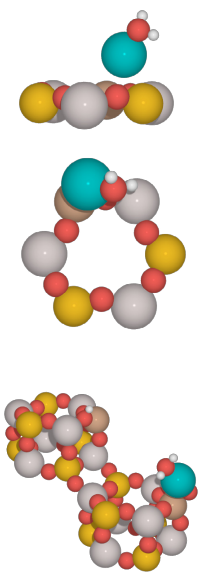

$\left[\mathrm{Cu}\left(\mathrm{H}_{2} \mathrm{O}\right)\right]-\mathrm{Z}$
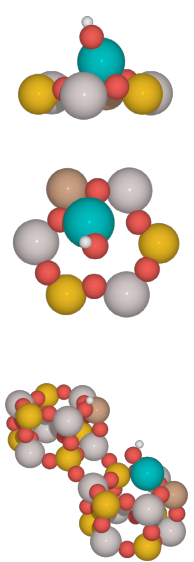

$[\mathrm{Cu}(\mathrm{OH})]-\mathrm{Z}$

Figure 5.4: $\mathrm{Cu}, \mathrm{Cu}\left(\mathrm{H}_{2} \mathrm{O}\right)$ in two configurations and $\mathrm{Cu}(\mathrm{OH})$ species in their initial location in the $\mathrm{d} 6 \mathrm{MR}$ containing one Si. Top panel: side view of the plane of the upper $6 \mathrm{MR}$; middle panel: top view of the $6 \mathrm{MR}$; lower panel: perspective view of the two connected d6MRs in the SAPO-34 system unit cell containing $2 \mathrm{Si}$

\section{Ab-initio phase diagrams of copper speciation}

To investigate the relative stabilities of the various copper species the DFT results needs to be extended to relevant finite temperatures and atmospheres. Therefore an approach similar to [102-104] and in particular based on [105] was applied in order to develop expressions for the Gibbs free energy of the various copper species depending on $\mathrm{T}, \mathrm{p}_{\mathrm{O}_{2}}$ and $\mathrm{p}_{\mathrm{H}_{2} \mathrm{O}}$.

The Gibbs free energy of a solid, for the conditions relevant in this case, can be written as $g_{\text {solid }} \approx E_{\text {solid }}$, where $E_{\text {solid }}$ corresponds to the DFT energies.[102105] This is done assuming that the contribution from framework vibrations is small and that the Helmholtz free energy mainly depends on the electronic energy of the system. In this way the free energy of the various copper species 
can be expressed by equation 5.2 and $5.3^{1}$

$$
\begin{aligned}
g_{\mathrm{CuOH}(\mathrm{H} 2 \mathrm{O})_{\mathrm{n}}-\mathrm{Z}}= & E_{\mathrm{CuOH}(\mathrm{H} 2 \mathrm{O})_{\mathrm{n}}-\mathrm{Z}}-E_{\mathrm{H}-\mathrm{Z}}-E_{\mathrm{Cu}} \\
& -0.5 \cdot \mu_{\mathrm{O}_{2}}\left(T, p_{\mathrm{O}_{2}}\right)-n \cdot \mu_{\mathrm{H}_{2} \mathrm{O}}\left(T, p_{\mathrm{H}_{2} \mathrm{O}}\right) \\
g_{\mathrm{Cu}(\mathrm{H} 2 \mathrm{O})_{\mathrm{n}}-\mathrm{Z}}= & E_{\mathrm{Cu}(\mathrm{H} 2 \mathrm{O})_{\mathrm{n}}-\mathrm{Z}}-E_{\mathrm{H}-\mathrm{Z}}-E_{\mathrm{Cu}} \\
& -0.25 \cdot \mu_{\mathrm{O}_{2}}\left(T, p_{\mathrm{O}_{2}}\right) \\
& +(0.5-n) \cdot \mu_{\mathrm{H}_{2} \mathrm{O}}\left(T, p_{\mathrm{H}_{2} \mathrm{O}}\right)
\end{aligned}
$$

where $\mathrm{H}-\mathrm{Z}$ refers to the the $\mathrm{H}$-form of the zeolite or zeotype and $\mathrm{Cu}$ is metallic copper. In the equations $\mu$ is the chemical potential of gasses and a function of the temperature $T$ as well as the pressure $p$. To include these correctly, they should also be expressed using the DFT energies and may be written according to:

$$
\begin{aligned}
\mu_{\text {gas }}(T, p)= & \mu_{\text {gas }}\left(T, p^{0}\right)+k_{\mathrm{B}} T \ln \left(\frac{p}{p^{0}}\right) \\
= & \Delta h_{\text {gas }}\left(T, p^{0}\right)+E_{\text {gas }}^{\text {vib }}(T=0 \mathrm{~K})+E_{\text {gas }} \\
& -T S_{\text {gas }}\left(T, p^{0}\right)+k_{\mathrm{B}} T \ln \left(\frac{p}{p^{0}}\right)
\end{aligned}
$$

In equation $5.4 \Delta h_{\text {gas }}\left(T, p^{0}\right)$ and $S_{\text {gas }}\left(T, p^{0}\right)$ can be found in standard thermodynamic tables[106] when $p^{0}=1$ bar and $E_{\text {gas }}^{v i b}(T=0 \mathrm{~K})$ can either be calculated by DFT, as done here, or found from experimental results.

When the above system of equations is used the relative Gibbs free energies for the various copper species can be compared.

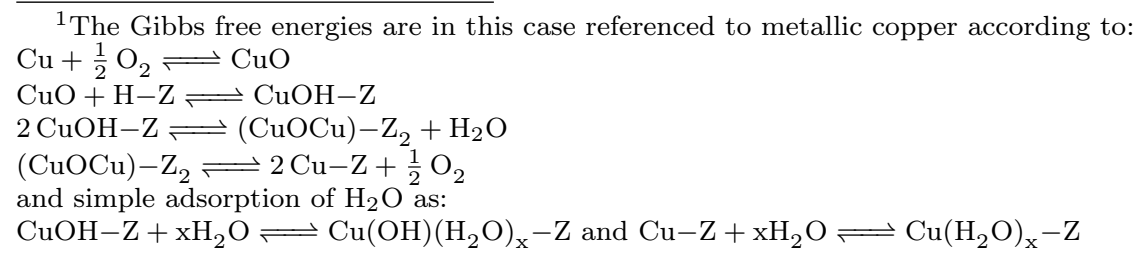



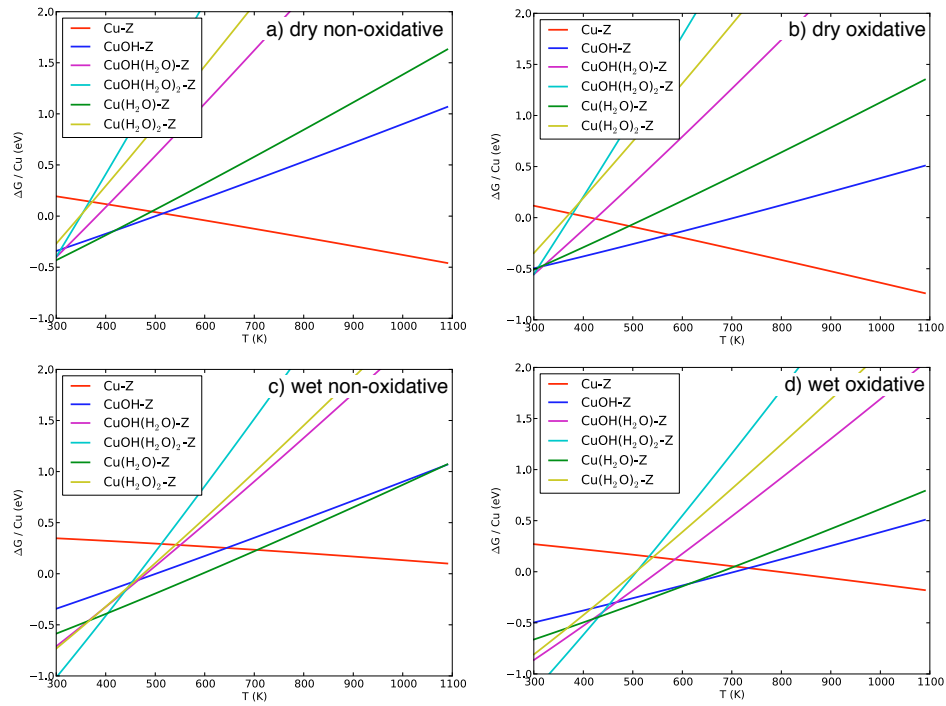

Figure 5.5: Ab-inito calculated phase diagrams showing the relative stabilities of the various copper species in SAPO-34 depending on the atmosphere: a) dry non-oxidative conditions $\left(p_{\mathrm{H}_{2} \mathrm{O}}=1 \cdot 10^{-6}\right.$ bar, $p_{\mathrm{O}_{2}}=1 \cdot 10^{-6}$ bar $)$, b) dry oxidative conditions $\left(p_{\mathrm{H}_{2} \mathrm{O}}=1 \cdot 10^{-6}\right.$ bar, $\left.p_{\mathrm{O}_{2}}=0.15 \mathrm{bar}\right)$, c) wet non-oxidative conditions $\left(p_{\mathrm{H}_{2} \mathrm{O}}=1 \cdot 10^{-6} \mathrm{bar}, p_{\mathrm{O}_{2}}=0.15 \mathrm{bar}\right)$ and $\left.\mathrm{d}\right)$ wet oxidative conditions $\left(p_{\mathrm{H}_{2} \mathrm{O}}=0.15\right.$ bar, $p_{\mathrm{O}_{2}}=0.15$ bar $)$

Gibbs free energies of the various copper species are shown in Figure 5.5 for four relevant atmospheres: dry non-oxidative, dry oxidative, wet non oxidative and wet oxidative. In general, the most stable species under the given conditions is the one with the lowest Gibbs free energy. From the phase diagrams in Figure 5.5 it can be noticed that the most stable species at low temperature (300-400 K) depends on the specific atmosphere to a great extent. Under wet conditions hydrated copper hydroxide species $\left[\mathrm{CuOH}\left(\mathrm{H}_{2} \mathrm{O}\right)\right]$ dominate. Under dry conditions the identity of species depend to a greater extent on the pressure of oxygen and the dominant species are either $[\mathrm{CuOH}]$ or $\left[\mathrm{Cu}\left(\mathrm{H}_{2} \mathrm{O}\right)\right]$ under dry oxidative or dry non-oxidative conditions respectively. At intermediate temperatures (400-750 K) even more complex behavior is observed. However, at higher temperatures $(>750 \mathrm{~K})$ the bare copper ion is favored in all cases as a consequence of the entropic contribution from $\mathrm{H}_{2} \mathrm{O}$ and $\mathrm{O}_{2}$ in the gas phase. 
On a qualitative basis the phase diagrams explain several features observed experimentally for $\mathrm{Cu}$-zeolites. In particular the phase diagrams show that depending on the atmosphere and temperature of pretreatment different copper species will dominate. This could be one reason for some of the many conflicting characterization results in literature. An example is the pretreatment of $\mathrm{Cu}$-zeolites in vacuum or in oxygen at elevated temperatures that gives $[\mathrm{Cu}$ ] and $[\mathrm{CuOH}]$ species respectively as recently described from FTIR measurements with different probe molecules.[48]

Another interesting feature in the phase diagrams is the difference in stability at higher temperatures. The rate of migration of any of the copper species that are not the most favored will be proportional to a function of the difference in stability between these species. In all cases the $[\mathrm{Cu}]$ species is most favored at higher temperatures, but under wet conditions the difference between $[\mathrm{Cu}]$ and $[\mathrm{CuOH}]$ as well as $\left[\mathrm{Cu}\left(\mathrm{H}_{2} \mathrm{O}\right)\right]$ become smaller.

\section{Copper species and proton migration in SAPO-34}

Since the bare copper ion is the most stable species at higher temperatures in the SAPO-34 system, this is the starting point for the investigation. The migration in all the following cases involves two overall mechanisms: i) migration of the $\mathrm{Cu}$-species from the bottom 6-MR environment containing one Si atom to the top 6-MR and ii) migration of the proton from the top 6-MR down to the bottom 6-MR (the original location of the $\mathrm{Cu}$-species). 


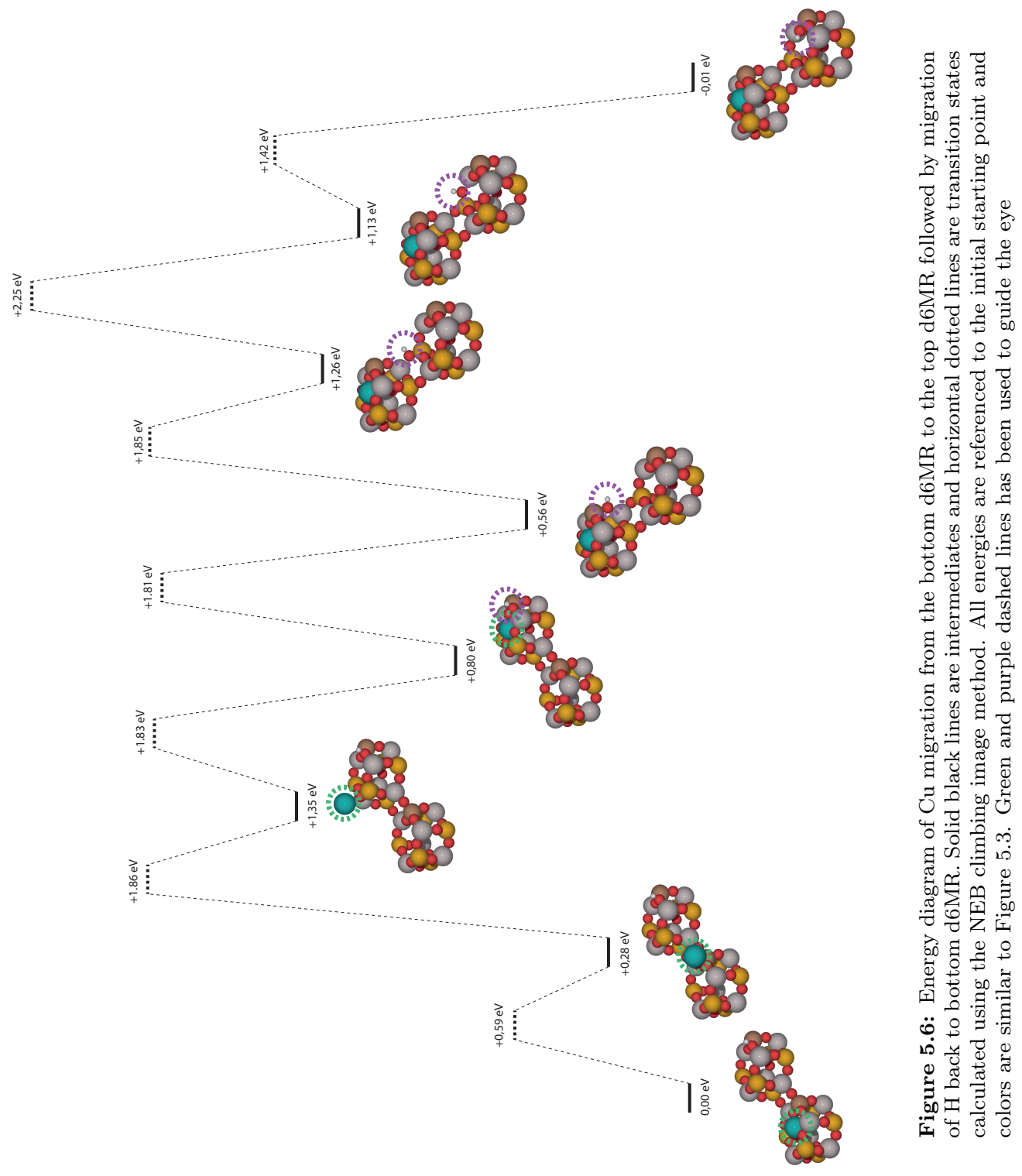


To investigate possible migration paths intermediates were initially identified based on several different qualified guesses followed by relaxation of all atom positions. Based on these intermediates various migration paths were investigated, where the transition state between each initial and final image was found using the nudged elastic band and climbing image method (as described in section 5.2.3). The minimum energy path found for the migration of the bare copper ion and proton is shown in Figure 5.6. It was found that migration of the copper ion around the initial Si environment and out of the plane of the 6-MR involves a barrier of ca. $0.6 \mathrm{eV}$. As soon as the copper migrates away from the $\mathrm{Si}$ environment the negative charge of the framework is no longer balanced by the $\mathrm{Cu}$ ion and barriers of 1.8-1.9 eV are found. These can vary slightly depending on the path. The final location of the copper is found when it encounters the second $\mathrm{Si}$ environment where the copper again becomes located in the plane of the 6-MR. This constellation can be slightly more stabilized by migration of the proton away from the 6-MR and down the side of the hexagonal prism (d6MR). To finalize the migration, the proton should then migrate down to the lower 6 -MR. This migration is however not easy and the largest barrier of $2.25 \mathrm{eV}$ is found when the proton is furthest away from the two Si environments; that is when it migrates from the first oxygen atom to the next of the middle $\mathrm{P}$ tetrahedra. Afterwards smaller barriers are encountered and the migration is completed when the proton becomes coordinated to one of the $\mathrm{O}$ atoms around the $\mathrm{Si}$ atom in the lower 6-MR, where the system reaches the same energy as the initial state.

The observations from the migration of the copper ion and the proton are interesting, because they show that it is not the migration of the copper cation, but instead it is the migration of the proton that is limiting for this system.

Migration in the $[\mathrm{CuOH}]$ system is slightly different. The minimum energy path involves smaller barriers for the migration of $[\mathrm{CuOH}]$ as compared to $[\mathrm{Cu}]$ either because $[\mathrm{CuOH}]$ follow a slightly different path between the two Si-atoms, or because the copper is charge balanced by the $\mathrm{OH}$ ligand. This is expressed in the barriers of ca. $1.4 \mathrm{eV}$ for $[\mathrm{CuOH}]$ migration between sites not directly associated with a Si environment. Another feature in this migration is that the $[\mathrm{CuOH}]$ is able to pick up the proton when it reaches the location in the new 6 -MR. This leads to a stable intermediate only $0.2 \mathrm{eV}$ higher in energy than the initial and final state. 


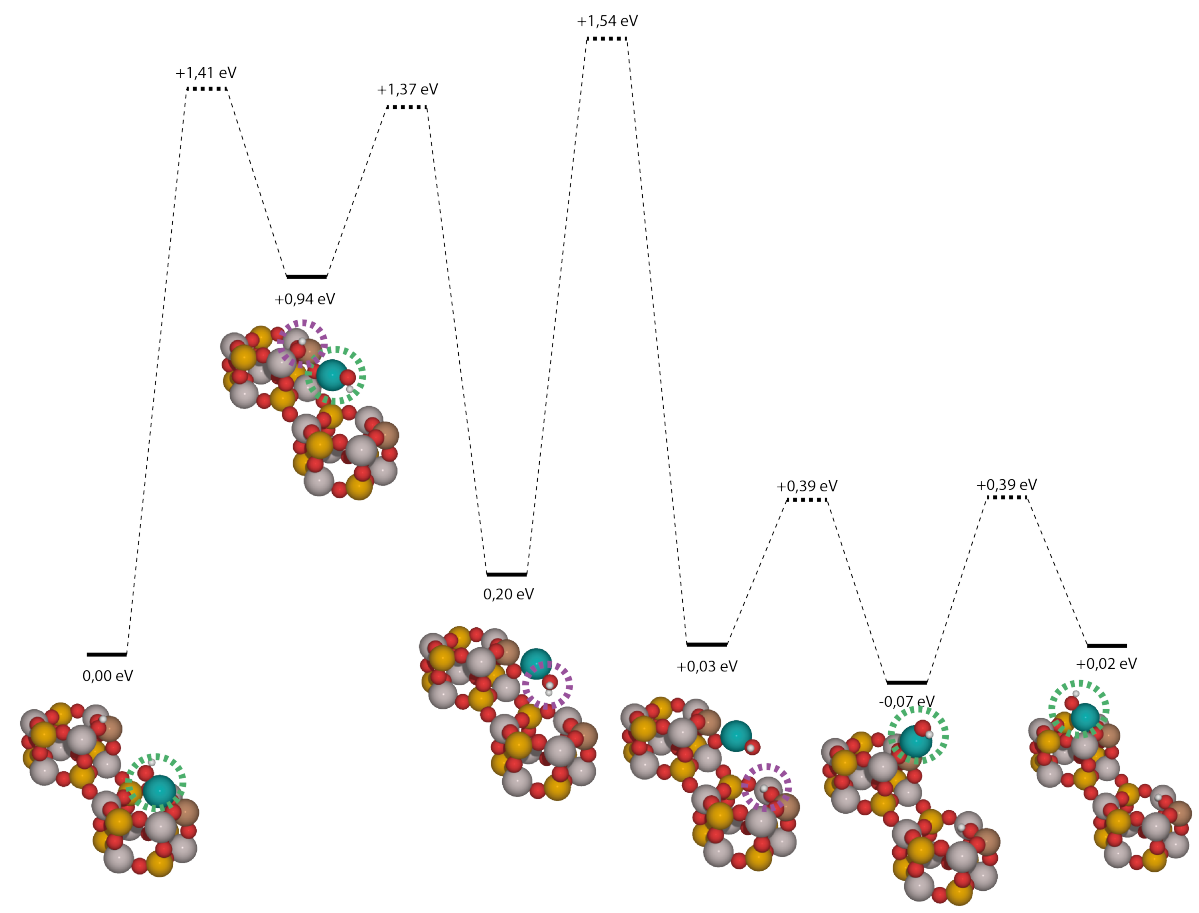

Figure 5.7: Energy diagram of $\mathrm{CuOH}$ migration from the bottom d6MR to the top d6MR followed by migration of $\mathrm{H}$ back to the original location $\mathrm{CuOH}$ species in the bottom d6MR. Notice that the $\mathrm{H}$ migration is facilitated by the $\mathrm{CuOH}$. Solid black lines are intermediates and horizontal dotted lines are transition states calculated using the NEB climbing image method. All energies are referenced to the initial starting point and colors are similar to Figure 5.3

Another important feature in the $[\mathrm{CuOH}]$ system is the ability of $[\mathrm{CuOH}]$ to form the above-mentioned stable $\left[\mathrm{CuOH}_{2}\right]$ intermediate that is able to facilitate the proton migration. By forming the $\left[\mathrm{CuOH}_{2}\right]$ intermediate, the proton migration is lowered to $1.54 \mathrm{eV}$ in the $[\mathrm{CuOH}]$ system, which is approximately $0.7 \mathrm{eV}$ lower than for the other two species. After the proton migration is facilitated, the $[\mathrm{CuOH}]$, now located close to the upper silicon atom, can migrate around this environment. Almost identically stable configurations around the final Sienvironment are found and migration between them is separated by barriers of $0.4 \mathrm{eV}$. In fact we also find a configuration that is slightly more stable by 0.07 
$\mathrm{eV}$ than the ones initially investigated.

In the $\left[\mathrm{Cu}\left(\mathrm{H}_{2} \mathrm{O}\right)-\mathrm{Z}\right]$ system the limiting step is again related to the migration of the proton. In this case $\left[\mathrm{Cu}\left(\mathrm{H}_{2} \mathrm{O}\right)\right]$ can also facilitate the proton transfer by delivering a proton to the bottom Si site with a barrier very similar to the one for $[\mathrm{CuOH}]$ cf. Figure 5.8. The recombination with the new proton does however involve a barrier of $2.23 \mathrm{eV}$, which is limiting in this case.

Overall the largest barriers in the minimum energy paths are summarized in Table 5.3. All barriers are large and, as noted earlier, involve migration of a proton. The $[\mathrm{CuOH}]$-system show a significantly lower barrier than the other systems because of the facilitated proton migration.

Table 5.3: Largest barriers in the minimum energy path for various copper species in the SAPO-34 system and characteristics of the mechanism. Transition states were found using the nudged elastic band and climbing image methods. Further DFT calculation details can be found in section 5.2.3

\begin{tabular}{lll}
\hline Migration system & $E^{\ddagger}(\mathrm{eV})$ & Characteristic \\
\hline$[\mathrm{Cu}]-\mathrm{Z}$ & 2.25 & non-facilitated proton migration \\
{$\left[\mathrm{Cu}\left(\mathrm{H}_{2} \mathrm{O}\right)\right]-\mathrm{Z}$} & 2.23 & reformation of $\left[\mathrm{Cu}\left(\mathrm{H}_{2} \mathrm{O}\right)\right]$ after proton migration \\
{$[\mathrm{CuOH}]-\mathrm{Z}$} & 1.54 & {$[\mathrm{CuOH}]$ facilitated proton migration } \\
\hline
\end{tabular}




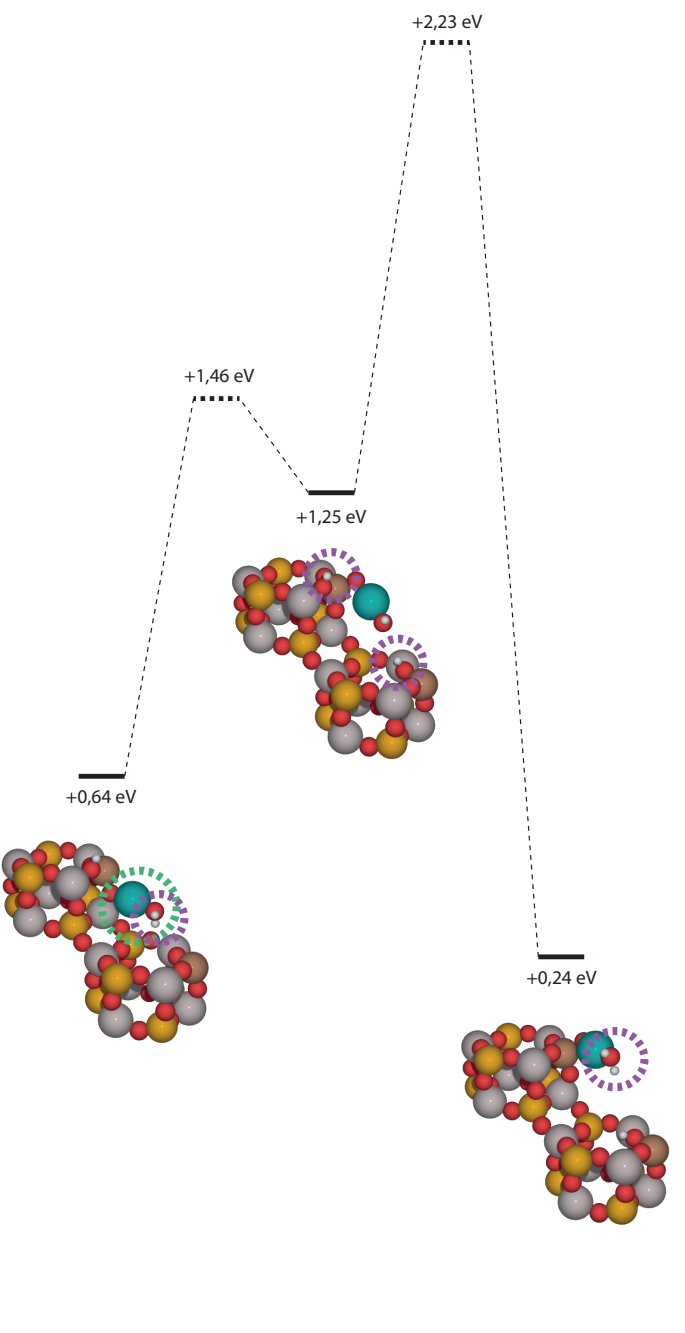

Figure 5.8: Energy diagram of $\mathrm{Cu}\left(\mathrm{OH}_{2}\right)$ facilitating the migration of $\mathrm{H}$ to the bottom d6MR followed by recombination with $\mathrm{H}$. Solid black lines are intermediates and horizontal dotted lines are transition states calculated using the NEB climbing image method. All energies are referenced to the initial starting point and colors are similar to Figure 5.3 
It is important to emphasize that the DFT model only describes the migration of copper species and a proton in one specific environment. If the $\mathrm{Si}$ atoms are located in different positions the copper species and proton could follow different migration paths. The model does however help to illustrate that the proton migration is most likely the limiting step in order to close the cycle. For this reason anything that will facilitate the proton migration will facilitate the activation of Cu-SAPO-34 materials and for this reason increase the catalytic activity. Several prior studies on zeolites have investigated the migration of protons, and as found in the above, also show the positive influence of water on proton migration in general.[107-110].

\subsubsection{Catalytic evaluation of Cu-SAPO-34 after activation in different atmospheres}

The migration mechanisms presented earlier show that formation of $[\mathrm{CuOH}]-$ species facilitate proton migration and thereby also the $\mathrm{Cu}$-migration. This is most easily accomplished under wet conditions according to the phase diagrams as the difference between Gibbs free energies are small under these conditions.

The impact of the atmosphere in the activation on Cu-SAPO-34 catalytic performance is reported in Table 5.4. The results show a similar increase in activity upon thermal activation under dry conditions, which was also seen in chapter 4 . However, upon activation under wet conditions a further increase is observed in activity by $20-31 \%$. It may additionally be noted that the increase in activity is in good agreement with the amount of $\mathrm{Si}$ without $\mathrm{Si}-\mathrm{NNN}$ calculated in section 5.3.1, and that the improvements are only obtained under wet conditions as also suggested by the DFT model.

\subsection{Summary and Conclusions}

A combination of experimental characterization (ICP and ${ }^{29}$ Si-MAS-NMR) and a binomial distribution model was applied to estimate the amount of $\mathrm{Si}$ without any next nearest neighbors in SAPO-34. These results indicated that between 8 and $17 \%$ of the Si exist separated by more than one $\mathrm{P}$ and two Al tetrahedra in the specific material applied here. It was further speculated that activation, in the form of cation migration between such sites, requires higher temperatures than typical calcination temperatures as it was also observed in Chapter 4. 
Table 5.4: Activity ( $\mathrm{k}_{\mathrm{NO}}$ based on pseudo-first order kinetics) for the $\mathrm{NH}_{3}$ $\mathrm{SCR}$ reaction over $\mathrm{Cu}-\mathrm{SAPO}-34$ activated in different atmospheres at $750{ }^{\circ} \mathrm{C}$ for $3 \mathrm{~h}$. Test conditions were: $500 \mathrm{ppm} \mathrm{NO}, 530 \mathrm{ppm} \mathrm{NH}, 10 \% \mathrm{O}_{2}, 5 \%$ $\mathrm{H}_{2} \mathrm{O}$, balance $\mathrm{N}_{2}$ to a total flow of $300 \mathrm{NmL} / \mathrm{min}$ and $10 \mathrm{mg} \mathrm{Cu}-\mathrm{SAPO}-34$ $(1.2$ wt. $\% \mathrm{Cu})$

\begin{tabular}{lc}
\hline Activation atmosphere & $\mathrm{k}_{\mathrm{NO}} \cdot 10^{3}\left(\mathrm{~mol} \cdot \mathrm{g}^{-1} \cdot \mathrm{bar}^{-1} \cdot \mathrm{s}^{-1}\right)$ at $180{ }^{\circ} \mathrm{C}$ \\
\hline no activation & 0.59 \\
$\mathrm{~N}_{2}$ & 2.29 \\
$\mathrm{~N}_{2}+15 \% \mathrm{O}_{2}$ & 2.16 \\
$\mathrm{~N}_{2}+15 \% \mathrm{O}_{2}+15 \% \mathrm{H}_{2} \mathrm{O}$ & 2.74 \\
$\mathrm{~N}_{2}+15 \% \mathrm{H}_{2} \mathrm{O}$ & 2.84 \\
\hline
\end{tabular}

From DFT calculations ab initio phase diagrams were constructed showing the relative stabilities of various copper species in SAPO-34. At high temperatures $(>700 \mathrm{~K})$ it was found that irrespective of the atmosphere the a bare copper ion is most stable. The relative stability of the second most stable species however depends on the atmosphere, where wet conditions favor $[\mathrm{CuOH}]$-type species. Possible migration paths of relevant cations in SAPO-34 using DFT calculations combined with the nudged elastic band and climbing image methods were hereafter presented. Interestingly, it was found that it is not the copper migration that is rate determining for the overall migration. Instead it is the migration of the charge compensating proton that appear to be rate determining. The results from the migration studies showed that $[\mathrm{CuOH}]$ specifically is able to facilitate this migration. However, anything that improves proton migration should facilitate the activation of $\mathrm{Cu}-\mathrm{SAPO}-34$ catalysts.

To verify the theoretical investigations, activation of $\mathrm{Cu}-\mathrm{SAPO}-34$ was experimentally carried out in different atmospheres containing $\mathrm{N}_{2}, \mathrm{O}_{2}, \mathrm{H}_{2} \mathrm{O}$ and combinations thereof. Catalytic results in the $\mathrm{NH}_{3}-\mathrm{SCR}$ reaction after activation in dry atmospheres showed similar activities as observed earlier in Chapter 4, but in wet atmospheres the proton migration was facilitated and a further 20-31 $\%$ increase in activity could be observed, which is in good agreement with an estimate of the amount of Si without any next-nearest neighbors. 
CHAPTER 6

\section{Hydrothermal deactivation of $\mathrm{Cu}-\mathrm{ZSM}-5$ and $\mathrm{Cu}-\mathrm{IM}-5$ zeolites and impact on $\mathrm{NH}_{3}$-SCR performance}

This chapter is adapted from the publication:

P.N.R. Vennestrøm, T.V.W. Janssens, A. Kustov, M. Grill, A. Puig-Molina, L.F. Lundegaard, R.R. Tiruvalam, P. Concepcion, A. Corma, "Influence of lattice stability on hydrothermal deactivation of Cu-ZSM-5 and Cu-IM-5 zeolites for selective catalytic reduction of $\mathrm{NO}_{\mathrm{x}}$ by $\mathrm{NH}_{3}$ ", J.Catal., 2014, 309, 477

\subsection{Introduction}

$\mathrm{Cu}$-zeolites are in general more active at lower temperatures in the $\mathrm{NH}_{3}$-SCR reaction than their Fe-equivalents, but they also deactivate faster. [68] The rapid deactivation under hydrothermal conditions is one of the biggest challenges for the commercial use of $\mathrm{Cu}$-zeolites, and a better understanding of the deactivation mechanism is required in order to improve the stability.

Several theories have been presented on the deactivation mechanism of metal exchanged zeolites. The best understanding of hydrothermal deactivation of transition metal exchanged zeolites has so far been obtained for Fe-ZSM-5, where the overall deactivation has been coupled to the stability of the Fe-species within 
the zeolite and not the framework stability alone.[111, 112] The situation seems to be different for $\mathrm{Cu}$-zeolites and especially the framework stability may play a significant role in this case.

In earlier work from Grinsted et al. and Cheng et al. they relate the deactivation of Cu-ZSM-5 to dealumination of the zeolite framework, $[26,113]$ and Palella et al. observed extra-framework $\mathrm{Al}^{3+}$ and the loss of monovalent copper after mild hydrothermal aging.[114] In addition Yan et al. discuss the formation of $\mathrm{CuO}$ and $\mathrm{Al}_{2} \mathrm{O}_{3}$, which can irreversibly form $\mathrm{CuAl}_{2} \mathrm{O}_{4}$ under severe aging conditions,[115] which is in agreement with the study by Kwak et al. who showed a strong interaction between $\mathrm{Cu}$ and $\mathrm{Al}$ after severe hydrothermal treatments in $\mathrm{Cu}$-zeolites.[42] Other authors have suggested the formation of $\mathrm{CuO}$ and $\mathrm{Cu}_{2} \mathrm{O}$, which leads to local destruction of the framework.[116] Even migration of copper species to inaccessible sites have been reported earlier as an explanation for the loss in catalytic activity.[117]

It is the aim of the present chapter to disentangle the contributions from dealumination and copper migration to deactivation under hydrothermal conditions, as these appear to the be the main contributors according to the data found in literature. To accomplish this task, ZSM-5 and IM-5 were used because they have very similar zeolite framework topologies, but have different reported stabilities towards dealumination.[28, 118]. For these two frameworks the influence of $\mathrm{Al}$ stability on the hydrothermal deactivation is investigated. To achieve this, $\mathrm{Cu}$-zeolite samples are exposed to accelerated hydrothermal aging conditions at 650 and $750{ }^{\circ} \mathrm{C}$ and their catalytic performance evaluated before and after. Afterwards, the catalytic performance is correlated with material changes obtained from various characterization techniques. $\mathrm{N}_{2}$-physisorption $\mathrm{NH}_{3}-\mathrm{TPD}$ and ${ }^{27} \mathrm{Al}-$ MAS-NMR is used to characterize changes to the framework and XAFS, FTIR and $\mathrm{H}_{2}$-TPR techniques is used to monitor changes in copper speciation. As a reference to the changes in material and catalytic performance various copper containing phases are also tested in the SCR reaction and TEM/EDS is used to verify the migration of copper ions from $\mathrm{CuO}$ into zeolite ion exchange positions. Based on the findings an overall deactivation scheme is proposed for Cu-ZSM-5 and $\mathrm{Cu}-\mathrm{IM}-5$. 


\subsection{Experimental}

For the synthesis of the IM-5 zeolite, a similar approach reported earlier was adapted,[118, 119] using a gel composition including IM-5 seeds to avoid contamination by impurity phases. The synthesis gel composition was:

$$
60 \mathrm{SiO}_{2}: 3 \mathrm{Al}: 17 \mathrm{Na}_{2} \mathrm{O}: 6 \mathrm{NaBr}: 10 \mathrm{R}: 2400 \mathrm{H}_{2} \mathrm{O} \text {, }
$$

where $\mathrm{R}$ is the template 1,5 -bis(N-methylpyrrolidinium)pentane $(1,5$-MPP) prepared prior to zeolite synthesis. In a typical synthesis $18.01 \mathrm{~g} 1,5-\mathrm{MPP}$ was dissolved in $114.50 \mathrm{~g} \mathrm{H}_{2} \mathrm{O}$ followed by addition of $15.41 \mathrm{~g}$ Si-aerosol (Degussa 200). In a second container $2.78 \mathrm{~g} \mathrm{NaBr}(98-100.5 \%$, Scharlau) and $6.12 \mathrm{~g} \mathrm{NaOH}$ (>98\%, Scharlau) were dissolved in $68.12 \mathrm{~g} \mathrm{H}_{2} \mathrm{O}$. Afterwards $0.36 \mathrm{~g}$ Al-foil was added and the mixture was left under stirring for $16 \mathrm{~h}$ to digest. The clear solution was then added slowly to the first solution under stirring for $30 \mathrm{~min}$. Finally $0.81 \mathrm{~g}$ IM-5 seeds suspended in $12.00 \mathrm{~g} \mathrm{H}_{2} \mathrm{O}$ were added. The zeolite gel was then transferred to Teflon lined autoclaves, sealed and heated to $175{ }^{\circ} \mathrm{C}$ for seven days. The zeolite product was recovered by suction filtration and calcined at $580{ }^{\circ} \mathrm{C}$ for $3 \mathrm{~h}$ after drying. To convert the zeolite into the $\mathrm{NH}_{4}$-form it was ion exchanged two times in $2.5 \mathrm{M} \mathrm{NH}_{4} \mathrm{Cl}$ for $2 \mathrm{~h}$ at $80{ }^{\circ} \mathrm{C}$ under reflux in a solid to liquid ratio of $10(\mathrm{w} / \mathrm{w})$.

The $\mathrm{NH}_{4}-\mathrm{ZSM}-5$ was obtained from a commercial supplier. To introduce $\mathrm{Cu}$ into the zeolites, the $\mathrm{NH}_{4}$-form of the IM-5 and ZSM-5 zeolites were ion exchanged with $\mathrm{Cu}\left(\mathrm{CH}_{3} \mathrm{COO}\right)_{2} \cdot \mathrm{H}_{2} \mathrm{O}(>99.0 \%$, SigmaAldrich) at different molarities and consecutive times, to obtain $\mathrm{Cu} / \mathrm{Al}$ ratios above 0.5 , at room temperature using $250 \mathrm{~mL} / \mathrm{g}$ under stirring for $24 \mathrm{~h}$ to obtain varying copper loads on the two zeolites. After ion-exchange, all samples were calcined at $500{ }^{\circ} \mathrm{C}$ for $3 \mathrm{~h}$. From these series three samples of each zeolite containing a comparable low, medium, and high $\mathrm{Cu}$-loadings were selected. Each sample was then divided into three portions. The first portion was used without further treatment, the second and third portions were aged in the exhaust of a diesel burner containing ca. $10 \%$ $\mathrm{H}_{2} \mathrm{O}$ and $8 \% \mathrm{O}_{2}$ for $16 \mathrm{~h}$ at $650{ }^{\circ} \mathrm{C}$ and $750{ }^{\circ} \mathrm{C}$, respectively.

Reference samples were prepared by physically mixing $\mathrm{CuO}$ (Riedel de-Haën, $>99 \%$ ), $\mathrm{Cu}_{2} \mathrm{O}$ (Sigma-Aldrich, $<5 \mu \mathrm{m}, 97 \%$ ) or $\mathrm{CuAl}_{2} \mathrm{O}_{4}$ with the parent H-ZSM-5 zeolite in a mortar and grinding it for $10 \mathrm{~min}$. The $\mathrm{CuAl}_{2} \mathrm{O}_{4}$ was prepared by heating a mixture of $\mathrm{CuNO}_{3} \cdot 3 \mathrm{H}_{2} \mathrm{O}$ and pseudoboehmite ( $\mathrm{Al}: \mathrm{Cu}$ molar ratio $2: 1$ ), at $800{ }^{\circ} \mathrm{C}$ for $3 \mathrm{~h}$

The selective catalytic reduction of $\mathrm{NO}$ by ammonia $\left(\mathrm{NH}_{3}-\mathrm{SCR}\right)$ was carried out in a fixed bed quartz reactor (i.d. $4 \mathrm{~mm}$ ) using $40 \mathrm{mg}$ catalyst $(150-300 \mu \mathrm{m}$ 
fraction) diluted with $180 \mathrm{mg} \mathrm{SiC}$. The reactant gas composition was a typical

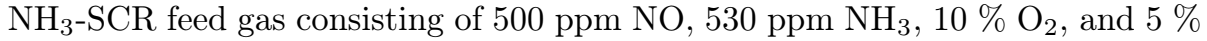
$\mathrm{H}_{2} \mathrm{O}$, balanced with $\mathrm{N}_{2}$. The total flow rate was maintained at $285 \mathrm{NmL} / \mathrm{min}$. Prior to the activity measurements, the samples were treated in the reaction mixture for $1 \mathrm{~h}$ at $550{ }^{\circ} \mathrm{C}$. The activity test was carried out by ramping the temperature down from 550 to $170{ }^{\circ} \mathrm{C}$, at $2{ }^{\circ} \mathrm{C} / \mathrm{min}$. The outlet gas was analyzed for $\mathrm{NO}, \mathrm{NO}_{2}, \mathrm{NH}_{3}, \mathrm{~N}_{2} \mathrm{O}$ and $\mathrm{H}_{2} \mathrm{O}$ by a Gasmet CX4000 FTIR analyzer equipped with a Peltier cooled MCT detector.

The zeolite phases and crystallinity were investigated by X-ray diffraction, measured on a multisample PANalytical X'Pert diffractometer using the characteristic $\mathrm{Cu} \mathrm{K} \alpha$ wavelength (1.542 $\AA$ ). Sample elemental composition was measured after acid-digestion by ICP-OES on a Varian 715-ES instrument. Crystallinity of the samples were obtained by the integrated intensity of five selected and isolated reflections for each zeolite. For Cu-ZSM-5 the $(1,0,1),(3,2,2),(1,4,2)$, $(3,1,3)$ and $(5,3,2)$ reflections were used and for Cu-IM-5 the $(0,4,1),(1,13,2)$, $(3,9,0),(3,9,2)$, and $(1,17,2)$ reflections were used.

The micropore volume was analyzed by nitrogen physisorption and performed at liquid nitrogen temperature using a Micromeritics ASAP 2020 instrument. All samples were outgassed in vacuum at $300{ }^{\circ} \mathrm{C}$ for $16 \mathrm{~h}$ prior to measurements. The t-plot method (using a maximum statistical layer thickness of $5.5 \AA$ ) was used to extract micropore volumes.

The morpohology and crystal size were determined by SEM microscopy, recorded on a JEOL JSM-6700F scanning electron microscope using an electron energy of $15 \mathrm{keV}$.

The acidity of the parent zeolite materials were measured by $\mathrm{NH}_{3}$-TPD and performed using $100 \mathrm{mg}$ of sample (150-300 $\mu \mathrm{m}$ sieve fraction) loaded into a fixed bed quartz reactor (i.d. $4 \mathrm{~mm}$ ). First the sample was treated for $2 \mathrm{~h}$ at $500{ }^{\circ} \mathrm{C}$ in a flow of dry nitrogen $(100 \mathrm{NmL} / \mathrm{min})$. Afterwards the sample was saturated with ammonia (4000 ppm $\mathrm{NH}_{3}$ in $\mathrm{N}_{2}$, flow $100 \mathrm{NmL} / \mathrm{min}$ ) at $150{ }^{\circ} \mathrm{C}$ for $1 \mathrm{~h}$, and the weakly adsorbed ammonia was removed in a flow of $\mathrm{N}_{2}$ for 4 $\mathrm{h}$ at the same temperature. Finally the desorption of ammonia was measured using a CX4000 Gasmet FTIR gas analyzer when the temperature was ramped up to $600{ }^{\circ} \mathrm{C}$ at $10^{\circ} / \mathrm{min}$.

Aluminum coordination and environment were measured by ${ }^{27}$ Al-MAS-NMR 
and spectra were recorded on similar sample amounts at $104.2 \mathrm{MHz}$ with a spinning rate of $10 \mathrm{kHz}$ using pulses of $1 \mu \mathrm{s}$, corresponding to a flip magnetization angle $<\pi / 12$ radians with a $1 \mathrm{~s}$ repetition time. ${ }^{27} \mathrm{Al}$ chemical shifts are reported relative to $\mathrm{Al}\left(\mathrm{H}_{2} \mathrm{O}\right)_{6}^{3+}$.

To monitor changes in $\mathrm{OH}$ vibrations, infrared spectra were recorded at -175 ${ }^{\circ} \mathrm{C}$ with a Nexus 8700 FTIR spectrometer using a DTGS detector with $4 \mathrm{~cm}^{-1}$ resolution. An IR cell allowing in situ treatments in controlled atmospheres and temperatures from $-175{ }^{\circ} \mathrm{C} \mathrm{K}$ to $500{ }^{\circ} \mathrm{C}$ was connected to a vacuum system with a gas dosing facility. The catalyst samples were pressed into self-supporting wafers, and dried at $350{ }^{\circ} \mathrm{C}$ in an oxygen flow of $20 \mathrm{ml} / \mathrm{min}$ for $2 \mathrm{~h}$ followed by evacuation at $10^{-4} \mathrm{mbar}$ at $150{ }^{\circ} \mathrm{C}$ for $1 \mathrm{~h}$ to prevent reduction of $\mathrm{Cu}^{2+}$.[120] After this pretreatment the samples were cooled down to $-175{ }^{\circ} \mathrm{C}$

The changes in $\mathrm{Cu}$ coordination and local environment upon dehydration were studied by in-situ EXAFS at the $\mathrm{Cu}-\mathrm{K}$ edge in transmission mode using three ionization chambers for the detection of the incident X-rays. The measurements were performed at beamline X1 (Römo II experimental station) at Hasylab (Hamburg, Germany) and beamline I811 at MAXlab (Sweden). The dehydration of fresh and aged $\mathrm{Cu}$-zeolites (sieved particle fraction $75-125 \mu \mathrm{m}$ ) was followed by placing an in situ reactor cell[121] between the first and second ion chamber. A reference sample located between the second and third ionization chamber was used to calibrate the energy of the XAFS spectra. A double Si(111) crystal monochromator with a slight detuning of the second crystal was used to minimize the presence of higher harmonics. The dehydration experiments consisted of heating the samples to $300{ }^{\circ} \mathrm{C}$ in $20 \% \mathrm{O}_{2}$ and subsequent cooling to room temperature. EXAFS data were collected at room temperature before and after the dehydration treatment. Pre-edge subtraction, background subtraction, and normalization of the experimental X-ray absorption spectra were done using the Athena software package [122] and the EXAFS refinements were performed with the EXCURV98 program [123]. Phase shifts and backscattering factors were calculated ab initio using Hedin-Lundqvist exchange and Von Barth ground state potentials. Refinements were carried out using $\mathrm{k} 3$ weighting in the range of 2.5 to $12.5 \AA^{-1}$. The amplitude reduction factors (AFAC parameters) calibrated from the fit of a bulk $\mathrm{CuO}$ reference were fixed at 0.63 .

The reducibility of the copper in the zeolites was investigated by $\mathrm{H}_{2}$-TPR experiments. $100 \mathrm{mg}$ sample (150-300 $\mu \mathrm{m}$ sieve fraction) was dehydrated in a fixed bed reactor (i.d. $4 \mathrm{~mm}$ ) by heating at $150{ }^{\circ} \mathrm{C}$ for $30 \mathrm{~min}$ in He at a flow of 100 
$\mathrm{NmL} / \mathrm{min}$. The actual reduction was done in $1 \% \mathrm{H}_{2} / \mathrm{He}$ at $50 \mathrm{NmL} / \mathrm{min}$ by heating from $100{ }^{\circ} \mathrm{C}$ to $600{ }^{\circ} \mathrm{C}$ with a heating rate of $5{ }^{\circ} \mathrm{C} / \mathrm{min}$. The hydrogen consumption and water formation were followed using a calibrated mass spectrometer (Balzers GAM400).

Copper migration was monitored by combined transmission electron microscopy (TEM) using energy dispersive X-ray spectroscopy (EDS). Samples for TEM were prepared by dispersing a small amount of the sample in ethanol and placing the suspension onto a molybdenum grid with a lacey carbon support. TEM analyses were carried out in a Philips CM200 microscope using the nano-probe mode. The EDS spectra from each catalyst were accumulated using beam currents of $115 \mathrm{pA}$ with a live time of $200 \mathrm{~s}$. The beam was spread to a diameter of $100 \mathrm{~nm}$ in order to reduce damage to the zeolite crystals.

\subsection{Results and Discussion}

IM-5 was successfully synthesized and the crystallinity and phase was confirmed by XRPD, see Figure 6.1. Based on scanning electron micrographs (SEM) of the parent IM-5 material, a ZSM-5 sample was chosen with similar crystal size (see Figure 6.2) and similar $\mathrm{Si} / \mathrm{Al}$ ratio. Afterwards copper was introduced from aqueous exchange with varying concentrations to obtain similar $\mathrm{Cu}$-loadings for the two zeolites (see Table 6.1).

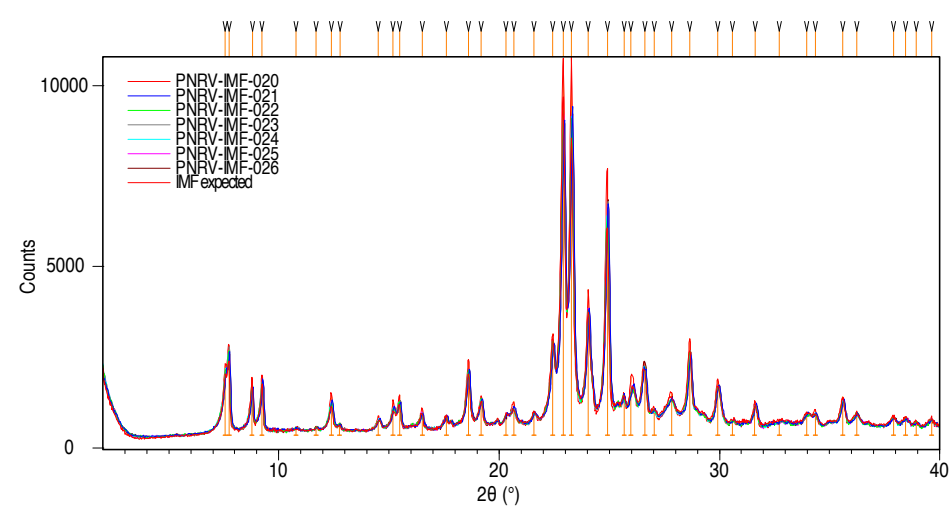

Figure 6.1: X-ray diffractogram of as-synthesized IM-5 zeolites 

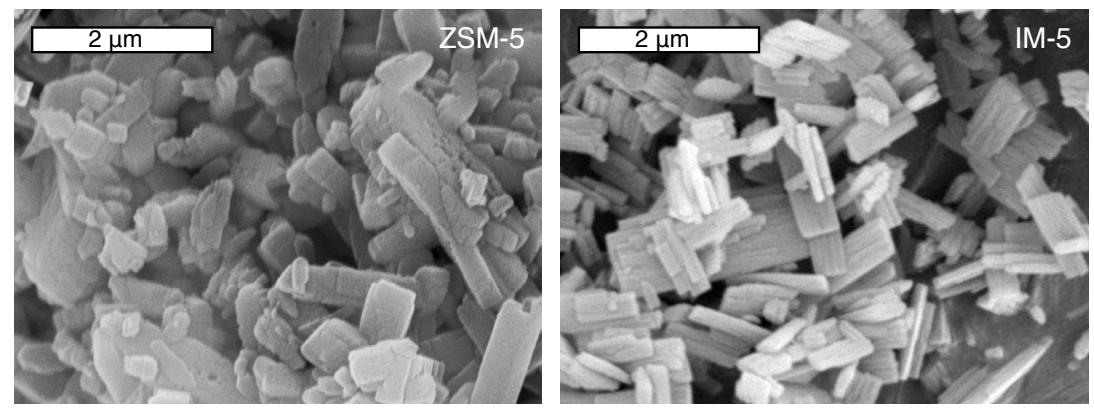

Figure 6.2: Scanning electron micrographs of parent $\mathrm{NH}_{4}-\mathrm{ZSM}-5$ (left) and $\mathrm{NH}_{4}$-IM-5 (right) at similar magnifications

Table 6.1: Copper content of prepared $\mathrm{Cu}-\mathrm{ZSM}-5$ and $\mathrm{Cu}-\mathrm{IM}-5$ samples (and $\mathrm{Si} / \mathrm{Al}$ ratios of parent materials) as well as the micropore volume of fresh samples (calcined at $500{ }^{\circ} \mathrm{C}$ ) and samples hydrothermally treated at $650{ }^{\circ} \mathrm{C}$ and $750{ }^{\circ} \mathrm{C}$ for $16 \mathrm{~h}$

\begin{tabular}{lcccc}
\hline Sample & $\mathrm{Cu} / \mathrm{Al}$ & \multicolumn{3}{c}{$\mathrm{V}_{\text {micro }}\left(\mathrm{cm}^{3} / \mathrm{g}\right)$} \\
& & $500{ }^{\circ} \mathrm{C}$ & $\mathrm{HT} 650{ }^{\circ} \mathrm{C}$ & $\mathrm{HT} 750{ }^{\circ} \mathrm{C}$ \\
\hline ZSM-5 & $\mathrm{Si} / \mathrm{Al}=11.4$ & 0.160 & - & 0.145 \\
$\mathrm{Cu}(0.29)-Z S M-5$ & 0.29 & 0.153 & 0.140 & 0.098 \\
$\mathrm{Cu}(0.43)-Z S M-5$ & 0.43 & 0.144 & 0.140 & 0.088 \\
$\mathrm{Cu}(0.62)-Z S M-5$ & 0.62 & 0.137 & 0.139 & 0.097 \\
$\mathrm{IM}-5$ & $\mathrm{Si} / \mathrm{Al}=10.8$ & 0.167 & - & 0.143 \\
$\mathrm{Cu}(0.28)-\mathrm{IM}-5$ & 0.28 & 0.164 & 0.158 & 0.135 \\
$\mathrm{Cu}(0.44)-\mathrm{IM}-5$ & 0.44 & 0.162 & 0.147 & 0.107 \\
$\mathrm{Cu}(0.62)-\mathrm{IM}-5$ & 0.62 & 0.150 & 0.140 & 0.090 \\
\hline
\end{tabular}

The catalytic conversion of $\mathrm{NO}_{\mathrm{x}}$ (here defined as $\mathrm{NO}+\mathrm{NO}_{2}$ ), $\mathrm{N}_{2} \mathrm{O}$ production and $\mathrm{NO}_{2}$ production in the $\mathrm{NH}_{3}$-SCR reaction over the fresh $\mathrm{Cu}$-zeolites are shown in Figure 6.3a, b and c respectively. The performance of fresh $\mathrm{Cu}-\mathrm{IM}-5$ and $\mathrm{Cu}-\mathrm{ZSM}-5$ at equal $\mathrm{Cu}$-loadings appears to be unaffected by the framework topology. This is a consequence of the similarities between MFI and IMF frameworks both having 10-member-ring pore openings and a similar connectivity in the structure made up from building units containing 6, 5, and 4 T-atoms,[9] which provide similar $\mathrm{Cu}$-coordination environments. For these reasons $\mathrm{Cu}-$ 
ZSM-5 and Cu-IM-5 is a good pair to study the effect of framework stability on the deactivation behavior.

For all catalysts, the $\mathrm{NO}_{\mathrm{x}}$ conversion increases when the temperature increases from 170 to $240{ }^{\circ} \mathrm{C}$ and displays an Arrhenius behavior until the conversion approaches $100 \%$. For both zeolite types, the apparent $\mathrm{NO}_{\mathrm{x}}$ conversion is similar at medium and high $\mathrm{Cu}$ loading, while it is lower for catalysts with a low $\mathrm{Cu}$ loading. This indicates that $\mathrm{NH}_{3}-\mathrm{SCR}$ activity is not limited by the number of copper sites once a certain $\mathrm{Cu}$ loading is reached, which in this case is observed at copper loadings where $\mathrm{Cu} / \mathrm{Al}$ ratios are between 0.3 and 0.45 . Although the $\mathrm{NO}_{\mathrm{x}}$ conversion appear similar, the $\mathrm{N}_{2} \mathrm{O}$ formation around $200{ }^{\circ} \mathrm{C}$ increases monotonically with copper loadings and so does the $\mathrm{NO}_{2}$ production at temperatures above $300{ }^{\circ} \mathrm{C}$. Furthermore, the decrease in observed $\mathrm{NO}_{\mathrm{x}}$ conversion at higher temperatures can be ascribed to unselective oxidation of $\mathrm{NH}_{3}$ with $\mathrm{O}_{2}$ as all the $\mathrm{NH}_{3}$ was converted. As expected this also increase with the copper loading.

The effect of hydrothermal aging at 650 and $750{ }^{\circ} \mathrm{C}$ on $\mathrm{NH}_{3}$-SCR performance is shown for the medium copper loaded Cu-ZSM-5 and $\mathrm{Cu}-\mathrm{IM}-5(\mathrm{Cu} / \mathrm{Al}=0.4)$ in Figure 6.3 together with the fresh performance. Panel $\mathrm{d}$, e and $\mathrm{f}$ show the $\mathrm{NO}_{\mathrm{x}}$ conversion, $\mathrm{N}_{2} \mathrm{O}$ production and $\mathrm{NO}_{2}$ production respectively. Overall behavioral changes in $\mathrm{NO}_{\mathrm{x}}$ conversion upon aging is similar for Cu-ZSM-5 and Cu-IM-5 catalyst, but with some small differences in the extent of deactivation. A decrease in $\mathrm{NO}_{\mathrm{x}}$ conversion is seen after aging at $650{ }^{\circ} \mathrm{C}$ and is more severe for the $\mathrm{Cu}$-ZSM-5 catalyst than the $\mathrm{Cu}-\mathrm{IM}-5$. Aging at $750{ }^{\circ} \mathrm{C}$ causes a further decrease in conversion and is again most severe for the Cu-ZSM-5 catalyst. The same trend is observed for all copper loads as shown in Figure 6.4, where the conversion at $200{ }^{\circ} \mathrm{C}$ is given for all the tested catalysts. In all cases, the performance in terms of $\mathrm{NO}_{\mathrm{x}}$ conversion, has decreased more for Cu-ZSM-5 than in the case of the $\mathrm{Cu}-\mathrm{IM}-5$ when similar copper loadings are compared. 

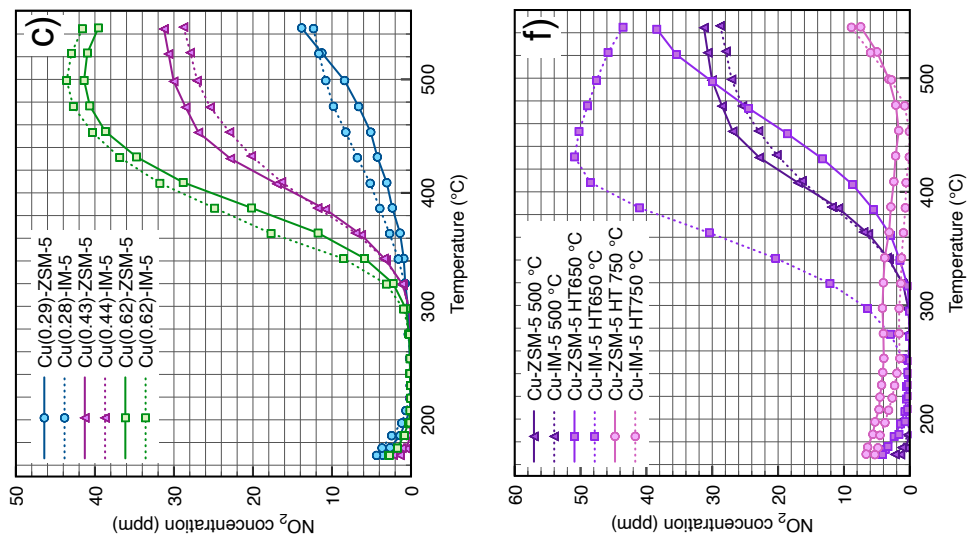

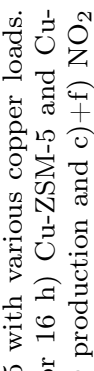

눙요

$\sum_{1}^{1} 0 z^{n}$
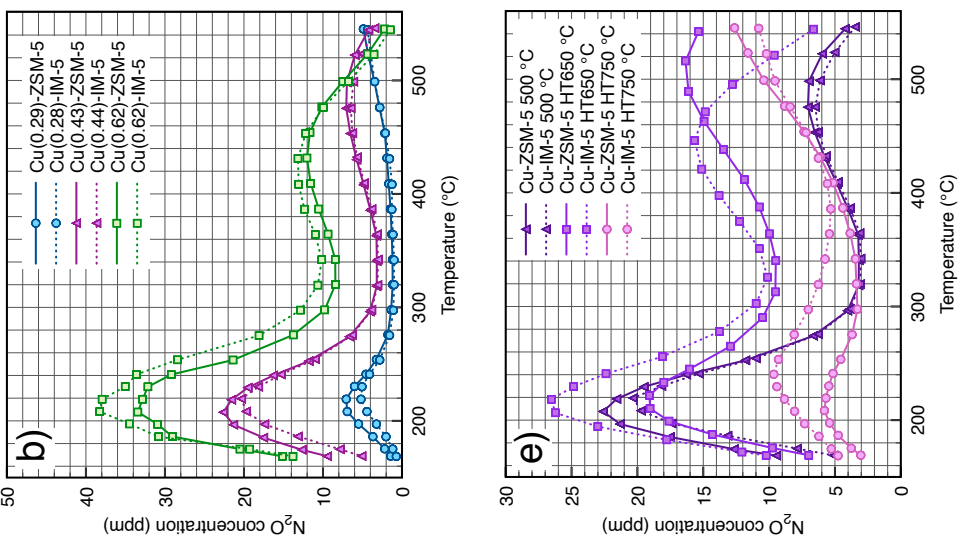

已 용

숭

เป สี

$\sum_{0}^{1} 0$

요욤

记题

대

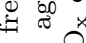

岁

进

可

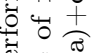

过

중
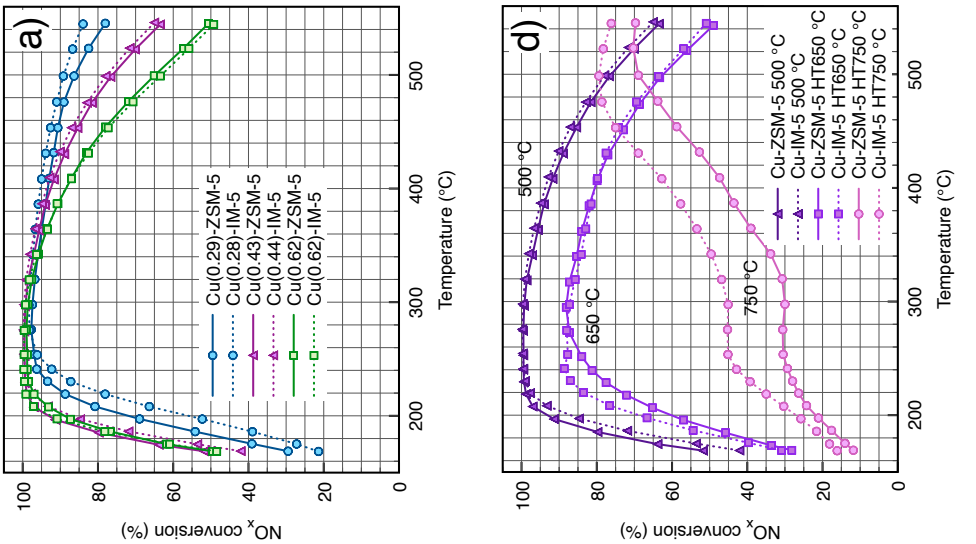

की

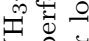

乙苋

हैं 웡

웡혀

产艺

$\ddot{0} \ddot{3}$ घ

웅

면

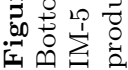

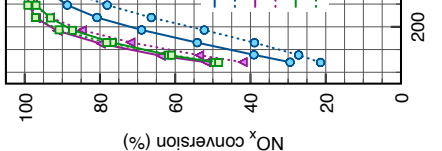


The $\mathrm{NO}_{\mathrm{x}}$ conversion before and after aging shown in Figure 6.4 for all catalysts with different copper loads indicate a stabilizing effect of the copper against deactivation. This is seen by the larger drop in conversion for the catalysts with low copper loads than their high-copper equivalents. A similar conclusion is reached when activities in terms of first-order rate constants are compared. Whether this applies for zeolites in general remains unclear. A stabilizing effect of cations has however been reported before, but seems to depend largely on the identity of the framework and the exchange ion as well as its valency.[124, 125]

A different interpretation may also be followed by considering a certain capacity of sites inaccessible to reactants, which has earlier been discussed by Tanabe et al.[117] If the number of these sites is limited, the consequence would be a relatively larger deactivation for catalysts with low copper loadings.

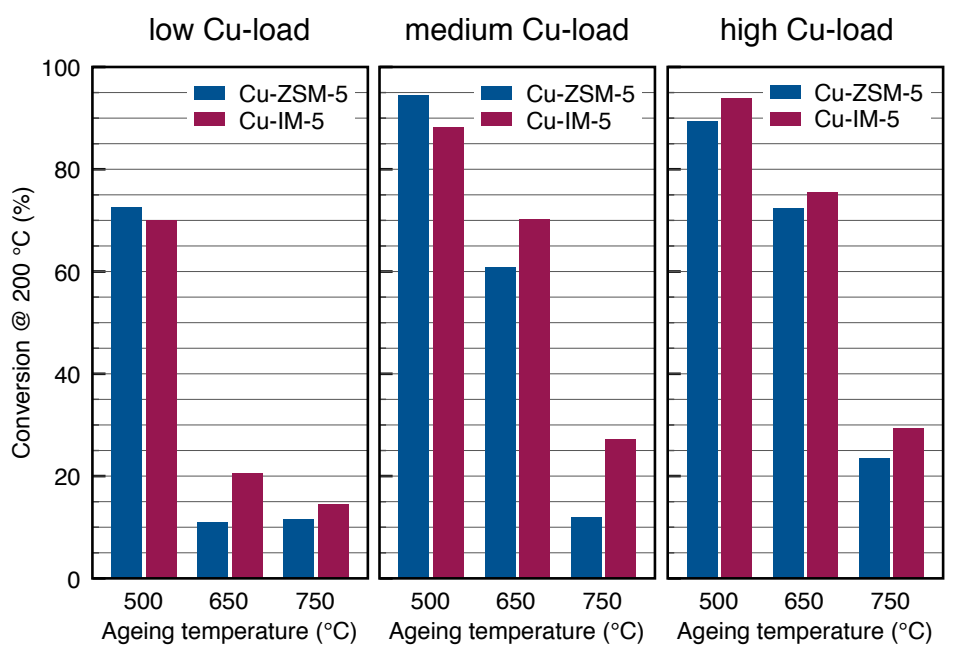

Figure 6.4: $\mathrm{NO}_{\mathrm{x}}$ conversion over $\mathrm{Cu}-\mathrm{ZSM}-5$ and $\mathrm{Cu}-\mathrm{IM}-5$ with various copper loads as given in table 6.1 (low: $\mathrm{Cu} / \mathrm{Al}=0.3$, medium: $\mathrm{Cu} / \mathrm{Al}=0.4$ and high: $\mathrm{Cu} / \mathrm{Al}=0.6$ ) after calcination at $500{ }^{\circ} \mathrm{C}$ and hydrothermal aging at 650 and $750{ }^{\circ} \mathrm{C}$.

From the micropore volumes reported in Table 6.1 only small changes are observed upon aging at $750{ }^{\circ} \mathrm{C}$ in the parent material whereas larger changes are 
seen when copper is present. As copper ions already take up part of the void volume in the zeolite before aging the larger decrease in micropore volume occurs by destruction of the framework by particle growth inside the framework, filling of the void volume or combinations of both. Whereas destruction by growth only requires migration of copper species, it should be noted that filling of the pore volume would require additional material, which should come from the framework e.g. by dealumination. An important conclusion from the change in micropore volume is that the changes in micropore volume does not correlate with the loss of catalytic performance. Instead the changes in micropore volume is better reflected in the loss of crystallinity, which was quantified by integration of several reflections in the x-ray diffractograms of the materials before and after aging (see Figure 6.5).
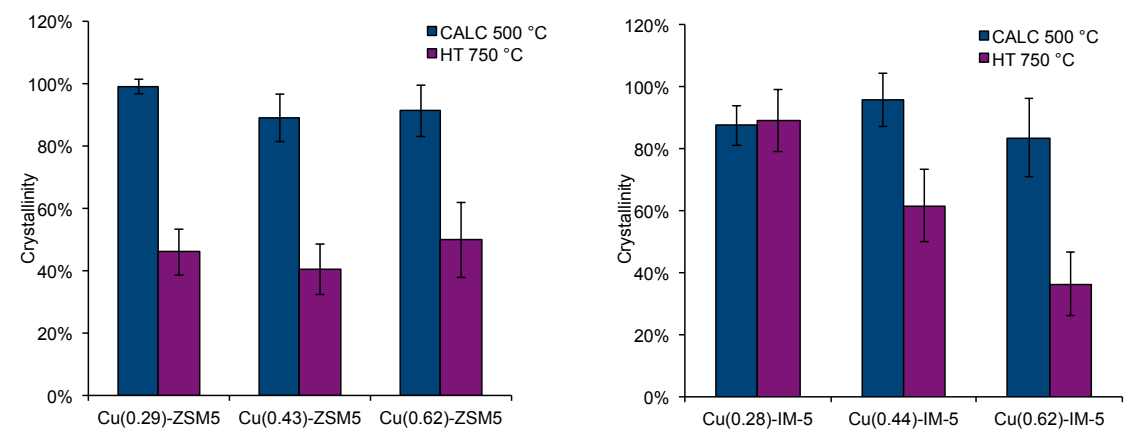

Figure 6.5: Crystallinity of Cu-ZSM-5 (left) and Cu-IM-5 (right) zeolites with various $\mathrm{Cu}$ loads (the $\mathrm{Cu}$ load is given as $\mathrm{Cu} / \mathrm{Al}$ ratio in the parenthesis) after calcination at $500{ }^{\circ} \mathrm{C}$ and after accelerated hydrothermal ageing in at $750{ }^{\circ} \mathrm{C}$.

It is difficult to judge the extent of dealumination based on changes in the textural properties. Instead the acidity imposed by aluminum before and after aging can provide some information. For this purpose the $\mathrm{NH}_{3}$-capacity was used and the changes upon hydrothermal aging is reported in Table 6.2. 
Table 6.2: Acidity of parent H-ZSM-5 and H-IM-5 after calcination at 500 ${ }^{\circ} \mathrm{C}$ and hydrothermal aging at 650 and $750{ }^{\circ} \mathrm{C}$ measured by $\mathrm{NH}_{3}$-TPD. In parenthesis is given the percentage amount of remaining capacity compared to the parent

\begin{tabular}{lccc}
\hline Sample & \multicolumn{3}{c}{$\mathrm{NH}_{3}$ capacity $(\mu \mathrm{mol} / \mathrm{g})$} \\
& $500{ }^{\circ} \mathrm{C}$ & $\mathrm{HT} 650{ }^{\circ} \mathrm{C}$ & $\mathrm{HT} 750{ }^{\circ} \mathrm{C}$ \\
\hline ZSM-5 & 812 & $127(16 \%)$ & $64(8 \%)$ \\
IM-5 & 713 & $185(26 \%)$ & $111(16 \%)$ \\
\hline
\end{tabular}

Based on the $\mathrm{NH}_{3}$-capacity it becomes evident that the extent of dealumination is more severe than the loss of micropore volume and also more severe than the loss in $\mathrm{NO}_{\mathrm{x}}$ conversion where copper is present in the zeolites. This sheds further credibility to the hypothesis that copper ions stabilizes aluminum in the framework. Furthermore the differences between H-ZSM-5 and H-IM-5 is also evident from the $\mathrm{NH}_{3}$-capacity results, where IM-5 is seen to be more stable towards dealumination than H-ZSM-5 as expected and reported earlier.[28, 118] Since $\mathrm{NH}_{3}$ not only adsorbs on the Brønsted acidic protons, but also binds to the $\mathrm{Cu}$ and various $\mathrm{Cu}$-species, a measurement of the $\mathrm{NH}_{3}$-capacity may not be an excellent measure of the acidity imposed only by Al located in framework positions after aging in the $\mathrm{Cu}-\mathrm{ZSM}-5$ and $\mathrm{Cu}-\mathrm{IM}-5$ materials. For this reason it was also chosen to monitor the changes in chemical shift of Al by ${ }^{27}$ Al-MASNMR.

One of the advantages of doing ${ }^{27} \mathrm{Al}-\mathrm{MAS}-\mathrm{NMR}$ spectroscopy is the possibility to distinguish between coordination environments of $\mathrm{Al}$ in zeolites, which will show up as a difference in the chemical shift. For the as-prepared zeolites samples only a single peak located around $50 \mathrm{ppm}$ in the ${ }^{27}$ Al-MAS-NMR spectrum is seen for both Cu-ZSM-5 and Cu-IM-5 with medium copper loads corresponding to aluminum being present in the framework in tetrahedral coordination (Figure 6.6). During dealumination a the occurrence of aluminum in octahedral coordination is expected and would show a peak at a chemical shift of $0 \mathrm{ppm}$. Instead of a simultaneous increase in octahedral coordination, only a decrease in the peak at $50 \mathrm{ppm}$ occurs (Figure 6.6). The decrease is most evident after aging at $750{ }^{\circ} \mathrm{C}$ and somewhat more pronounced for Cu-ZSM-5 compared to $\mathrm{Cu}-\mathrm{IM}-5$. After the aging treatment at $750{ }^{\circ} \mathrm{C}$ only $7 \%$ and $11 \%$ of the signal remains for $\mathrm{Cu}-\mathrm{ZSM}-5$ and $\mathrm{Cu}-\mathrm{IM}-5$ respectively. 


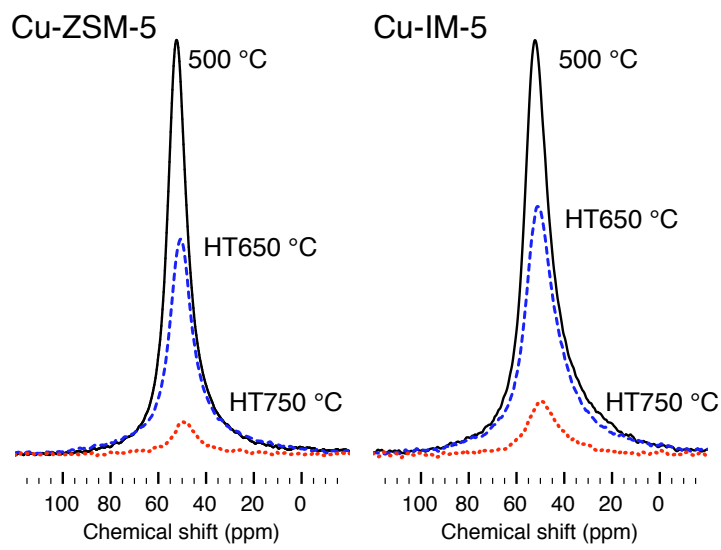

Figure 6.6: ${ }^{27} \mathrm{Al}-\mathrm{MAS}-\mathrm{NMR}$ spectra of Cu-ZSM-5 and Cu-IM-5 after calcination at $500{ }^{\circ} \mathrm{C}$ and hydrothermal aging at 650 and $750{ }^{\circ} \mathrm{C}$

The decrease in the NMR signal without appearance of another signal can be an indication of interaction between $\mathrm{Al}$ and paramagnetic $\mathrm{Cu}^{2+}$. Similar observations of dampening of the NMR signal in deactivated $\mathrm{Cu}$-zeolites have also been observed by other groups.[23, 26, 113, 117] Thus, the dealumination process in $\mathrm{Cu}-\mathrm{ZSM}-5$ and $\mathrm{Cu}-\mathrm{IM}-5$ involves detachment of aluminum from the framework and formation of small aggregates with low symmetry (as bigger particles of e.g. $\mathrm{CuAl}_{2} \mathrm{O}_{4}$ gives an Al-NMR signal) containing paramagnetic copper and aluminum characterized by strong interactions as seen by the decrease in NMR signal.

To follow the changes in copper speciation upon aging in greater detail XAFS was used. Due to the interaction with water under atmospheric conditions it was found that dehydration of the samples is required in order to obtain structural information of copper ions and the zeolite framework. The absorption edge after dehydration is located between 8987 and $8988 \mathrm{eV}$ (determined from half of the edge-step). It is caused by the $1 \mathrm{~s}-4$ p electronic transition of $\mathrm{Cu},[126,127]$ and is characteristic for $\mathrm{Cu}^{2+}$ species (see insert in Figure 6.7). Further corroboration of this assignment is made by the weak, but nevertheless present $1 \mathrm{~s}-3 \mathrm{~d}$ transition at 8976-8977 eV $[128,129]$ marked by the arrow in the first derivative shown in Figure 6.7. Thus, all copper is present as $\mathrm{Cu}^{2+}$ in the samples. 


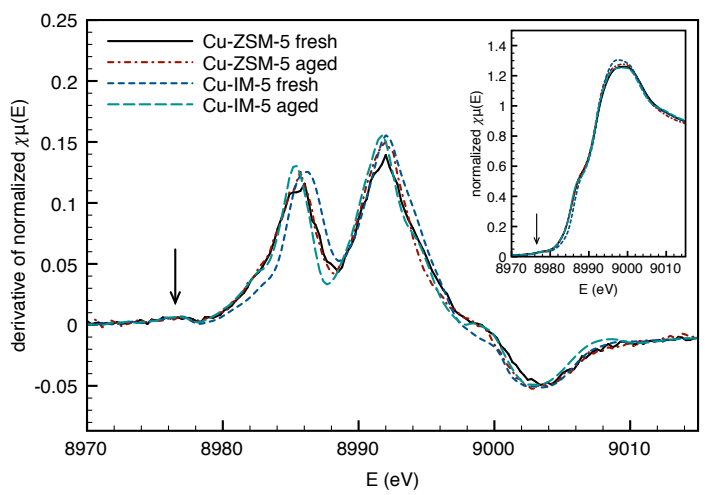

Figure 6.7: XANES spectra (insert) and first derivatives of dehydrated CuZSM-5 and Cu-IM-5 after calcination at $500{ }^{\circ} \mathrm{C}$ and hydrothermal aging at $750{ }^{\circ} \mathrm{C}$

The shoulder in the absorption edge is clearly visible from the two maxima in the derivative shown in Figure 6.7 and correspond to a $1 \mathrm{~s}-4 \mathrm{p}_{\mathrm{xy}}$ shakedown transition as s consequence of distortion of the symmetry.[127] As seen from XANES spectra the features are very similar for the fresh $\mathrm{Cu}$-zeolites and those aged at $750{ }^{\circ} \mathrm{C}$.

More detailed information about the $\mathrm{Cu}$ environment before and after aging is first obtained after making a fit of the amplitude of the Fourier transformed EXAFS (Figure 6.8). Parameters of the fits are summarized in Table 6.3. In the first coordination shell located at a distance of 1.93-1.95 $\AA$ approximately four oxygen atoms are found for all $\mathrm{Cu}$-zeolites. The second shell is however different for the fresh and the samples aged at $750{ }^{\circ} \mathrm{C}$. Attempts to fit the second shell with a single contribution lead to unsatisfactory results in all cases. For this reason two contributions to the second shell were considered and best fits were in all cases obtained with $\mathrm{Cu}-\mathrm{Al}$ coordination at $2.7 \AA$ and $\mathrm{Cu}-\mathrm{Cu}$ coordination at $2.9 \AA$. As can be seen from Figure 6.8 the contribution to the second coordination changes significantly upon aging. The $\mathrm{Cu}-\mathrm{Al}$ coordination number becomes approximately 2, which is consistent with the conclusion that upon aging close contact is made between $\mathrm{Cu}$ and $\mathrm{Al}$, as it was also noted based on the ${ }^{27}$ Al-MAS-NMR results. 
It shall be noted that some uncertainty is inherent in the identity of the atoms used for the fit of the second and higher shells. This is especially true for the third shell located at $3.4 \AA$ in the aged samples. On the other hand, the lack of longer range order in the EXAFS $(>5 \AA)$ confirms that the phase formed upon aging consists of small particles, as extended phases such as $\mathrm{CuO}$ would have shown further coordination shells.
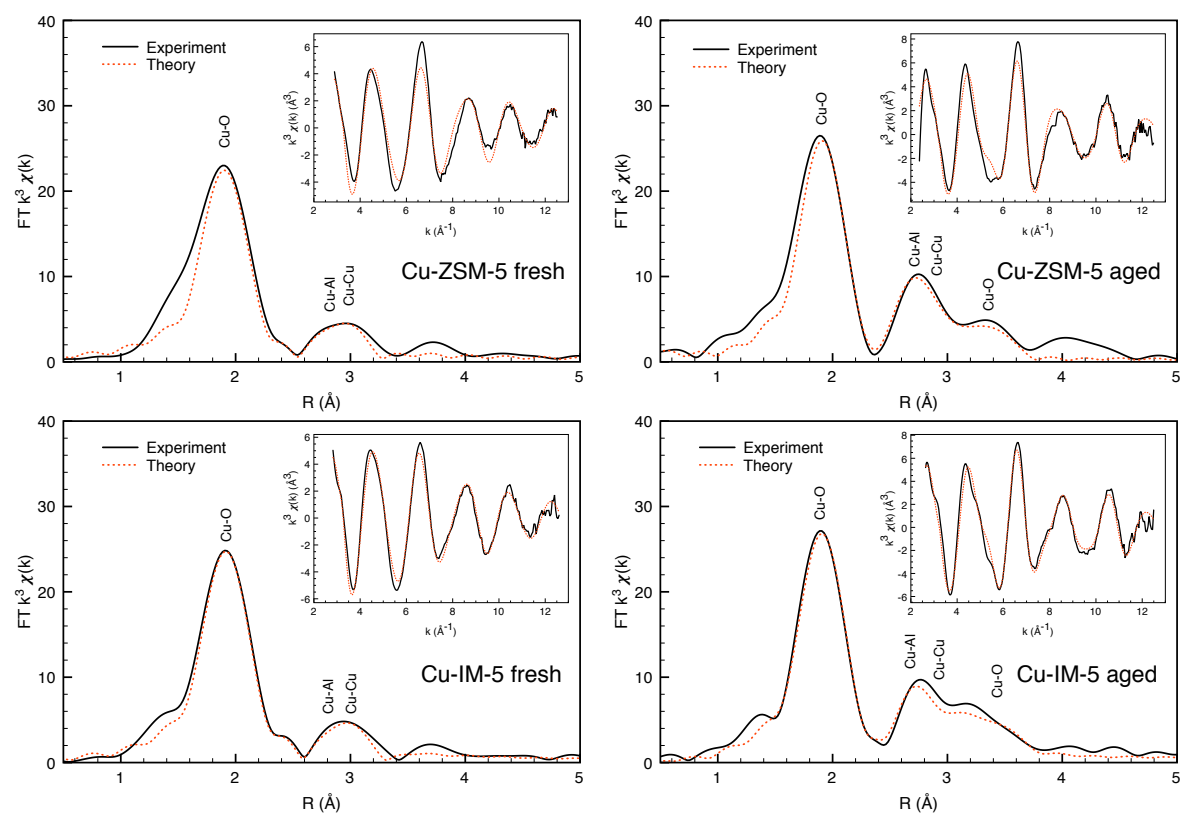

Figure 6.8: FT Magnitude of the EXAFS measured on Cu-zeolites (medium copper load) calcined at $500{ }^{\circ} \mathrm{C}$ and after hydrothermal aging at $750{ }^{\circ} \mathrm{C}$. Inserts show the $\mathrm{k} 3$ weighted EXAFS data in k-space. Experimental data are shown together with the best fitted theoretical model. 
Table 6.3: Results from EXAFS fitting analysis on the dehydrated Cu-ZSM5 and $\mathrm{Cu}-\mathrm{IM}-5$ catalysts after calcination at $500{ }^{\circ} \mathrm{C}$ and hydrothermal aging at $750{ }^{\circ} \mathrm{C}$

\begin{tabular}{|c|c|c|c|}
\hline Coordination & $\mathrm{N}$ & Distance $(\AA)$ & $2 \sigma 2\left(\AA^{2}\right)$ \\
\hline \multicolumn{4}{|c|}{$\mathrm{Cu}-\mathrm{ZSM}-5$ fresh } \\
\hline $\mathrm{Cu}-\mathrm{O}$ & 4.2 & 1.934 & 0.009 \\
\hline $\mathrm{Cu}-\mathrm{Al}$ & 0.7 & 2.692 & 0.009 \\
\hline $\mathrm{Cu}-\mathrm{Cu}$ & 0.4 & 2.933 & 0.009 \\
\hline \multicolumn{4}{|c|}{$\mathrm{Cu}$-ZSM- 5 aged at $750^{\circ} \mathrm{C}$} \\
\hline $\mathrm{Cu}-\mathrm{O}$ & 4.6 & 1.955 & 0.009 \\
\hline $\mathrm{Cu}-\mathrm{Al}$ & 0.7 & 2.701 & 0.009 \\
\hline $\mathrm{Cu}-\mathrm{Cu}$ & 0.5 & 2.925 & 0.009 \\
\hline $\mathrm{Cu}-\mathrm{O}$ & 2.8 & 3.379 & 0.009 \\
\hline \multicolumn{4}{|c|}{ Cu-IM-5 fresh } \\
\hline $\mathrm{Cu}-\mathrm{O}$ & 4.1 & 1.946 & 0.011 \\
\hline $\mathrm{Cu}-\mathrm{Al}$ & 0.7 & 2.746 & 0.011 \\
\hline $\mathrm{Cu}-\mathrm{Cu}$ & 0.3 & 2.983 & 0.011 \\
\hline \multicolumn{4}{|c|}{$\mathrm{Cu}-\mathrm{IM}-5$ aged at $750^{\circ} \mathrm{C}$} \\
\hline $\mathrm{Cu}-\mathrm{O}$ & 4.1 & 1.941 & 0.010 \\
\hline $\mathrm{Cu}-\mathrm{Al}$ & 1.9 & 2.717 & 0.010 \\
\hline $\mathrm{Cu}-\mathrm{Cu}$ & 0.4 & 2.997 & 0.010 \\
\hline $\mathrm{Cu}-\mathrm{O}$ & 3.0 & 3.402 & 0.010 \\
\hline
\end{tabular}

Dealumination and changes in copper imposed by the hydrothermal aging were also followed by the $\mathrm{OH}$-vibrations between 3400 and $3800 \mathrm{~cm}^{-1}$ via infrared spectroscopy. Three distinct features are observed in the $\mathrm{Cu}$-zeolites calcined at $500{ }^{\circ} \mathrm{C}$. The first features appear in the range of $3700-3750 \mathrm{~cm}^{-1}$, and is associated with two types of silanol groups. The band located $3740 \mathrm{~cm}^{-1}$ corresponds to isolated silanols $(\mathrm{Si}-\mathrm{OH})$ on the external surface, $[130,131]$ while isolated internal silanol groups are seen as a shoulder around $3720 \mathrm{~cm}^{-1}$.[132] The second feature is the band located at $3610 \mathrm{~cm}^{-1}$, which is routinely assigned to Brønsted acid sites related to bridging hydroxyl groups ( $\mathrm{Si}-(\mathrm{OH})-\mathrm{Al})$. The third feature is a band at $3668 \mathrm{~cm}^{-1}$. The assignment of this band is not straightforward. It has earlier been assigned to partial extra-framework aluminum, $[128,133]$ but it should be noted that from the NMR results no Al in octahedral coordination were observed. Another assignment suggested recently is to the hydroxide group on a single $\mathrm{Cu}^{2+}$ ion (i.e. [Cu-OH]).[48]

Upon hydrothermal aging at $650{ }^{\circ} \mathrm{C}$ many of the Brønsted acid sites are consumed and only a small fraction remain after hydrothermal aging at $750{ }^{\circ} \mathrm{C}$. 
This points towards removal of $\mathrm{Al}$ from the framework in both $\mathrm{Cu}-\mathrm{IM}-5$ and $\mathrm{Cu}$-ZSM-5, as was also observed using ${ }^{27} \mathrm{Al}-\mathrm{MAS}-\mathrm{NMR}$. The band from either partial extra-framework aluminum or copper hydroxyl groups appear to increase after the intermediate hydrothermal aging, but is also consumed after the 750 ${ }^{\circ} \mathrm{C}$ hydrothermal treatment. Assuming that there is only little or no partial extra-framework aluminum in the fresh samples and that extra $\mathrm{Cu}-\mathrm{OH}$ species are not generated; the OH-region suggests accordingly that aluminum is partially detached from the framework upon the intermediate aging, and that both $\mathrm{Cu}-\mathrm{OH}$ and $\mathrm{OH}$-sites associated with $\mathrm{Al}$ is consumed during the $750{ }^{\circ} \mathrm{C}$ aging procedure.

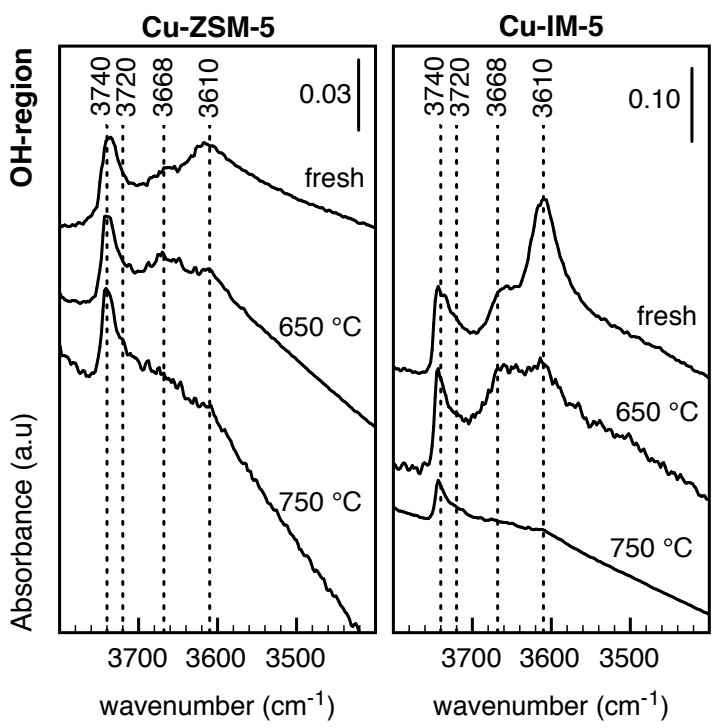

Figure 6.9: IR spectra in the $\nu \mathrm{OH}$ region of the $\mathrm{Cu}-\mathrm{ZSM}-5$ and $\mathrm{Cu}-\mathrm{IM}-5$ (medium copper load) before after calcination at $500{ }^{\circ} \mathrm{C}$ and after hydrothermal aging at 650 and $750{ }^{\circ} \mathrm{C}$ 

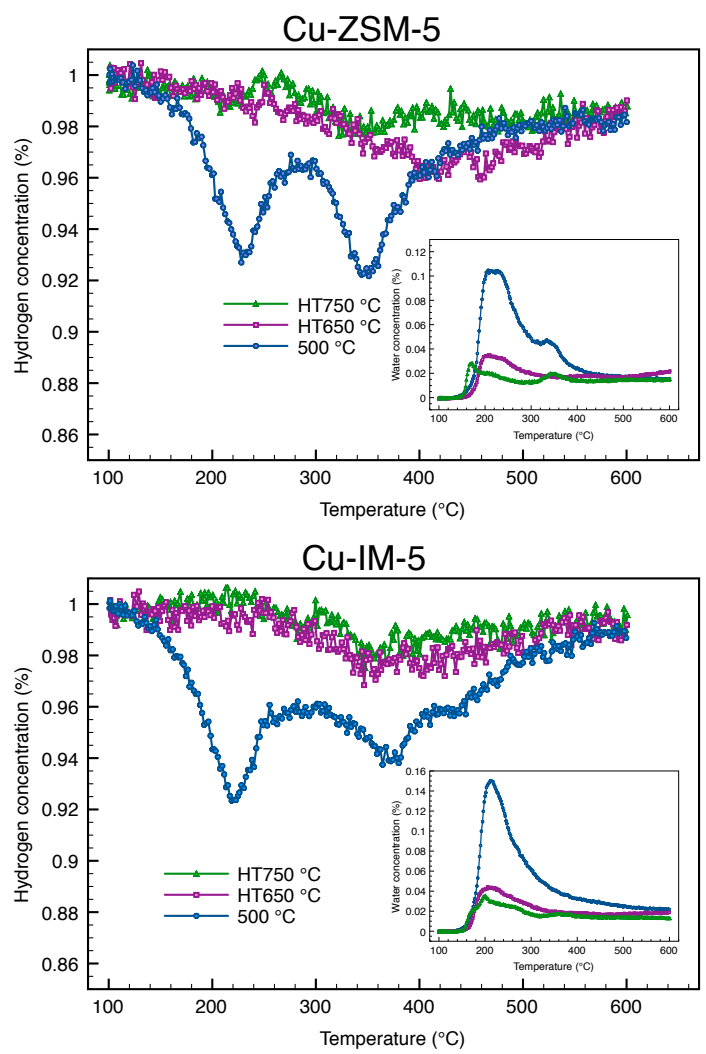

Figure 6.10: $\mathrm{H}_{2}$ signal during temperature programmed reduction of $\mathrm{Cu}-$ ZSM-5 and Cu-IM-5 (medium copper loads) after calcination at $500{ }^{\circ} \mathrm{C}$ and hydrothermal aging at 650 and $750{ }^{\circ} \mathrm{C}$. The insert shows the $\mathrm{H}_{2} \mathrm{O}$ evolution during reduction

The reducibility of the copper species in ZSM-5 and IM-5 was also studied by $\mathrm{H}_{2}$-TPR using $1 \% \mathrm{H}_{2}$ (Figure 6.10). In the fresh Cu-ZSM-5 and Cu-IM-5 two hydrogen consumption peaks are seen around $220{ }^{\circ} \mathrm{C}$ and $350{ }^{\circ} \mathrm{C}$. These correspond to consecutive reactions from $\mathrm{Cu}^{2+}$ to $\mathrm{Cu}^{+}$and then further from $\mathrm{Cu}^{+}$ to $\mathrm{Cu}^{0}$.[134] Integration of the $\mathrm{H}_{2}$ consumption give 0.89 and $0.98 \mathrm{H}_{2}$ molecules per $\mathrm{Cu}$-atom in $\mathrm{Cu}-\mathrm{ZSM}-5$ and $\mathrm{Cu}-\mathrm{IM}-5$, respectively, and in good agreement with a full reduction of all the copper except for a small fraction that has most 
likely undergone self-reduction.[120] Furthermore the $\mathrm{H}_{2} \mathrm{O}$ signal was monitored during the reduction. Most relevant for this study is the production of $\mathrm{H}_{2} \mathrm{O}$ (inserts of Figure 6.10) in the second reduction step. This is a good indication of some dimer formation, as only the reduction of dimers leads to a release of $\mathrm{H}_{2} \mathrm{O}$ in the second reduction step where copper is reduced from oxidation state I to 0.[135] Integration of this signal gives a release of $\mathrm{H}_{2} \mathrm{O}$ per $\mathrm{Cu}$-atom of 0.39 and 0.40 during the second part of the reduction and in good agreement with the amount of $\mathrm{Cu}-\mathrm{Cu}$ coordination found by EXAFS.

After hydrothermal aging at 650 and $750{ }^{\circ} \mathrm{C} \mathrm{Cu}$-ZSM-5 and Cu-IM-5 consume $\mathrm{H}_{2}$ in an almost similar manner and the consumption is seen as a single broad feature, which is shifted to higher temperatures. Adding to this, by integration the $\mathrm{H}_{2}$ consumption does not correspond to all the copper either. The absence of hydrogen consumption below $300{ }^{\circ} \mathrm{C}$ furthermore indicates that $\mathrm{Cu}$ is not transformed to $\mathrm{Cu}_{2} \mathrm{O}$ or $\mathrm{CuO}$, which would show reduction in this temperature range.[136, 137] Together with the close proximity of $\mathrm{Cu}$ and $\mathrm{Al}$ after hydrothermal aging suggested by ${ }^{27} \mathrm{Al}-\mathrm{MAS}-\mathrm{NMR}$, and the difficulty to reduce the formed phase; this points to the formation of copper-aluminate-like species as these are more difficult to reduce and would require higher temperatures.[138]

The catalytic performance of H-zeolite, $\mathrm{CuO}, \mathrm{CuO}$ mixed with $\mathrm{H}-\mathrm{ZSM}-5$ and $\mathrm{CuAl}_{2} \mathrm{O}_{4}$ mixed with $\mathrm{H}-\mathrm{ZSM}-5$ was examined in the $\mathrm{NH}_{3}-\mathrm{SCR}$ reaction under similar conditions as the Cu-zeolites (Figure 6.11). Pure H-ZSM-5, CuO and the mixture of $\mathrm{CuAl}_{2} \mathrm{O}_{4}$ and $\mathrm{H}-\mathrm{ZSM}-5$ display no significant NO conversion below $300{ }^{\circ} \mathrm{C}$. Above this temperature pure $\mathrm{CuO}$ begin to oxidize $\mathrm{NH}_{3}$ to $\mathrm{NO}$, the mixture of $\mathrm{CuAl}_{2} \mathrm{O}_{4}$ and H-ZSM-5 begin to reduce some of the $\mathrm{NO}$ with $\mathrm{NH}_{3}$ and only very little $\mathrm{NO}$ is converted over the $\mathrm{H}$-form zeolite.

Only when $\mathrm{CuO}$ is mixed with $\mathrm{H}-\mathrm{ZSM}-5$ conversion of $\mathrm{NO}$ is accomplished below $300{ }^{\circ} \mathrm{C}$. In fact, $\mathrm{NO}_{\mathrm{x}}$ and $\mathrm{NH}_{3}$ conversion together with the $\mathrm{N}_{2} \mathrm{O}$ production is identical to what was observed for that of the aqueous copper exchanged zeolites. For comparison the performance of a copper exchanged Cu-ZSM-5 has also been included in Figure 6.11. As a result of the similarity it was concluded that the pretreatment for $1 \mathrm{~h}$ under reaction conditions at $550{ }^{\circ} \mathrm{C}$ is sufficient to exchange the $\mathrm{H}$-form of the zeolite with SCR active copper species in a solid state ion exchange process (SSIE).[139] 

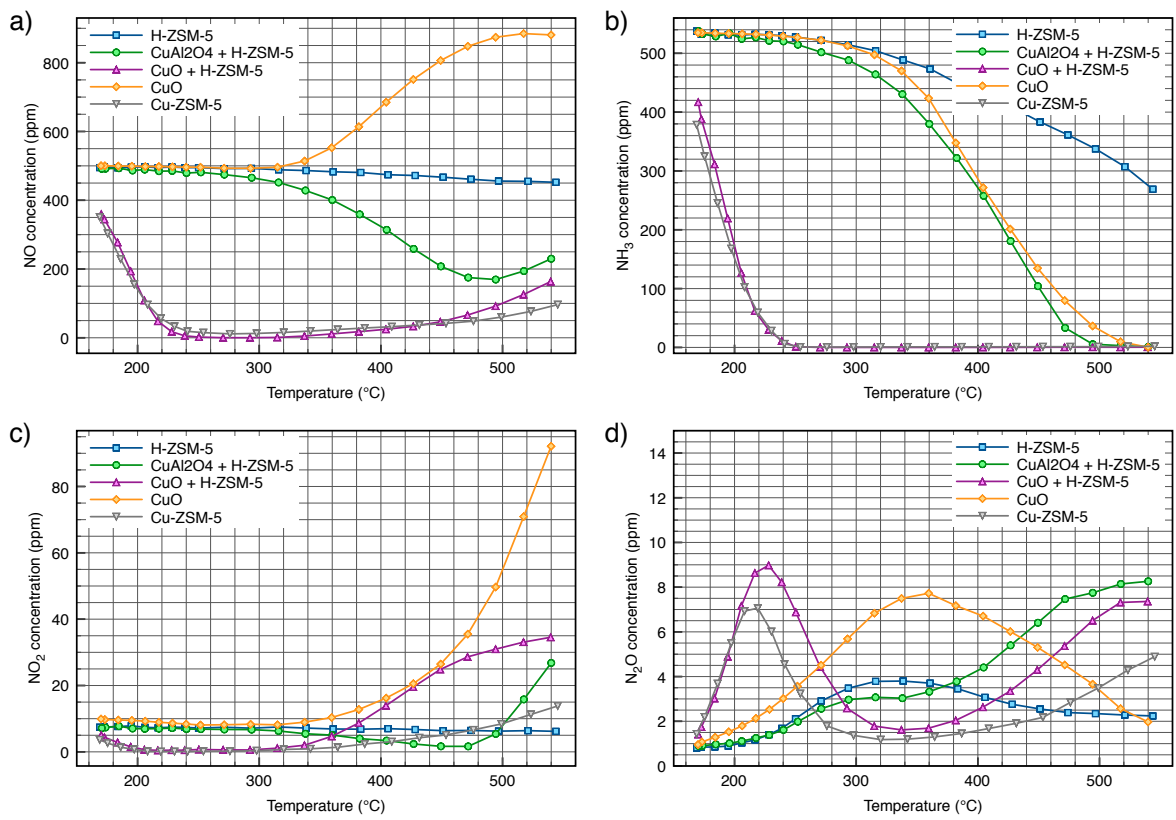

Figure 6.11: Catalytic performance of reference materials as a function of temperature. In a) $\mathrm{NO}$ concentration, b) $\mathrm{NH}_{3}$ concentration, c) $\mathrm{NO}_{2}$ concentration and d) $\mathrm{N}_{2} \mathrm{O}$ production. Reference materials were $\mathrm{H}-\mathrm{ZSM}-5,20$ wt.\% $\mathrm{CuAl}_{2} \mathrm{O}_{4}+\mathrm{H}-\mathrm{ZSM}-5,20$ wt.\% CuO, pure CuO (8 mg) and Cu-ZSM-5 (ion exchanged with $\mathrm{Cu} / \mathrm{Al}=0.29$ )

In order to further investigate the SSIE process, TEM microscopy was used in combination with EDS analysis to monitor the migration of copper ions from $\mathrm{CuO}$ and into H-ZSM-5 crystals. Representative zeolite crystals were found in the physical mixture before and after exposure to an SCR gas at $550{ }^{\circ} \mathrm{C}$ and EDS spectra were measured. An example of one crystal with the corresponding EDS spectrum before and after exposure to the SCR gas mixture is shown in Figure $6.12 \mathrm{a}$ and $\mathrm{b}$ respectively. 

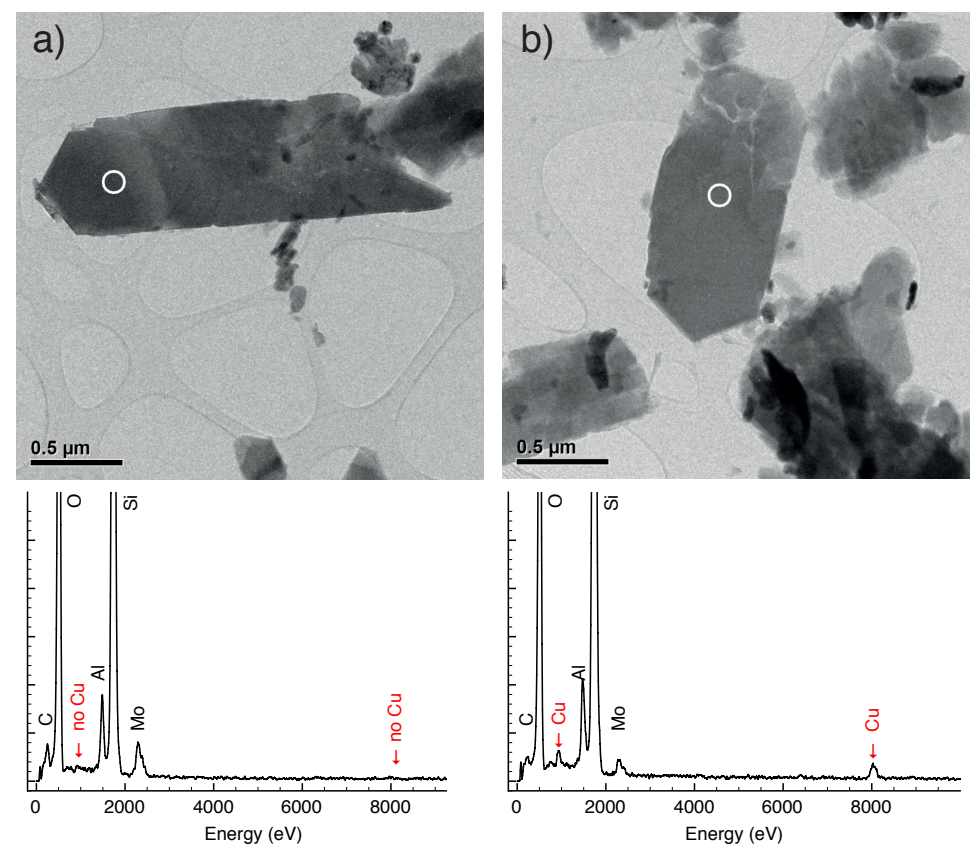

Figure 6.12: Representative TEM images of zeolite crystals in the physical mixture of $\mathrm{CuO}$ and $\mathrm{H}-\mathrm{ZSM}-5$ a) before and b) after exposure to an SCR gas composition at $550{ }^{\circ} \mathrm{C}$ for $1 \mathrm{~h}$ together with corresponding EDS spectra measured in the indicated area. Note that characteristic X-rays from Mo and $\mathrm{C}$ are also seen in the spectra due to the sample grid

The migration of copper ions from $\mathrm{CuO}$ particles and into ion exchange positions under typical SCR conditions is unambiguously confirmed by the comparison of the EDS spectra shown in Figure 6.12a and b as well as EDS spectra measured on several particles in Figure 6.13. Before being exposed to the SCR-reaction no detectable quantities of $\mathrm{Cu}$ could be observed inside the zeolite crystals. However, after exposure to the SCR gas composition for one hour at $550{ }^{\circ} \mathrm{C}$, the EDS spectrum clearly show the presence of $\mathrm{Cu}$ in the crystal as evidenced by the characteristic X-ray peaks for $\mathrm{Cu} \mathrm{K} \alpha$ and $\mathrm{L} \alpha$ at 8.04 and $0.93 \mathrm{keV}$. 
a)

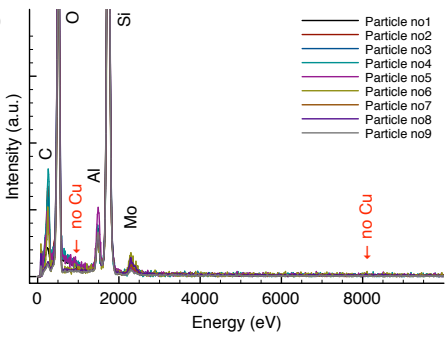

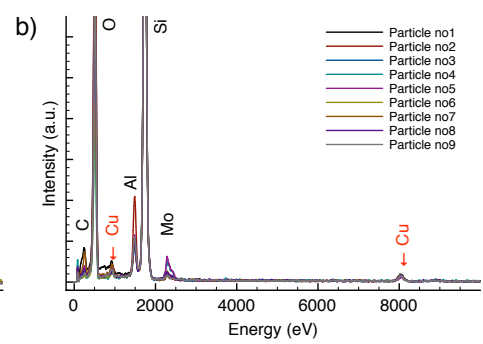

Figure 6.13: EDS spectra measured on several zeolite particles a) before and b) after exposure to an SCR gas composition at $550{ }^{\circ} \mathrm{C}$ for $1 \mathrm{~h}$.

Figure 6.14 schematically summarizes the main conclusions reached in the above characterization and catalytic studies and suggests a tentative mechanism for deactivation of $\mathrm{Cu}-\mathrm{ZSM}-5$ and $\mathrm{Cu}-\mathrm{IM}-5$.

It should be noted that the catalytic activity correlates well with the loss of ${ }^{27} \mathrm{Al}-$ MAS-NMR signal, and therefore gives a measure of the irreversible formation of the inactive $\mathrm{Cu}-\mathrm{Al}$ phase. As the loss in $\mathrm{H}_{2}$ consumption in the TPR experiment did not correlate with the SCR activity loss or loss of NMR signal, it was concluded that partial detachment of aluminum from the framework leads to tenacity towards reduction, but that the active copper sites can be regenerated under the $\mathrm{NH}_{3}$-SCR conditions used in the pretreatment. Thus reaction a) in Figure 6.14 should be considered reversible. Reaction b) represent the possible migration of copper species to form $\mathrm{CuO}$, which is also a reversible reaction, if the framework acidity is maintained as suggested by the catalytic testing of a mixture of $\mathrm{CuO}$ and protonic ZSM-5 shown above. Oppositely the formation of the $\mathrm{Cu}-\mathrm{Al}$ appear to be irreversible and does not contribute substantially to the SCR activity at low temperatures $\left(<300{ }^{\circ} \mathrm{C}\right)$. Moreover, as no octahedrally coordinated aluminum was observed by NMR the copper species act as scavengers to form the $\mathrm{Cu}-\mathrm{Al}$ phase once the aluminum is detached from the framework. This is shown by reaction c) and d) in Figure 6.14. The proposed hydrothermal deactivation mechanism for Cu-ZSM-5 and Cu-IM-5 shown in Figure 6.14 is different to that proposed by Brandenberger et al. for Fe-zeolites,[112] as the deactivation of $\mathrm{Cu}$-zeolite depends on the stability of the zeolite framework, whereas for Fe-zeolites, the deactivation depends on the stability of the iron species themselves. Because of the resemblance between copper aluminate and the formed $\mathrm{Cu}-\mathrm{Al}$ phase after hydrothermal aging the difference between $\mathrm{Cu}$ - and Fe-zeolite hydrothermal deactivation should be understood through 
a)

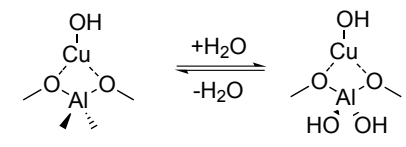

b)

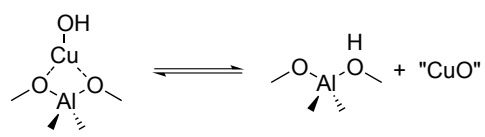

c)

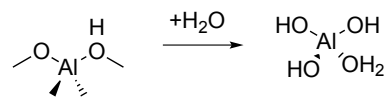

d)

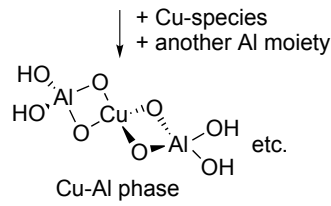

Figure 6.14: Proposed hydrothermal deactivation scheme of Cu-ZSM-5 and $\mathrm{Cu}-\mathrm{IM}-5$. In reaction a) and b) the initial site represent ion exchanged copper sites and can have various identities

the respective spinel and oxide stabilities. Phase equilibria of Fe-Al-O[140] and $\mathrm{Cu}-\mathrm{Al}-\mathrm{O}[141]$ systems have earlier been studied and while the aluminate spinel with copper forms readily under hydrothermal conditions similar to the ones in this study, iron aluminate does not. For this reason only the oxide forms of iron are relevant and therefore the deactivation of Fe-zeolites is less influence by the framework stability of the zeolite as compared to their $\mathrm{Cu}$-equivalents.

\subsection{Summary and Conclusions}

Cu-IM-5 and Cu-ZSM-5 were synthesized with different copper loads and used for comparison of the influence of framework aluminum stability on hydrothermal deactivation. Both showed very similar fresh $\mathrm{NH}_{3}-\mathrm{SCR}$ activities Upon hydrothermal aging the higher framework stability of IM-5 resulted in a better preservation of the catalytic performance. Simultaneously a stabilizing effect of exchanged copper on framework aluminum-sites was also observed based on comparison of the loss of activity of the $\mathrm{Cu}$-zeolites versus the loss of acidity in the parent materials. 
From characterization of the copper species by XANES the $\mathrm{Cu}$ was shown to be present in the +2 state both before and after hydrothermal aging. As a consequence of the aging $\mathrm{Cu}$ was shown to to interact strongly with fully detached $\mathrm{Al}$ leading to a decrease in the ${ }^{27} \mathrm{Al}-\mathrm{MAS}-\mathrm{NMR}$ signal from tetrahedrally coordinated aluminum after aging. This was assigned to an irreversible formation of a $\mathrm{Cu}-\mathrm{Al}$ phase, and also confirmed by EXAFS analysis. Furthermore from the shoulder in the XANES Cu-edge a tetragonal distortion of the $\mathrm{Cu}$ symmetry was evident. This is different from the copper coordination in $\mathrm{CuAl}_{2} \mathrm{O}_{4}$ and could be a consequence of small particle sizes. On the other hand it was difficult to reduce the formed $\mathrm{Cu}-\mathrm{Al}$ phase and thus some similarity to $\mathrm{CuAl}_{2} \mathrm{O}_{4}$ exists. Catalytic activity tests of physical mixtures of various copper containing phases and H-ZSM-5 furthermore revealed that copper ions can migrate into ion exchange positions from a $\mathrm{CuO}$ phase under reaction conditions, which was confirmed by TEM/EDS analysis.

Based on the findings a deactivation scheme was proposed for $\mathrm{Cu}-\mathrm{IM}-5$ and $\mathrm{Cu}$-ZSM-5, where the framework stability dictates the overall stability. This finding is different than the mechanism proposed for Fe-zeolites, which can be understood in terms of the ability to form aluminate spinel structures. 


\section{Summary, Conclusions and Perspectives}

\subsection{Summary and Conclusions}

Selective catalytic reduction of nitrogen oxides with ammonia $\left(\mathrm{NH}_{3}-\mathrm{SCR}\right.$ of $\mathrm{NO}_{\mathrm{x}}$ ) using copper exchanged zeolite catalysts was investigated in this thesis. A motivation for the removal of $\mathrm{NO}_{\mathrm{x}}$, inevitably formed during high temperature combustion processes, was provided in Chapter 1 based on environmental and human health related consequences. Special attention was devoted to emission standards for diesel vehicles where legislation only recently has become so stringent that catalytic solutions are required. The industrial scene was described by showing a typical exhaust after-treatment system including an SCR catalyst to meet future EURO VI standards. In such a system the SCR catalyst requires high activity and high hydrothermal stability as illustrated by $\mathrm{NO}_{\mathrm{x}}$ and temperature fluctuations measured in engine test and during active regenerations of a diesel particulate filter. One of the most promising solutions to meet activity and stability requirements is by the use of metal exchanged zeolites and in particular copper exchanged zeolites, which has been the subject of study in this thesis.

In Chapter 2 eight different zeolite framework topologies: BEA, FAU, MOR, 
MFI, SZR, CHA, FER and LEV were compared in the $\mathrm{NH}_{3}$-SCR reaction where $\mathrm{NO}_{\mathrm{x}}$ conversion between 170 and $500{ }^{\circ} \mathrm{C}$ was measured. Each zeolite was prepared with similar aluminum contents and copper loads to make the best comparison. Based on the $\mathrm{NO}_{\mathrm{x}}$ conversion in the low temperature regime (170 and $250{ }^{\circ} \mathrm{C}$ ) the most promising zeolite topologies for $\mathrm{NH}_{3}$-SCR purposes were BEA, MFI and CHA all having three-dimensional pore systems. These three topologies showed significantly better performance than all other tested topologies. From the catalytic testing it was concluded that the highest observed activity could be obtained over zeolites with three-dimensional pore systems with similar window sizes in all three dimensions. The $\mathrm{NH}_{3}$-SCR performance of all catalysts was also tested after exposure to hydrothermal aging conditions and showed that zeolites with smaller pores had an increased catalyst stability (except in the the case of the $\mathrm{Cu}-\mathrm{BEA}$ system that showed medium stability despite having large pores). Finally, the $\mathrm{N}_{2} \mathrm{O}$ selectivity in the $\mathrm{NH}_{3}-\mathrm{SCR}$ reaction, which will be regulated in future emission standards, was shown to depend on the window size and channel dimensionality in the zeolite structures. Altogether, these observations allows for a set of guidelines in the search for novel zeolite framework topologies for the use as $\mathrm{NH}_{3}$-SCR catalysts.

Unburnt hydrocarbons (HCs) could constitute a problem in the use of copper exchanged zeolites in automotive applications due to the poisoning of the catalytically active sites. Therefore the influence of $n$-decane and propylene was investigated in Chapter 3. Three copper exchanged zeolite topologies were tested: $\mathrm{Cu}-\mathrm{BEA}, \mathrm{Cu}-\mathrm{MFI}$ and $\mathrm{Cu}-\mathrm{CHA}$ that has 12-,10-, and 8-member ring window sizes respectively. The effect of $n$-decane as well as propylene at $300{ }^{\circ} \mathrm{C}$ was found to largely depend on the window size. Cu-BEA was more affected than $\mathrm{Cu}-\mathrm{MFI}$, and $\mathrm{Cu}-\mathrm{CHA}$ did not show any poisoning under the applied conditions during $n$-decane exposure. Propylene was however able to enter the pore system of CHA and therefore it was chosen for further studies of the influence of framework polarity on HC poisoning. Small-pore zeolite Cu-SSZ-13 and $\mathrm{Cu}-\mathrm{SAPO}-34$; both with the CHA topology, but different polarity were used in this case. Using these two catalysts it was shown that the $\mathrm{NH}_{3}-\mathrm{SCR}$ catalytic performance of $\mathrm{Cu}-\mathrm{SSZ}-13$ is more influenced by the presence propylene than $\mathrm{Cu}-\mathrm{SAPO}-34$ at higher temperatures $\left(>250{ }^{\circ} \mathrm{C}\right)$. In addition to the above findings, it was in all cases found that catalyst activity could be recovered when the $\mathrm{Cu}$-zeolites were heated to $550{ }^{\circ} \mathrm{C}$. Thus, for practical applications poisoning from $\mathrm{HCs}$ can be minimized by occasionally raising the temperature of the catalyst. 
As a consequence of the promising results obtained on small-pore zeolite $\mathrm{Cu}$ SSZ-13 and silicoaluminophosphate Cu-SAPO-34, as well as their reported high hydrothermal stability, further attention was devoted to these two catalysts in Chapter 4 and 5. It was shown that aqueous ion exchange does not lead to a homogenous distribution of copper in SAPO-34. Instead the copper becomes located close to the external surface after exchange from where it imposes severe diffusion limitations on the catalytic performance. Thermal treatments (optimal temperature was found to be $750{ }^{\circ} \mathrm{C}$ ) was shown to be efficient in redistributing the copper, which lead to several fold increase in $\mathrm{NH}_{3}$-SCR catalytic activity. In comparison a homogenous distribution of copper was obtained in exchanged $\mathrm{Cu}-\mathrm{SSZ}-13$ and thermal treatments did not lead to significant improvements of catalytic activity for this material. The described increase in catalytic activity makes $\mathrm{Cu}-\mathrm{SAPO}-34$ a promising catalyst for industrial applications since it displays TOFs even higher than $\mathrm{Cu}-\mathrm{SSZ}-13$.

The thermal activations were further explored in Chapter 5 where DFT calculations were used to investigate the mechanism of copper migration. The findings suggested that the limiting step in the migration of copper is closely related the migration of charge compensating protons. Based on these findings, improvements to the atmosphere composition during activation of $\mathrm{Cu}-\mathrm{SAPO}-34$ were made. These included thermal activation in a wet atmosphere. In supplement to the theoretical considerations, Cu-SAPO-34 was activated under wet conditions experimentally at $750{ }^{\circ} \mathrm{C}$. After such activation further $20-31 \%$ increase in activity was observed at $180^{\circ} \mathrm{C}$, which support the conclusions from the DFT calculations.

In Chapter 6 the hydrothermal deactivation mechanism of $\mathrm{Cu}$-zeolites was investigated using $\mathrm{Cu}-\mathrm{ZSM}-5$ and $\mathrm{Cu}-\mathrm{IM}-5$. The frameworks were chosen so that they have very similar architectural features, but slightly different susceptibilities towards dealumination. The deactivation was followed after hydrothermal aging at two different temperatures by catalytic testing showing that Cu-IM-5 maintained a higher activity than Cu-ZSM-5. From comparison of the catalytic performance and characterization of fresh and hydrothermally aged samples, it was possible to propose a deactivation scheme. The changes in catalyst structure that occur during aging were found to be i) partial dealumination of the zeolite, ii) reversible migration of copper species, and iii) irreversible formation of catalytically inactive and stable $\mathrm{Cu}$-Al clusters, which have some resemblance to $\mathrm{CuAl}_{2} \mathrm{O}_{4}$, but without the symmetry of $\mathrm{Cu}$ in this spinel structure. As the $\mathrm{Cu}-\mathrm{Al}$ clusters only form once $\mathrm{Al}$ is detached from the framework, the stability of $\mathrm{Al}$ in the zeolite framework was proposed to dictate the overall hydrothermal 
deactivation behavior of $\mathrm{Cu}-\mathrm{ZSM}-5$ and $\mathrm{Cu}-\mathrm{IM}-5$ in the $\mathrm{NH}_{3}-\mathrm{SCR}$ reaction.

\subsection{Perspectives}

With the increasingly more stringent legislation the need to improve zeolite $\mathrm{NH}_{3}$-SCR catalytic performance and stability in particular has driven research within this field fast forward in recent years. This is from a materials perspective perhaps most clearly seen in the development of $\mathrm{Cu}-\mathrm{CHA}$ catalysts, which offer high stability and a simple model to study in greater detail the mechanism of SCR over zeolites. In this context, it should be mentioned that a full understanding of the catalytic activity and deactivation mechanisms have not yet been obtained. Such an understanding requires a full understanding of location and identity of copper species inside the microporous interior of zeolites as well as a full description of the re-oxidation of copper sites. This is the prerequisite for a leap in future development of $\mathrm{Cu}$-zeolites for SCR applications. One of the main findings in this thesis is that copper ions are relatively mobile inside zeolites and that different species prevail at different conditions relevant for SCR applications. Thus, it is likely that a full mechanistic description should include very dynamic changes in speciation and location of copper species. It might even be that different species can lead to two different mechanisms that dominate at different temperatures, or even different conditions. These are the questions that need answering in future investigations.

On the legislation side; absolute $\mathrm{NO}_{\mathrm{x}}$ reduction numbers has most likely reached the lower limit in western countries. Subsequent actions will therefore be concerned about the identity of the $\mathrm{NO}_{\mathrm{x}}$ emitted. Especially $\mathrm{N}_{2} \mathrm{O}$ will be controlled in a stricter manner and actions are already underway. To accommodate this a better, and hopefully mechanistic, understanding of the unwanted side reactions should also be sought. Although it has not been explained in this thesis how the $\mathrm{N}_{2} \mathrm{O}$ is created, it has empirically been shown that the selectivity towards it depends on the pore size and dimensionality. This provides one certain descriptor in the rationalized search for novel zeolites framework topologies that will be key in future catalytic systems for environmental applications. In addition to selectivity issues, future legislation are going to target fuel economy, which would inevitably result in colder exhaust temperatures. This would make the copper exchanged zeolites even more relevant due to their excellent low-temperature performance. 


\section{Bibliography}

[1] WHO Air quality guidelines - global update 2005.

http://whqlibdoc.who.int/hq/2006/WHO_SDE_PHE_OEH_06.02_eng.pdf (2006).

[2] U.S. Environmental Protection Agency, United States Environmental Protection Agency, http://www.epa.gov/air/nitrogenoxides/ (2013).

[3] G. Likens, R. Wright, J. Galloway, T. Butler, Sci. Am. 241, 43 (1979).

[4] D. Fowler, C. Flechard, U. Skiba, M. Coyle, J. N. Cape, New Phytol. 139, 11 (1998).

[5] DieselNet, Emission Standards, http://dieselnet.com/standards/ (2013).

[6] Clean Air Act Extension of 1970, 84 Stat. 1676, P.L. 91-604, 1970-12-31. (1970).

[7] R. W. Broach, et al., Ullmann's Encyclopedia of Industrial Chemistry (Wiley-VCH Verlag GmbH \& Co. KGaA, Weinheim, Germany, 2012), chap. Zeolites, pp. 1-35.

[8] J. Čejka, D. Kubička, Kirk-Othmer Encyclopedia of Chemical Technology, no. 9 (John Wiley \& Sons, Inc., Hoboken, NJ, USA, 2010), pp. 1-30. 
[9] C. Baerlocher, L. B. McCusker, IZA Database of Zeolite Structures (2013).

[10] S. Brandenberger, O. Kröcher, A. Tissler, R. Althoff, Catal. Rev. Sci. Eng. 50, 492 (2008).

[11] F. Gao, J. H. Kwak, J. Szanyi, C. H. F. Peden, Top. Catal. 56, 1441 (2013).

[12] M. Devadas, et al., Appl. Catal., B 67, 187 (2006).

[13] R. Long, J. Catal. 207, 224 (2002).

[14] M. P. Ruggeri, I. Nova, E. Tronconi, Top. Catal. 56, 109 (2013).

[15] V. F. Kispersky, a. J. Kropf, F. H. Ribeiro, J. T. Miller, PCCP 14, 2229 (2012).

[16] W. Williamson, J. Lunsford, J. Phys. Chem. 2312, 2664 (1976).

[17] M. Mizumoto, N. Yamazoe, T. Seiyama, J. Catal. 59, 319 (1979).

[18] T. Komatsu, et al., J. Catal. 148, 427 (1994).

[19] S. Ham, H. Choi, I. Nam, Y. Kim, Catal. Lett. (1996).

[20] S. Kieger, G. Delahay, B. Coq, B. Neveu, J. Catal. 183, 267 (1999).

[21] G. Delahay, S. Kieger, N. Tanchoux, P. Trens, B. Coq, Appl. Catal., B 52, 251 (2004).

[22] K. Rahkamaa-Tolonen, T. Maunula, M. Lomma, M. Huuhtanen, R. L. Keiski, Catal. Today 100, 217 (2005).

[23] J. Park, et al., J. Catal. 240, 47 (2006).

[24] L. Olsson, H. Sjövall, R. J. Blint, Appl. Catal., B 81, 203 (2008).

[25] B. Moden, J. Donohue, W. Cormier, H. Li, Stud. Surf. Sci. Catal. 174, 1219 (2008).

[26] Y. Cheng, J. Hoard, C. Lambert, J. H. Kwak, C. H. Peden, Catal. Today 136, 34 (2008).

[27] H. Sjövall, R. J. Blint, L. Olsson, Appl. Catal., B 92, 138 (2009). 
[28] A. Palomares, F. Márquez, S. Valencia, A. Corma, J. Mol. Catal., A 162, 175 (2000).

[29] A. E. Palomares, J. Prato, A. Corma, Catal. Today 75, 367 (2002).

[30] A. Subbiah, et al., Appl. Catal., B 42, 155 (2003).

[31] A. E. Palomares, J. G. Prato, A. Corma, Ind. Eng. Chem. Res. 42, 1538 (2003).

[32] O. A. Anunziata, A. R. Beltramone, Z. Juric, L. B. Pierella, F. G. Requejo, Appl. Catal., A 264, 93 (2004).

[33] D. W. Fickel, E. D'Addio, J. a. Lauterbach, R. F. Lobo, Appl. Catal., B 102, 441 (2011).

[34] C. Franch-Martí, et al., J. Catal. 295, 22 (2012).

[35] M. Moliner, C. Franch, E. Palomares, M. Grill, A. Corma, Chem. Commun. 48, 8264 (2012).

[36] J. H. Kwak, R. G. Tonkyn, D. H. Kim, J. Szanyi, C. H. Peden, J. Catal. 275, 187 (2010).

[37] A. C. Gujar, G. L. Price, Microporous Mesoporous Mater. 54, 201 (2002).

[38] H. R. Angus, A. Stewart, Zeolites 10, 608 (1990).

[39] A. Stewart, Zeolites 9, 140 (1989).

[40] A. Stewart, D. Johnson, M. Shannon, Stud. Surf. Sci. Catal. 37, 57 (1988).

[41] A. Stewart, Zeolite synthesis, European Patent 0255770B1 (1987).

[42] J. H. Kwak, D. Tran, J. Szanyi, C. H. F. Peden, J. H. Lee, Catal. Lett. (2012).

[43] F. Gao, et al., J. Catal. 300, 20 (2013).

[44] J. M. Newsam, M. M. J. Treacy, W. T. Koetsier, C. B. D. Gruyter, Proc. R. Soc. London, Ser. A 420, 375 (1988). 
[45] P. a. Wright, W. Zhou, J. Pérez-Pariente, M. Arranz, J. Am. Chem. Soc. 127, 494 (2005).

[46] J. Hun Kwak, H. Zhu, J. H. Lee, C. H. F. Peden, J. Szanyi, Chem. Commun. 48, 4758 (2012).

[47] U. Deka, et al., J. Phys. Chem. C 116, 4809 (2012).

[48] F. Giordanino, et al., Dalton Trans. 42, 12741 (2013).

[49] J.-S. McEwen, et al., Catal. Today 184, 129 (2012).

[50] F. Göltl, R. E. Bulo, J. Hafner, P. Sautet, J. Phys. Chem. Lett. pp. 2244-2249 (2013).

[51] J. H. Kwak, et al., J. Catal. 287, 203 (2012).

[52] J. Pérez-Ramírez, F. Kapteijn, G. Mul, A. Moulijn, J. Catal. 208, 211 (2002).

[53] B. R. Wood, J. a. Reimer, A. T. Bell, M. T. Janicke, K. C. Ott, J. Catal. 224, 148 (2004).

[54] P. Smeets, et al., J. Catal. 245, 358 (2007).

[55] M. Mauvezin, G. Delahay, F. Kisslich, B. Coq, S. Kieger, Catal. Lett. 62, 41 (1999).

[56] U.S. Environmental Protection Agency, Health Assessment Document for Diesel Emissions (Draft), EPA/600/8-90/057C (Washington DC, 1998).

[57] H. Praliaud, S. Mikhailenko, Z. Chajar, M. Primet, Appl. Catal., B 16, 359 (1998).

[58] J. Petunchl, G. Sill, W. K. Hall, App. Catal., B 2, 303 (1993).

[59] F. Poignant, J. L. Freysz, M. Daturi, J. Saussey, Catal. Today 70, 197 (2001).

[60] C. He, Y. Wang, Y. Cheng, C. K. Lambert, R. T. Yang, Appl. Catal., A 368, 121 (2009).

[61] J. Li, R. Zhu, Y. Cheng, C. K. Lambert, R. T. Yang, Environ. Sci. Technol. 44, 1799 (2010). 
[62] L. Ma, J. Li, Y. Cheng, C. K. Lambert, L. Fu, Environ. Sci. Technol. 46, 1747 (2012).

[63] Q. Ye, L. Wang, R. T. Yang, Appl. Catal., A 427-428, 24 (2012).

[64] M.-J. Díaz-Cabañas, P. A. Barrett, Chem. Commun. pp. 1881-1882 (1998).

[65] E. a. Eilertsen, B. r. Arstad, M. H. Nilsen, K. P. Lillerud, Microporous Mesoporous Mater. 153, 94 (2011).

[66] J. F. M. Denayer, et al., J. Phys. Chem. C 112, 16593 (2008).

[67] E. M. Flanigen, R. W. Broach, S. T. Wilson, Zeolites in Industrial Separation and Catalysis (2010), chap. 1, pp. 1-26.

[68] B. Moden, J. M. Donohue, W. E. Cormier, H.-X. Li, Top. Catal. 53, 1367 (2010).

[69] D. W. Fickel, R. F. Lobo, J. Phys. Chem. C 114, 1633 (2010).

[70] L. Ren, et al., Chem. Commun. 47, 9789 (2011).

[71] I. Bull, et al., US. Patent 7,601,662 (2008).

[72] P. J. Anderson, H.-Y. Chen, M. Fedeyko, E. Weigert, US. Patent $7,998,443$ (2011).

[73] H.-X. Li, W. E. Cormier, B. Moden, US. Patent 7,883,678 (2011).

[74] P. T. Barger, Methanol Conversion Process Using SAPO Catalysts, U.S. Patent 5,095,163 (1992).

[75] U. Olsbye, et al., Angew. Chem. Int. Ed. 51, 5810 (2012).

[76] CasaXPS: Processing Software for XPS, AES, SIMS and More, http://www.casaxps.com (2013).

[77] T. Liese, W. Grünert, J. Catal. 172, 34 (1997).

[78] C. D. Wagner, W. M. Riggs, L. E. Davis, M. J. F., G. E. Muilenberg, Handbook of X-ray Photoelectron Spectroscopy (Perkin Elmer Corporation, Eden Prairie, Minnesota, 1979).

[79] M. Zema, S. C. Tarantino, G. Montagna, Chem. Mater. 20, 5876 (2008). 
[80] Z. Nour, H. Petitjean, D. Berthomieu, J. Phys. Chem. C 114, 17802 (2010).

[81] N. a. Ramsahye, R. G. Bell, Microporous Mesoporous Mater. 109, 405 (2008).

[82] N. a. Ramsahye, R. G. Bell, J. Phys. Chem.. B 109, 4738 (2005).

[83] E. Jaramillo, C. P. Grey, S. M. Auerbach, J. Phys. Chem. B 105, 12319 (2001).

[84] C. P. Grey, et al., J. Am. Chem. Soc. 119, 1981 (1997).

[85] J. Mortensen, L. Hansen, K. Jacobsen, Phys. Rev. B: Condens. Matter 71, 035109 (2005).

[86] J. Enkovaara, et al., Phys. Rev. B: Condens. Matter 22, 253202 (2010).

[87] S. Bahn, K. Jacobsen, Comput. Sci. Eng. 4, 56 (2002).

[88] G. Henkelman, H. Jonsson, J. Chem. Phys. 113, 9978 (2000).

[89] G. Henkelman, B. P. Uberuaga, H. Jonsson, J. Chem. Phys. 113, 9901 (2000).

[90] J. K. Nørskov, et al., J. Phys. Chem. B 108, 17886 (2004).

[91] S. Kurth, J. P. Perdew, P. Blaha, Int. J. Quantum Chem. 75, 889 (1999).

[92] E. Flanigen, R. Patton, S. Wilson, Stud. Surf. Sci. Catal. 37, 13 (1988).

[93] G. Sastre, D. W. Lewis, C. R. a. Catlow, J. Phys. Chem. B 101, 5249 (1997).

[94] L. Xu, et al., Microporous Mesoporous Mater. 115, 332 (2008).

[95] A. M. Prakash, S. Unnikrishnan, J. Chem. Soc., Faraday Trans. 90, 2291 (1994).

[96] M. Peltre, P. Man, M. Briend, Catal. Lett. 16, 123 (1992).

[97] M. H. W. Sonnemans, C. Den Heijer, M. Crocker, J. Phys. Chem. 97, 440 (1993).

[98] M. J. Rice, A. K. Chakraborty, A. T. Bell, J. Catal. 186, 222 (1999). 
[99] J. Dědeček, Z. Sobalík, B. Wichterlová, Catal. Rev. - Sci. Eng. 54, 135 (2012).

[100] S. Ashtekar, S. V. V. Chilukuri, D. K. Chakrabarty, J. Phys. Chem. 98, 4878 (1994).

[101] J. Tan, et al., Microporous Mesoporous Mater. 53, 97 (2002).

[102] X.-G. Wang, A. Chaka, M. Scheffler, Phys. Rev. Lett. 84, 3650 (2000).

[103] K. Reuter, M. Scheffler, Phys. Rev. B: Condens. Matter 65, 035406 (2001).

[104] P. Raybaud, J. Hafner, G. Kresse, S. Kasztelan, H. Toulhoat, J. Catal. 189, 129 (2000).

[105] M. Bollinger, K. Jacobsen, J. Nørskov, Phys. Rev. B: Condens. Matter 67, 085410 (2003).

[106] NIST Chemistry WebBook, http://webbook.nist.gov/chemistry/ (2013).

[107] J. a. Ryder, A. K. Chakraborty, A. T. Bell, J. Phys. Chem. B 104, 6998 (2000).

[108] H. Huo, L. Peng, C. Grey, J. Phys. Chem. C pp. 8211-8219 (2009).

[109] I. S. Afanassyev, N. K. Moroz, I. a. Belitsky, J. Phys. Chem. B 104, 6804 (2000).

[110] J. Kanellopoulos, et al., J. Catal. 255, 68 (2008).

[111] K. Krishna, M. Makkee, Catal. Today 114, 23 (2006).

[112] S. Brandenberger, O. Kröcher, M. Casapu, A. Tissler, R. Althoff, Appl. Catal., B 101, 649 (2011).

[113] R. Grinsted, H.-W. Jen, C. Montreuil, M. Rokosz, M. Shelef, Zeolites 13, 602 (1993).

[114] B. Palella, J. Catal. 217, 100 (2003).

[115] J. Yan, J. Catal. 161, 43 (1996).

[116] K. Kharas, H. Robota, D. Liu, Appl. Catal., B 2, 225 (1993). 
[117] T. Tanabe, et al., Appl. Catal., B 6, 145 (1995).

[118] A. Corma, J. Martinez-Triguero, S. Valencia, E. Benazzi, S. Lacombe, J. Catal. 206, 125 (2002).

[119] S. Lee, D. Lee, C. Shin, Y. Park, J. Catal. 215, 151 (2003).

[120] G. T. Palomino, et al., J. Phys. Chem. B 104, 4064 (2000).

[121] B. S. Clausen, H. Topsø e, Catal. Today 9, 189 (1991).

[122] B. Ravel, M. Newville, J. Synchrotron Radiat. 12, 537 (2005).

[123] N. Binsted, EXCURV98: CCLRC Daresbury Laboratory computer program (1998).

[124] H. Bremer, W. Morke, R. Schodel, F. Vogt, Adv. Chem. Ser (1973).

[125] T. Takaishi, Y. Yatsurugi, A. Yusa, T. Kuratomi, J. Chem. Soc., Faraday Trans. 71, 97 (1975).

[126] C. Prestipino, et al., Chem. Phys. Lett. 363, 389 (2002).

[127] C. Prestipino, et al., Chem. Mater. 18, 1337 (2006).

[128] C. Lamberti, et al., J. Phys. Chem. B 101, 344 (1997).

[129] W. B. Kim, E. D. Park, C. W. Lee, J. S. Lee, J. Catal. 218, 334 (2003).

[130] A. Zecchina, et al., J. Phys. Chem. 96, 4991 (1992).

[131] A. Zecchina, et al., J. Chem. Soc., Faraday Trans. 88, 2959 (1992).

[132] K. Barbera, F. Bonino, S. Bordiga, T. V. Janssens, P. Beato, J. Catal. 280, 196 (2011).

[133] B. Gil, Å. Mokrzycki, B. Sulikowski, Z. Olejniczak, S. Walas, Catal. Today 152, 24 (2010).

[134] M. K. Neylon, C. L. Marshall, A. J. Kropf, J. Am. Chem. Soc. 124, 5457 (2002).

[135] P. Da Costa, B. Moden, G. D. Meitzner, D. K. Lee, E. Iglesia, Phys. Chem. Chem. Phys. 4, 4590 (2002). 
[136] W.-P. Dow, Y.-P. Wang, T.-J. Huang, J. Catal. 160, 155 (1996).

[137] J. Rodriguez, J. Kim, J. Hanson, M. Pérez, A. Frenkel, Catal. Lett. 85, 247 (2003).

[138] S. Sato, M. Iijima, T. Nakayama, T. Sodesawa, F. Nozaki, J. Catal. 454, 447 (1997).

[139] G. Price, Catalyst Preparation: Science and Engineering, G. Ertl, H. Knözinger, F. Schüth, J. Weitkamp, eds. (Wiley-VCH Verlag GmbH \& Co. KGaA, Weinheim, Germany, 2008), pp. 283-296.

[140] C. E. Meyers, T. O. Mason, W. T. Petuskey, J. W. Halloran, H. K. Bowen, J. Am. Ceram. Soc. 63, 659 (1980).

[141] K. Jacob, C. Alcock, J. Am. Ceram. Soc. 58, 192 (1975). 
APPENDIX A

Publications

\section{List of publications included in the thesis}

- P.N.R. Vennestrøm, A. Katerinopoulou, R.R. Tiruvalam, A. Kustov, P.G. Moses, P. Concepcion, A. Corma, "Migration of $\mathrm{Cu}$ Ions in SAPO-34 and Its Impact on Selective Catalytic Reduction of $\mathrm{NO}_{x}$ with $\mathrm{NH}_{3}$ ", ACS Catal., 2013, 3, 2158

- P.N.R. Vennestrøm, T.V.W. Janssens, A. Kustov, M. Grill, A. Puig-Molina, L.F. Lundegaard, R.R. Tiruvalam, P. Concepcion, A. Corma, "Influence of lattice stability on hydrothermal deactivation of $\mathrm{Cu}-\mathrm{ZSM}-5$ and $\mathrm{Cu}-\mathrm{IM}-5$ zeolites for selective catalytic reduction of $\mathrm{NO}_{\mathrm{x}}$ by $\mathrm{NH}_{3}$ ", J.Catal., 2014, 309, 477

\section{Other publications}

- F. Giordanino, P.N.R. Vennestrøm, L.F. Lundegaard, F.N. Stappen, S. Mossin, P. Beato, S. Bordiga, C. Lamberti, "Characterization of Cu-exchanged SSZ-13: a comparative FTIR, UV- Vis, and EPR study with $\mathrm{Cu}-\mathrm{ZSM}-5$ and $\mathrm{Cu}-\beta$ with similar $\mathrm{Si} / \mathrm{Al}$ and $\mathrm{Cu} / \mathrm{Al}$ ratios", Dalton Trans., 2013, 42, 12741 
- M.M. Moliner, C.F. Marti, A.E. Palomares, A. Corma, P.N.R.

Vennestrøm, M. Grill, A. Kustov, J.R. Thøgersen, "Method and System for the Purification of Exhaust gas from an Internal Combustion Engine", European Patent Application PCT/EP2012/057795, 2012, pending

- S. Svelle, L. Sommer, K. Barbera, P.N.R. Vennestrøm, U. Olsbye, K.P. Lillerud, S. Bordiga, Y.-H. Pan, P. Beato, "How defects and crystal morphology control the effects of desilication", Catal. Today, 2011, 168, 38.

- P.N.R. Vennestrøm, C.M. Osmundsen, C.H. Christensen, E. Taarning, "Beyond petrochemicals: the renewable chemicals industry", Angew. Chem. Int. Ed., 2011, 50, 10502.

- P.N.R. Vennestrøm, M. Grill, M. Kustova, K. Egeblad, L.F. Lundegaard, F. Joensen, C.H. Christensen, P. Beato, "Hierarchical ZSM-5 prepared by guanidinium base treatment: Understanding microstructural characteristics and impact on MTG and $\mathrm{NH}_{3}-\mathrm{SCR}$ catalytic reactions", Catal. Today, 2011, 16871.

- K.T. Højholt, P.N.R. Vennestrøm, R. Tiruvalam, P. Beato, "Tight bifunctional hierarchical catalyst", Chem. Commun., 2011, 12864. 